POLÍTICAS PÚBLICAS DE SEGURIDAD Y FUNCIONES SOCIALES

MÓNICA LUCÍA AGUDELO CELY

UNIVERSIDAD SANTO TÓMAS

FACULTAD DE DERECHO

BOGOTÁ D.C. 2014 


\title{
POLÍTICAS PÚBLICAS DE SEGURIDAD Y FUNCIONES SOCIALES
}

\author{
Tesis \\ Presentada como requisito para optar por el título de Magister en Derecho Público \\ En la Facultad de Derecho \\ Universidad Santo Tomás
}

Presentada por:

MÓNICA LUCÍA AGUDELO CELY

Dirigida por:

Dr. SERGIO REYES BLANCO

Semestre I, 2015 


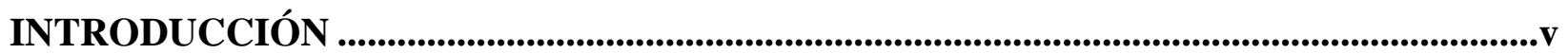

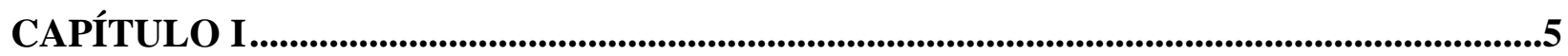

EL ESTADO SOCIAL DE DERECHO............................................................................5

UN MARCO JURÍDICO ...........................................................................................5

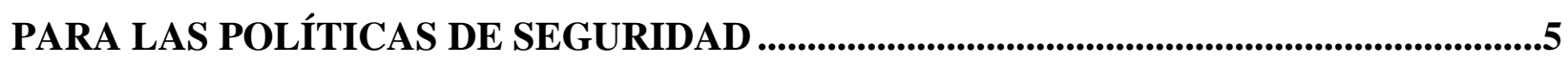

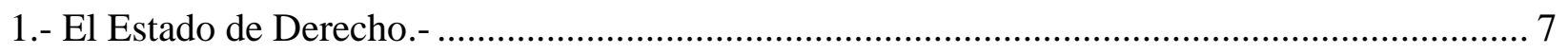

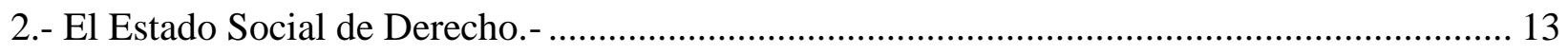

3.- El Estado Social de Derecho en la Constitución Colombiana.- ................................................. 22

4.- El Estado Social de Derecho de Colombia y la Seguridad.- .................................................. 28

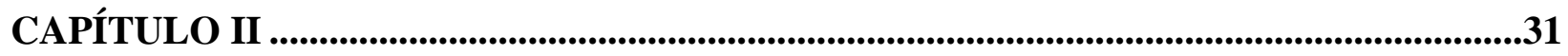

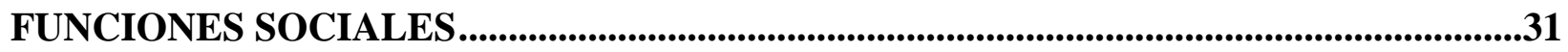

UN MARCO TEÓRICO PARA EL ANÁLISIS................................................................31

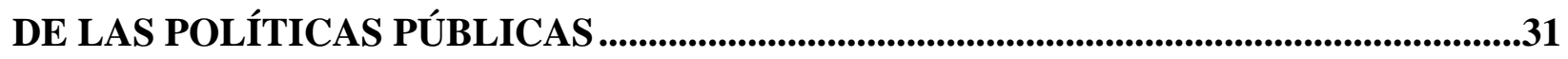

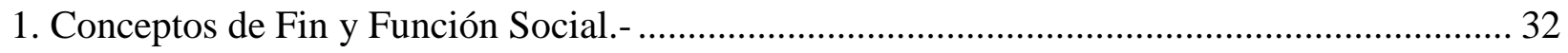

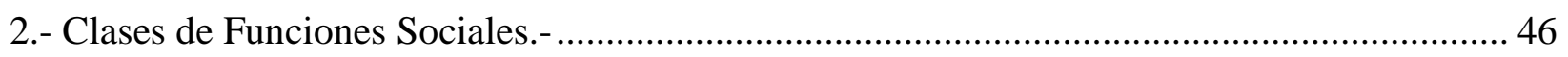

3.- La Metodología de Análisis Funcional y otras Categorías- ....................................................... 52

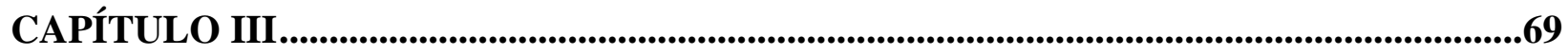

POLÍTICAS PÚBLICAS EN SEGURIDAD ...............................................................69

Y ANÁLISIS FUNCIONAL....................................................................................................................69

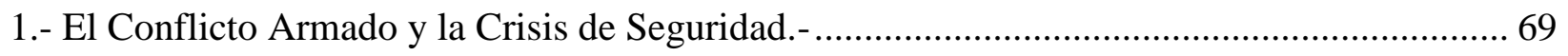

2.- Políticas Públicas en Seguridad y Funciones Sociales.-.......................................................... 91 


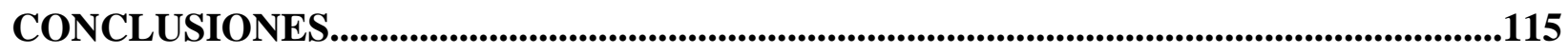

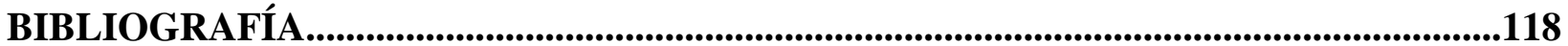

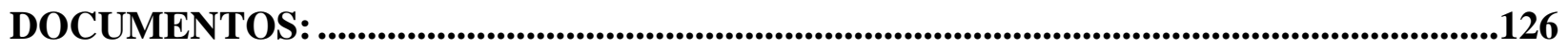




\section{INTRODUCCIÓN}

El presente trabajo gira en torno al tema de las políticas públicas de seguridad y las funciones sociales.

Las políticas públicas de seguridad pueden definirse como los instrumentos, concepciones, agencias, medidas, acciones u omisiones, que permiten la realización del control social, el cual a su vez, abarca el conjunto de instituciones, dispositivos y prácticas destinadas a preservar o imponer el orden y regular las relaciones sociales. Esto, para el caso colombiano, implica que se trata del orden preceptuado en la Constitución y que corresponde prioritariamente al Estado Social de Derecho, sin que ello pueda afectar la participación ciudadana en el desarrollo de estas políticas. En consecuencia, este tipo de políticas se encargan de regular y orientar la efectividad de los derechos fundamentales. El concepto de políticas públicas, además, es dinámico y flexible dado que enfrenta fenómenos cambiantes de conformidad con las condiciones sociales, culturales, políticas y económicas de una nación, incluso actualmente se ven afectadas por los procesos de globalización, lo cual significa que hay organismos internacionales y países extranjeros que inciden en el curso de dichas políticas.

En tanto funciones sociales, son las consecuencias sociales, los resultados, las repercusiones materiales, que pertenecen al ámbito del ser, pues se fundan en acciones o hechos sociales más no en decisiones o elecciones. Vale agregar, que no se trata de cualquier consecuencia, pues debe tratarse de aquella que tiene alguna significación social, es decir, que 
afecta a otras personas y, por lo mismo, puede instituirse en una abstracción teórica, con alguna capacidad de generalización.

El interés de realizar esta investigación es conocer, verificar y especificar si la política de seguridad desarrollada en las dos últimas administraciones, es decir, los dos gobiernos de Álvaro Uribe Vélez en los periodos comprendidos entre (2002-2006 y 2006-2010) y el periodo que corresponde al primer mandato presidencial de Juan Manuel Santos (2010-2014), cumplieron algunas funciones sociales y, en tal caso, cuáles, siguiendo el marco teórico del análisis funcional. Así mismo, se trata de analizar si las funciones sociales verificadas son respetuosas de los principios que se atribuyen al Estado social de derecho o si, por el contrario, vulneran dichos preceptos constitucionales.

Razón por la cual, este trabajo de tesis constituye una invitación a hacer un recorrido académico por tres capítulos, los cuales encierran los componentes del marco teórico que sirve de fundamento para el estudio, y que luego de edificar los pilares teóricos comprende el análisis propiamente dicho de las políticas de seguridad.

El primero de ellos, expone los lineamientos principales de la forma de organización estatal, pues la premisa que sirve de punto de partida sostiene que el modelo de organización estatal debe determinar el tipo de políticas públicas que se adoptan o, al menos, las formas jurídicas y políticas estatales deben servir como herramienta para hacer un examen crítico de las políticas de seguridad, en especial, los principios constitucionales y los derechos fundamentales. 
Comienza por la evolución del Estado liberal de derecho hasta llegar al Estado social de derecho, Estado de bienestar o como lo denominaron los ingleses Welfare State. El cual, supone la intervención del Estado en la propiedad privada y en la economía de los asociados, para propugnar por una situación de bienestar general que asegure el desarrollo de la persona humana, al igual que el respeto del ordenamiento jurídico, garantizar un mínimo vital en el sentido de asegurar unos ingresos mínimos que permitan al individuo vivir con dignidad y asumir las vicisitudes que se presenten como enfermedad, vejez, invalidez, desempleo, entre otras, pero siempre con respeto de la dignidad de la persona humana. Este camino conlleva la revisión de la norma superior que preceptúa los fines esenciales del Estado, dentro de los cuales, está servir a la comunidad, promover la prosperidad general, garantizar la efectividad de los principios, derechos y deberes consagrados en la Constitución, facilitar la participación de todos en las decisiones que los afectan, así como en la vida económica, política, administrativa y cultural de la Nación. Resulta igualmente importante atender el pronunciamiento de la Corte Constitucional, la cual ha indicado que en virtud del principio de la dignidad humana y el derecho a la paz, el Estado tiene el deber de prevenir la guerra y el conflicto armado interno a través de la adopción de unos mecanismos que faciliten espacios para su pacifica resolución, así como para su prevención.

A continuación, el segundo capítulo refiere la construcción de un marco teórico sobre las funciones sociales. Para realizar un análisis funcional de las políticas públicas de seguridad en Colombia, como se hará con posterioridad, debía iniciar por precisar la distinción entre fin y función, pues esta conceptualización envuelve confusiones en el ámbito del derecho y de la 
sociología. Es por ello que diferentes autores han estudiado el tema, han hecho sus aportes teóricos y han postulado definiciones alternativas o no de función social, partiendo de argumentaciones diferentes y desigualdades en sus enfoques teóricos. De ese modo, se estudiará a Robert K. Merton, uno de los más importantes exponentes del estructural funcionalismo, quien destacó la importancia teórica de la distinción entre fin y función. También, se aludirá a Luigi Ferrajoli, quien hizo hincapié en las desigualdades entre estos dos conceptos. Dicha distinción planteada por Merton y Ferrajoli es retomada por Germán Silva García para fabricar un concepto alternativo de función social, alejado del estructural funcionalismo. Para alcanzar mayor claridad teórica se continuará con el examen de los aportes de distintos autores al tema. Iván F. Pacheco, por ejemplo, acoge la distinción propuesta por Merton y agrega varios cuestionamientos. Roger Cotterrell cuestiona la tendencia a confundir estos conceptos amparando la diferencia entre los mismos. Vincenzo Ferrari, en cambio, recae en el yerro de perpetuar la confusión sobre fin y función, empero hace su aporte importante al análisis de las funciones sociales.

A efecto de potenciar el análisis funcional, Robert K. Merton propone una clasificación de las funciones sociales en manifiestas y latentes. Germán Silva García adhiere a la clasificación de Merton, pero agrega las simbólicas que fueron postuladas por Joseph R. Gusfield. De suerte que esta clasificación cumple el propósito de marcar diferencias entre aquello que se quiere o persigue y lo que en realidad acaece, lo cual será de mucha utilidad para realizar análisis concretos. Por su parte, Emiro Sandoval Huertas hablaba de las funciones declaradas y no declaradas o no reconocidas, nociones que serán igualmente revisadas para armonizarlas con el cuerpo teórico adoptado. 
Este capítulo también hace alusión al análisis funcional que implica una doble significación, en la medida en que puede entenderse como el método dirigido a la investigación, el estudio y examen crítico de los fenómenos sociales por una parte, y por otra, refiere la teoría sociológica o la filosofía social funcionalista. Vale decir, que el análisis funcional en cuanto a método de trabajo se encuentra íntimamente relacionado con aspectos de la teoría sociológica estructural funcionalista expuesta por Talcott Parsons, Robert K. Merton y otros teóricos. De modo muy distinto, autores como Vincenzo Ferrari, Norberto Bobbio, Iván F. Pacheco y Germán Silva García optan por utilizar el método de análisis funcional, a la vez que se apartan del estructural funcionalismo como doctrina de la filosofía social, lo que constituye precisamente la línea que se acoge en este trabajo.

Como método, el análisis funcional es un instrumento útil para examinar fenómenos sociales como las políticas de seguridad, ya que permite establecer cuáles son los fines de las políticas, si ellos son declarados o no declarados e identificar cuáles son las funciones sociales que se han verificado, al igual, que especificar si ellas son manifiestas, latentes o simbólicas.

Finalmente, el tercer y último capítulo abordará el conflicto armado interno. El cual, revisando la historia colombiana, indica que desde la década de los 60 surgen grupos al margen de la ley que se conforman en sus inicios, o pueden alcanzar altas cotas de desarrollo, como consecuencia del conflicto armado previo que se conoció como "La Violencia". Pero, además, sin duda esos origines históricos se vieron alentados de manera adicional por la exclusión social y política, la distribución desigual de las tierras, la destrucción del medio ambiente, la injusticia social y la desatención de los necesitados. 
Esa revisión de los antecedentes y características principales del conflicto armado interno tiene sentido, pues las políticas de seguridad buscan contrarrestarlo. En efecto, toda esta problemática motivo al gobierno nacional a darle prioridad y por supuesto a buscar mecanismos para erradicar la inseguridad, los secuestros extorsivos, el desplazamiento forzado, los homicidios, castigando el crimen y combatiendo la impunidad, lograr el respeto de los derechos humanos, y es en este punto en donde se advierte la necesidad de configurar las políticas de seguridad nacional.

Las políticas públicas de seguridad encuentran viabilidad en el Derecho Internacional Humanitario -DIH-, el cual, fue creado no para acabar la guerra, sino para hacerla más llevadera, haciendo que los objetivos políticos perseguidos sean logrados dentro de las mejores condiciones y se dé cumplimiento a finalidades humanitarias.

Capitulo que concluye con la especificación de las funciones sociales manifiestas, latentes y simbólicas verificadas en el desarrollo de la Política de Seguridad Democrática propuesta y ejecutada por el presidente Álvaro Uribe Vélez y la Política Integral de Seguridad y Defensa para la Prosperidad del presidente Juan Manuel Santos. Adicionalmente, se pudo evidenciar que algunas de ellas trasgreden y contravienen los principios del Estado Social de Derecho. 


\section{CAPÍTULO I}

\section{EL ESTADO SOCIAL DE DERECHO}

\section{UN MARCO JURÍDICO}

\section{PARA LAS POLÍTICAS DE SEGURIDAD}

El objeto de estudio del presente capítulo lo constituye en estricto sentido el Estado social de derecho, por lo que no se abordará el análisis de la teoría del derecho y del Estado y de las demás características que identifican al mismo, que para el caso colombiano se encuentran establecidas en el preámbulo y el artículo primero de la Constitución Política, aunque tangencialmente se hará relación a algunas de ellas.

Por consiguiente, se partirá de la doctrina tradicional según la cual el Estado es concebido como una organización que ejerce el poder soberano en un territorio determinado que constituye el ámbito espacial de validez del orden jurídico, al que están subordinados los sujetos que a él pertenecen. La existencia del mismo, en tanto al componente de "derecho" que acompaña la mención al Estado, se justifica en la medida en que representa la organización de las regulaciones que garantizan la seguridad jurídica, las cuales aseguran la aplicación y ejecución del ordenamiento normativo bajo el principio de legalidad. 
De otra parte, se concebirá al derecho como el instrumento del ser humano para organizar la vida política de las sociedades, teniendo en cuenta que desde los clásicos se encuentran varias consideraciones sobre el Derecho, entre las cuales cabe destacar las siguientes:

"La justicia es una necesidad social, porque el derecho es la regla de vida para la asociación política, y la decisión de lo justo es lo que constituye el derecho. Las buenas leyes no constituyen por sí solas un buen gobierno (...) lo que importa, sobre todo, es que estas leyes buenas sean observadas. No hay, pues, buen gobierno sino donde se obedece la ley, y donde la ley a que se obedece está fundada en la razón"1 . Es decir, se plantea una reivindicación de la justicia como fin superior del Derecho, sobre el cual descansa su legitimidad, y que a la vez es el valor fundamental de la profesión jurídica. Pero al tiempo se subraya la importancia de la eficacia del Derecho, en lo que la sociología jurídica bastante tiene que decir, puesto que al Derecho contemporáneo no le puede resultar satisfactorio, simplemente, el mero registro de un mandato en un precepto legal y luego desentenderse de su aplicación.

A lo que luego se agrega: "La república es la cosa del pueblo; y el pueblo no es el conjunto de todos los hombres reunidos de cualquier modo, sino reunidos por un acuerdo común respecto al derecho y asociados por causa de utilidad"2. Declaración que, a su vez, pone en cuestión el asunto de la democracia, de capital importancia.

En síntesis, y para asumir la doctrina de Santo Tomas de Aquino, el Derecho puede ser concebido como la manera racional para organizar civilizadamente a los miembros de una sociedad y limitar los poderes de un Estado. Lo anterior en tanto que la ley, como forma de

\footnotetext{
${ }^{1}$ Augusto Hernández Becerra. Las ideas políticas en la historia, Bogotá, Universidad Externado de Colombia, 1997, p. 73.

${ }^{2}$ Hernández Becerra. Ibíd., p. 102.
} 
expresión positiva del gobernante, debe promover el bien común, la paz, la justicia y la mayor libertad para todos; pero cuando la ley exceda sus límites, no obligará a la obediencia y se tornará nula ${ }^{3}$. Postura iusnaturalista que, en modo alguno, se opone a la concepción sobre el Estado social de derecho.

Así deslindados los dos conceptos, es necesario destacar que al Estado social de derecho, antecede el Estado de derecho como expresión de una férrea oposición a los Estados absolutista y totalitario, como se verá a continuación.

1.- El Estado de Derecho.-

En el Estado absolutista, el gobernante (monarca) tenía un carácter supremo y representa a toda la sociedad, por lo que a su arbitrio interpreta lo que considera como de interés general, además de establecer el orden jurídico a su antojo. El monarca ejerce el dominio directo sobre las propiedades y en consecuencia, en su poder radicar la facultad de expropiar cualquier bien sin indemnización. El Estado absolutista también se caracteriza por la concentración de los poderes esenciales del Estado: el legislativo, el ejecutivo y el judicial. Es así como el monarca adopta las decisiones de carácter general, se encarga de desarrollar las actividades ejecutivas y administrativas, y además, imparte justicia en su nombre.

\footnotetext{
${ }^{3}$ Hernández Becerra. lbíd., pp. 164 ss.
} 
En el Estado absoluto el poder, condensado en la noción de soberanía, es supremo, perpetuo e indivisible. Supremo porque no existe ningún poder en el mundo terrenal que se le pueda resistir, puesto que su único compromiso es ante Dios, de donde deriva sus atribuciones; perpetuo en razón a que su poder se prolonga hasta su muerte, después de la cual no tiene permanencia, sólo en razón a que el nuevo príncipe tiene a su vez un poder perpetuo; indivisible ya que concentra en sus manos las atribuciones de gobernar, legislar y juzgar ${ }^{4}$.

Por el contrario, en el Estado de derecho la organización de las instituciones políticas y de la sociedad dependía enteramente del mandato legal. "La ley aparece como el instrumento más adecuado para disponer una forma de sociedad y de estado" ${ }^{\prime 2}$ Así entonces, en el Estado de derecho, tanto la sociedad como el Estado deben estar sometidos al imperio de la ley. Así mismo, desde luego la división de los poderes públicos del Estado es un rasgo de su juridicidad, a fin de evitar la tiranía.

En términos generales, son dos los rasgos característicos del Estado de derecho: La supremacía de la ley y el principio de legalidad.

Con la supremacía de la ley, como expresión de carácter general, se buscaba que ningún gobernante podría estar por encima de ella. La ley como manifestación de la voluntad del pueblo, se oponía a cualquier intento absolutista de orden monárquico, donde la voluntad del gobernante se tornaba en el mandato para los gobernados.

\footnotetext{
${ }^{4}$ Las características del poder soberano fueron descritas por Jean Bodin. Los seis libros de la república, México D.F., Fondo de Cultura Económica, 1986, pp. 47 y ss.

${ }^{5}$ Camilo Velásquez Turbay. Derecho constitucional, Bogotá, Universidad Externado de Colombia, 1998, p. 283.
} 
De otra parte, pero complementario a lo anterior, el principio de legalidad pretendía ser un límite a la expresión del poder de los gobernantes, en tanto que "el poder público puede hacer lo que la ley le autorice, no puede dejar de hacer lo que le ordene la ley y no puede ir más allá de los límites que le fije la ley”“6 En contraposición al mencionado principio, los particulares podían hacer todo lo que no les esté expresamente prohibido.

Pero además de esa expresión filosófica del Estado, el Estado de derecho comporta también una determinada concepción política, que se instituye como la ideología liberal. De ahí que algunos autores identifiquen al Estado de derecho como el Estado democrático liberal ${ }^{7}$.

El liberalismo es la doctrina política que busca la efectividad de la libertad como valor superior y tiene como característica esencial, la de ser de corte individualista. Lo anterior implica que "el liberalismo considera que los valores individuales tienen supremacía sobre los colectivos, porque es el individuo el que hace su destino y hace la historia" ${ }^{\prime 8}$.

En ese entendimiento, el Estado liberal pretende la realización de la libertad con fundamento en tres medios: “1) Haciendo el reconocimiento solemne de los derechos individuales; 2) Dándole una organización a su poder en forma tal que se limite a sí mismo y garantice la vigencia de tales derechos, lo cual se ha llevado a cabo mediante la división de los

\footnotetext{
${ }^{6}$ Velásquez Turbay. Ibíd., p. 285.

${ }^{7}$ Eduardo Rozo Acuña. Introducción a las instituciones políticas. Bogotá, Gustavo Ibáñez, Sexta edición, 1998, p. 89.

${ }^{8}$ Jacobo Pérez Escobar. Derecho constitucional colombiano, 5aㅡ ed., Bogotá, Temis, 1997, p. 25.
} 
poderes; y 3) Sometiendo la actividad del Estado a normas jurídicas claras y precisas, para eliminar así todo peligro de arbitrariedad que pueda menoscabar esos derechos individuales"9.

Así entonces, al asociar el origen del Estado de derecho a la época de oposición a las monarquías absolutas, es posible advertir el punto de contacto con la ideología liberal, ya que como resultado de las revoluciones que surgieron en contra del régimen monárquico, además de instaurarse los derechos y libertades de los ciudadanos, se dio "el ascenso de la burguesía, clase social que asumiría progresivamente el liderazgo en las naciones europeas e impondría una forma propia de concebir el orden colectivo, económico y político"10.

Particularmente se pueden enunciar como características del Estado de derecho, las siguientes:

$\checkmark$ Tuvo su auge en el siglo XIX y parte del XX, además de lo cual contó con un valor referido a la eliminación de la arbitrariedad en el ámbito de la actividad estatal que afectaba a los ciudadanos.

$\checkmark$ Este tipo de Estado en su origen estuvo gobernado por la voluntad de la razón y orientado sólo a la consecución del mayor bien general.

\footnotetext{
${ }^{9}$ Pérez Escobar. lbíd., p. 26.

${ }^{10}$ Hernández Becerra. Las ideas políticas..., cit., p. 221.
} 
$\checkmark$ Tuvo como fundamento la exigencia de que el propio Estado determinara exactamente los cauces y límites de su actividad, así como la esfera de libertad de los ciudadanos conforme a derecho.

$\checkmark$ El Estado de derecho tenía una connotación sustantiva, relativa a las funciones y fines del Estado y en donde la ley empezaba a concebirse como instrumento de garantía de los derechos.

$\checkmark$ Parte de la concepción de la ley como acto deliberado de un parlamento representativo, concretado en: 1. La supremacía de la ley; 2. La subordinación a la ley de los derechos de los ciudadanos. 3. La presencia de jueces independientes con competencia exclusiva para aplicar la ley a las controversias surgidas.

$\checkmark$ Igualmente es característico del Estado de Derecho, el modo en que se instituye la línea de separación entre Estado y ciudadanos, pues la ley no establecía lo que la administración no podía hacer, sino lo que podía, mientras que para los particulares regía el principio de autonomía, siempre que no se traspasara el límite de la ley.

$\checkmark$ La ley no es una norma que deba ser ejecutada simplemente, sino respetada como límite externo de la autonomía contractual; a la ley se le reconoce superioridad frente a todos los demás actos jurídicos. 
De otra parte, como expresión histórica que surge del Estado moderno, en la época también es posible identificar el origen del Derecho constitucional, pues éste se apoya en el "compromiso de la civilización política empeñada en sustituir la monarquía o los poderes monárquicos en los países de la Europa continental, que se refleja, en cuanto realidad política, en la desaparición de las relaciones colonialistas surgidas en desarrollo de la praxis de aquella forma de gobierno, y de las relaciones de dominio propias de la estructura colonial" ${ }^{11}$.

De esta manera, a partir de entonces, se puede mencionar que el principio característico del Estado de derecho que se concreta en la supremacía de la ley, implica necesariamente el reconocimiento de la Constitución como ley superior que delimita y controla el poder, regula y organiza el Estado y reconoce los derechos y libertades de los ciudadanos, y se estructura así como sistema de dominación política. ${ }^{12}$

En efecto, la Constitución se concibe como el orden jurídico fundamental del Estado, o como el orden jurídico fundamental de la comunidad, al que se atribuye un rango especial, frente a las leyes y al resto de las fuentes del derecho, y un efecto de irradiación sobre todas las ramas del ordenamiento jurídico.

Con el Derecho constitucional en la época moderna, la ley viene sometida a una relación de adecuación y por tanto de subordinación a un estrato más alto, esto es, a la Constitución.

\footnotetext{
${ }^{11}$ Velásquez Turbay. Derecho..., cit., p. 25.

12 Pablo Lucas Verdú. Curso de derecho político. Madrid, Tecnos, 1984, p. 40 a 49 y 191 a 202.
} 
Así, lo que caracteriza al Estado Constitucional actual, es la separación entre los distintos componentes del derecho que en el Estado de Derecho del siglo XIX estaban reducidos en la ley. $^{13}$

2.- El Estado Social de Derecho.-

Con la Constitución Federal de los Estados Unidos de 1787 y la Declaración de los Derechos del Hombre y del Ciudadano en Francia en 1789, se oficializa el origen del constitucionalismo.

En lo que respecta a la Constitución que rige a los Estados Unidos de América desde 1787, se advierte que no solo es la más antigua de las constituciones escritas, sino que además incorpora por primera vez principios de convivencia social y de gobierno.

Por su parte, la Declaración de los Derechos del Hombre y del Ciudadano, asegura un margen de libertades y garantías individuales, en la medida que la libertad, la propiedad, la seguridad y la resistencia a la opresión se instituyen como derechos naturales e imprescriptibles del ser humano. Garantiza la igualdad ante la ley así como la libertad de comunicación de los pensamientos y de las opiniones, y en consecuencia, nadie puede ser molestado por la expresión

${ }^{13}$ Gustavo Zagrebelsky, El derecho dúctil, Madrid, Trotta. 1995, pp. 21 ss. 
de las mismas. Además, mediante la separación orgánica y funcional del poder, asegura el respeto de tales derechos por parte de quien lo detenta.

La separación de poderes implica que "al no estar concentrado el poder en las manos de un solo gobernante, el gobernado puede recurrir para su protección a los otros funcionarios o representantes del poder. Ante leyes o decisiones legislativas, los ciudadanos pueden recurrir a la rama judicial cuando crean que no son justas, ilegales, inconstitucionales o que lesionan sus derechos y libertades. De la misma manera pueden actuar frente a decisiones ejecutivas y pueden recurrir también a sus representantes en los órganos legislativos para la derogación de las leyes que no correspondan a sus intereses y para la elaboración de las que los favorezcan ${ }^{14,}$.

No obstante, el logro alcanzado con el reconocimiento de las libertades individuales, al compás de las revoluciones sociales surgía también la revolución industrial y, con ella, la transformación de los procesos de producción, el cambio en las condiciones de vida y trabajo y la acumulación de riquezas privadas, que acentuaban las desigualdades entre dos clases sociales: la burguesía y el proletariado; ésta última, sometida a condiciones de vida y trabajo inhumanos, al padecimiento de hambre y miseria, que dan origen a las doctrinas socialistas para reclamar del Estado la intervención en procura de sus derechos.

En efecto, "bajo la presión de los movimientos obreros, de los problemas sociales creados por la Gran Guerra y las necesidades expansivas de la industrialización, el Estado liberal de derecho, individualista y abstencionista, se ve precisado a adaptar sus instituciones jurídicas y políticas a los nuevos requerimientos del desarrollo técnico, social y económico. Evoluciona

${ }^{14}$ Rozo Acuña. Introducción..., cit., p.87. 
entonces hacia el Estado social de derecho, que morigera el individualismo clásico liberal mediante la incorporación de los llamados derechos sociales, el compromiso del Estado con objetivos de justicia social y la adaptación del aparato administrativo para garantizar los derechos sociales mediante una vigorosa intervención en la vida económica de los asociados"15.

El socialismo mantiene la creencia de que solo a través de un Estado, de un orden coercitivo, podrá arrebatar a los capitalistas la posesión de los medios de producción. El proletariado convertido en clase dominante, utilizaría el poder político para desposeer progresivamente a los capitalistas privados de los medios de producción, transfiriéndolos al Estado, esto es, usaría el poder político para estatalizar la tierra y las edificaciones, los medios de transporte, las minas y así gradualmente hasta que todo el proceso de producción esté dirigido por el Estado.

En ese orden de ideas, el socialismo, ataca el concepto formal del Estado de derecho porque había consolidado y reforzado la posición económica de la burguesía. El socialismo no quiere entonces darle prioridad al mantenimiento de los derechos de libertad propios del Estado democrático de derecho, puesto que prefiere que prevalezca la igualdad social, económica y política, sobre las libertades. Esa igualdad material, a diferencia de la igual formal del Estado liberal, deberá alcanzarse mediante la dictadura del proletariado. Apenas, con la evolución del pensamiento socialista, cuando abandona las lecturas del marxismo leninismo, renunciando a la dictadura del proletariado, es decir, cuando ese socialismo plantea como una forma de socialdemocracia, viene a identificarse con el Estado social de derecho. Pero, para entonces, además, llega a plantear que el Estado de derecho debe abrirse a las exigencias de la democracia

${ }^{15}$ Hernández Becerra. Las ideas políticas..., cit., p. 334. 
social, para que mediante la intervención estatal pueda perseguirse la construcción de una organización basada en la igualdad material, económica y social, convirtiéndose de esa manera la organización estatal en un Estado social de derecho.

El Estado social representa, en consecuencia, el intento de adaptación del Estado liberal tradicional a las condiciones sociales de la civilización industrial y post-industrial. Y por consiguiente, el Estado social de derecho comporta dos elementos ideológicos que se tratan de armonizan: los propios del Estado liberal y los del Estado social. En pocas palabras, se trata de proveer de articulación a las libertades individuales y, por otra parte, a la igualdad material y al bienestar social de la colectividad.

El carácter social del Estado puede ser considerado "bien como una reacción contra la injusticia social, bien como una forma histórica determinada de la sociedad o bien como doctrina política" ${ }^{" 16}$. En términos generales, aunque se han distinguido varias clases de socialismo, se ha afirmado que todos tienen en común la intervención sobre la propiedad privada (que no necesariamente su abolición), por ser la fuente de todas las desigualdades e injusticias sociales ${ }^{17}$. El socialismo surge entonces como una opción para lograr la justicia social.

Además, el Estado social se acoge a la legitimidad democrática y junto a esta legitimidad democrática introduce una nueva, la de la eficacia. En este contexto, el Estado social asume la responsabilidad de impedir los desequilibrios sociales y pasa a tener una importante tarea frente a la redistribución de las rentas. Tal circunstancia le da legitimidad entre las masas, a las que

\footnotetext{
${ }^{16}$ Pérez Escobar, Derecho..., cit., p. 28

${ }^{17}$ Pérez Escobar, Ibíd., p. 29.
} 
asegura mínimos de subsistencia y bienestar, imponiéndole también responsabilidades y riesgos ${ }^{18}$.

Es así como en las Constituciones de México de 1917 y de Alemania de 1919 se incorporan a la declaración de derechos hasta el momento imperante, los derechos de contenido social. Por su parte, la acción de los partidos socialistas, el auge industrial y las ideas económicas de John Maynard Keynes, conducen al intervencionismo del Estado para la garantía de los derechos sociales, la intervención en la economía y la garantía del empleo.

Lo anterior conlleva a la consolidación de la administración pública para que satisfaga las necesidades de los ciudadanos mediante la prestación de bienes y servicios.

Es importante resaltar que la formulación de la idea del Estado Social de Derecho, como es de amplio conocimiento, se le debe a Hermann Heller, quien se enfrenta con el problema concreto de la crisis de la democracia y del Estado de derecho, al que considera que es preciso salvar de la dictadura fascista, de la decadencia del positivismo jurídico y los intereses de los estatutos dominantes. En este sentido, el Estado social puede ser una alternativa frente a la anarquía económica y frente a la dictadura fascista y puede además ser la vía política para salvar los valores de la civilización.

El interés del Estado social de derecho consiste en crear una situación de bienestar general que garantice el desarrollo de la persona humana y respete el ordenamiento

\footnotetext{
${ }^{18}$ Remedios Sánchez Ferriz. Introducción al Estado Constitucional, Barcelona, Ariel, 1993, pp. 139 a
} 181. 
jurídico. Ahora bien, las necesidades sociales exigen una amplia máquina administrativa y requieren de abundante legislación para lograr la justicia social, sin que se degenere en plétora legislativa. ${ }^{19}$ Esto conduce al desarrollo de la figura del estado intervencionista, que se asocia al Estado social de derecho.

En síntesis, aunque conceptualmente el Estado haya sido en sus orígenes un poder representativo de toda la sociedad o un producto del contrato social entre todos los individuos convertidos de esta manera en ciudadanos, el Estado sigue siendo un Estado de derecho, esto es, un Estado garantista de los derechos del individuo frente al poder y frente a los demás ciudadanos, pero es también un Estado social, es decir, un Estado comprometido con la promoción del bienestar de la sociedad y de manera muy especial, con la de aquellos sectores más desfavorecidos de la misma.

En definitiva, el Estado Social es una consecuencia del proceso de democratización del Estado, en la medida en que el Estado tiene que atender y dar respuesta a las demandas de todos los sectores de la sociedad. ${ }^{20}$

Hoy todos los Estados industrializados son organizaciones estatales de índole social, con sistemas desarrollados de prevención social, de enseñanza pública generalizada, con intervención

19 Pablo Lucas Verdú. Estado Liberal Derecho y Estado Social de Derecho. T. II, Universidad de Salamanca, 1955, pp. 75 a 80.

20 Javier Pérez Royo. Curso de derecho constitucional, $2^{\underline{a}}$ ed., Madrid, Marcial Pons, 1995, pp. 187 a 213,765 a 781. 
importante en el mundo de la economía, enriquecidos en gran medida tanto por la doctrina del Estado de derecho y el Estado liberal, como por la del Estado de bienestar o Welfare State. ${ }^{21}$

En efecto, los ingleses acogieron la denominación alemana de Estado Bienestar e introdujeron el concepto de Welfare State, como un modelo que procura el bienestar de todos los ciudadanos, garantizando ingresos mínimos que aseguren vivir con dignidad en las vicisitudes que se presenten como enfermedad, invalidez, vejez, desempleo y acepta la diferencia en las prestaciones de estos servicios pero con respeto de la dignidad humana. El logro más destacado de todo el Estado bienestar británico fue el servicio nacional de salud y el servicio sanitario gratuito, aunque en los últimos decenios se han añadido al Estado otras finalidades esenciales, como el cuidado de las personas dependientes y el derecho a una vivienda digna.

Otro acierto es que garantiza un mínimo vital con lo que queda eliminada la pobreza absoluta, identificada con el hambre, en el sentido literal de no tener nada que llevarse a la boca, aunque se mantenga un concepto de pobreza relativa, en tanto que depende del grado de desarrollo económico y social alcanzado por cada individuo. De tal manera, que la pobreza se mantiene como un concepto relativo a la vez que multidimensional, porque no consiste en una falta de dinero para cubrir las necesidades básicas, sino que incluye una privación en salud, vivienda, educación, etc., e implica la no participación en áreas importantes de la vida social.

Así enriquecidos los fines esenciales del Estado, éste se constituye como una institución en defensa de los intereses de los ciudadanos, de su honor y bienes, así como en garante de la seguridad y la paz, mediante el respeto irrestricto de la Constitución como ley suprema.

${ }^{21}$ Elías Díaz. Estado de Derecho y Sociedad Democrática. 8ª ed., Madrid, Taurus. 1981, pp. 83 a 111. 
Es entonces de esa manera como el Estado social de derecho se ha estatuido en las constituciones de los diferentes países; así por ejemplo la Constitución española de 1978, en la línea de la ley fundamental de Bonn, la constitución establecía que España se constituía como un Estado social y democrático de derecho. De igual manera las constituciones de Venezuela, aprobada en 1999, de Ecuador, aprobada en 2008 y de Bolivia de 2009, pretendían generar un vínculo de complementariedad entre constitucionalismo y democracia, y se adopta la forma de Estado social, pero no se consagra una económica social de mercado, se trata de una economía social solidaria y plural, en la que el alcance del mercado viene limitado por la importancia dada a la noción de planificación democrática o al rechazo de prácticas sociales basadas en la especulación o la explotación ${ }^{22}$.

Así entonces, la Constitución de un Estado comprende no solo las normas jurídicas que regulan los órganos del Estado, su formación, la competencia y las relaciones mutuas, sino el status básico en el que se encuentra el individuo frente al Estado y lo dota de órganos que le facultan para querer y para actuar, dándole a través de ellos una personalidad jurídica.

La Constitución también dota de garantía plena a los derechos fundamentales, al exigir que la regulación del ejercicio de los mismos se realice forzosamente por la ley, impidiendo que otro órgano que no sea el legislativo, proceda a la regulación de las condiciones de ejercicio de los derechos fundamentales (reserva de la ley).

${ }^{22}$ Gerardo Pisarello. La ofensiva oligárquica y la lucha por la constitución democrática. Un largo termidor. La ofensiva del constitucionalismo antidemocrático, Madrid, Trotta, 2011, pp. 169 a 212. 
Además, la Constitución prevé unos mecanismos específicos de tutela de los derechos fundamentales en los casos en que puedan resultar vulnerados, a través de un procedimiento basado en los principios de preferencia y sumariedad.

Se habla entonces de la llegada del neoconstitucionalismo que supone que los ordenamientos jurídicos contemporáneos estén impregnados de normas constitucionales ${ }^{23}$. En consecuencia, los poderes legislativos y de gobierno están jurídicamente limitados por los preceptos constitucionalmente establecidos, que se instituyen como garantías.

El concepto de garantías designa las prohibiciones o las obligaciones correspondientes a las expectativas positivas o negativas normativamente establecidas, en forma de derechos subjetivos. Son garantías negativas las prohibiciones correspondientes a expectativas negativas, como todos los derechos a no ser lesionados por otros, del derecho real de propiedad a los derechos de libertad y al derecho a la vida; son garantías positivas, las obligaciones correspondientes a expectativas positivas, como todos los derechos o prestaciones de otros, de los derechos de crédito, entre otros ${ }^{24}$.

En este sentido, en el marco constitucional se produce una ampliación de derechos colectivos, sociales, de grupos, de trabajadores, de desvalidos, de las clases medias, de las

\footnotetext{
${ }^{23}$ Miguel Carbonell. Neoconstitucionalismo y Derechos Fundamentales, Quito, Cevallos. 2010, pp. 48 y SS.

${ }^{24}$ Luigi Ferrajoli. Poderes Salvajes. La crisis de la democracia constitucional, Madrid, Trotta 2011, pp. 27 y ss.
} 
minorías étnicas, religiosas y culturales, dando paso de esta manera al surgimiento de las funciones sociales del Estado ${ }^{25}$.

\section{3.- El Estado Social de Derecho en la Constitución Colombiana.-}

En el preámbulo de la Constitución se enuncia las fuentes y principios que motivaron la reforma en 1991 bajo una idea de Estado social de derecho que garantizara a las personas la vida, la convivencia, el trabajo, la justicia, la igualdad, el conocimiento, la libertad y la paz ${ }^{26}$. Luego en el artículo primero se estatuye como principio fundamental del Estado social de derecho que está fundado en el respeto de la dignidad humana, en el trabajo y la solidaridad de las personas que la integran y en la prevalencia del interés general. ${ }^{27} \mathrm{El}$ artículo segundo proclama los fines esenciales del Estado, entre los cuales se encuentran: servir a la comunidad, promover la prosperidad general y garantizar la efectividad de los principios, derechos y deberes consagrados en la Constitución; facilitar la participación de todos en las decisiones que los afectan y en la vida económica, política, administrativa y cultural de la Nación; defender la independencia nacional, mantener la integridad territorial y asegurar la convivencia pacífica y la vigencia de un orden justo. Además establece que las autoridades de la República están instituidas para proteger a todas las personas residentes en Colombia, en su vida, honra, bienes,

\footnotetext{
${ }^{25}$ Luis Carlos Sáchica. Derecho Constitucional General, Bogotá, Temis, 1999, p. 220.

${ }^{26}$ Corte Constitucional. Sentencia C - 107 de 2001, Magistrada Ponente Clara Inés Vargas Hernández. ${ }^{27}$ Corte Constitucional. Sentencia C - 336 de 2008, Magistrada Ponente Clara Inés Vargas Hernández.
} 
creencias, y demás derechos y libertades, y para asegurar el cumplimiento de los deberes sociales del Estado y de los particulares.

Por su parte, el artículo 64 dispone que es deber del Estado promover el acceso progresivo a la propiedad de la tierra de los trabajadores agrarios, en forma individual o asociativa, y a los servicios de educación, salud, vivienda, seguridad social, recreación, crédito, comunicaciones, comercialización de los productos, asistencia técnica y empresarial, con el fin de mejorar el ingreso y calidad de vida de los campesinos.

Según la Corte Constitucional, "la fórmula del artículo primero de la Constitución, ampliada y respaldada a través de todo el texto fundamental, según la cual Colombia se define como un Estado social de derecho, es de una importancia sin precedentes en el contexto del constitucionalismo colombiano...Lo primero que debe ser advertido es que el término "social", ahora agregado a la clásica fórmula del Estado de Derecho, no debe ser entendido como una simple muletilla retórica que proporciona un elegante toque de filantropía a la idea tradicional del derecho y del Estado. Una larga historia de transformaciones institucionales en las principales democracias constitucionales del mundo, está presente para dar testimonio de la trascendencia de este concepto, 28 .

Bajo estos preceptos el Estado Social de Derecho no puede entenderse como una formula retórica, sino como aquel que tiene como meta que los presupuestos materiales de libertad y de igualdad estén asegurados para todos a través de acciones y servicios. ${ }^{29}$

\footnotetext{
${ }^{28}$ Corte Constitucional. Sentencia T - 406 de 1992, Magistrado Ponente Ciro Angarita Barón.

${ }^{29}$ Manuel Aragón Reyes. Constitución y Democracia, Madrid, Tecnos, 1989.
} 
De otra parte, la figura del Estado Social de Derecho predica una igualdad real, material o sustancial, la cual, debe guiar la actividad estatal con el propósito de enmendar las desigualdades existentes, asegurar la igualdad de oportunidades, la nivelación social, procurar la efectividad de los derechos fundamentales de las personas, al igual, que promover la inclusión y la participación de todos en las decisiones que los afectan, adoptar medidas a favor de grupos marginados o discriminados, proteger a las personas que por su condición económica, física o mental se encuentren en circunstancias de debilidad manifiesta (artículo 13 inciso 2 C.P.); proteger a la mujer cabeza de familia, embarazada, a la niñez, a los adolescentes, a las personas de la tercera edad, a los discapacitados, a los pensionados y enfermos (artículos 43 a 49 C.P.). ${ }^{30}$

Además, el Estado Social de Derecho se desarrolla en torno a tres principios orgánicos: la legalidad, independencia y colaboración de las ramas del poder público para la consecución de los fines esenciales del Estado. ${ }^{31}$ (Artículos $2^{\circ}, 3^{\circ}, 113,365$ y 366 de la Constitución).

Así mismo, la consagración del Estado social de derecho conlleva a considerar el trabajo, ya sea que se trate de una actividad independiente o subordinada, como un derecho fundamental que goza de especial protección por parte del Estado, por ser un factor básico de la organización social, un principio axiológico de la Carta, una actividad libre y lícita del hombre que aporta al desarrollo y dignificación personal, así como al progreso de la sociedad y finalmente contribuye a la construcción de la legalidad. ${ }^{32}$

\footnotetext{
${ }^{30}$ Corte Constitucional. Sentencia C- 1064 de 2001, Magistrado Ponente Manuel José Cepeda Espinosa y Jaime Córdoba Triviño.

31 Corte Constitucional. Sentencia C - 449 de 1992, Magistrado Ponente Alejandro Martínez Caballero.

${ }^{32}$ Corte Constitucional. Sentencia SU - 636 de 2003. Magistrado Ponente Jaime Araujo Rentería.
} 
Es por ello que el Estado debe apoyar a los desempleados incluso por medio del "subsidio de desempleo", que el legislador dando cumplimiento a este mandato constitucional diseñó para aquellas personas que están en capacidad de trabajar, pero que se ven excluidas del mercado laboral por la precariedad del aparato económico de este país, así como promover el pleno empleo y el mejoramiento de la calidad de vida de las personas de menores ingresos (artículo 334, inciso 2 C.P.); asignar el gasto social para satisfacer las necesidades insatisfechas en educación, salud, saneamiento ambiental, agua potable (artículo 366 C.P.); subsidiar los servicios públicos domiciliarios (art. $368 \mathrm{CP}$ ); promover la protección de los más débiles, es decir, aquellos que se encuentren en situaciones de miseria o indigencia, cuya carencia de recursos y capacidades productivas los colocan en situaciones de manifiesta marginalidad, debilidad y vulnerabilidad.

La cláusula del Estado Social de Derecho le asigna competencias al legislador, le impone a la administración la responsabilidad de la gestión, vigilancia, control y prestación de los servicios públicos, convierte los procesos de planificación económica, diseño y ejecución del presupuesto, descentralización y autonomía territorial, en oportunidades institucionales para fijar el alcance del Estado servicial y de los medios financieros y materiales destinados a su realización, abre espacio para la participación de los ciudadanos beneficiarios de estos servicios, asume funciones relacionadas con los procesos sociales, políticos y jurídicos; le otorga un papel preponderante a la voluntad democrática porque es la encargada de concretar los hechos de la vida social y política. ${ }^{33}$

${ }^{33}$ Corte Constitucional. Sentencia SU - 747 de 1998. Magistrado Ponente Eduardo Cifuentes Muñoz. 
En consecuencia, el Estado Social de Derecho coacciona al legislador para que responda a los criterios de justicia y equidad constitucional, en la toma de sus decisiones y políticas públicas. $^{34}$

De otra parte, el Estado social de derecho en la Constitución Política, tiene como presupuestos básicos los principios de dignidad humana, de solidaridad social, promover la prosperidad general y garantizar la efectividad de los derechos, deberes y principios constitucionales y el derecho fundamental a la igualdad de oportunidades, los cuales, tienen por función guiar la interpretación de la constitución económica normativizando los conceptos de propiedad privada, libertad de empresa, explotación de recursos, producción, distribución, utilización y consumo de bienes y servicios, régimen impositivo, presupuestal y de gasto público. ${ }^{35}$

Adicionalmente, el Estado social de derecho supone la participación ciudadana y la contribución al fisco para poder exigir del Estado la prestación de determinados servicios; ${ }^{36}$ el Estado debe planear la panificación del presupuesto en los distintos niveles territoriales y funcionales del Estado y atender en todo momento la participación ciudadana so pena de caer en un Estado totalitario. ${ }^{37}$

El Estado social de derecho debe cimentar las circunstancias indispensables que garanticen a los ciudadanos una vida digna dentro de las posibilidades económicas que estén a su

\footnotetext{
${ }^{34}$ Corte Constitucional. Sentencia C- 1064 de 2002, Magistrado Ponente Manuel José Cepeda Espinosa y Jaime Córdoba Triviño.

${ }_{35}$ Corte Constitucional. Sentencia T-505 de 1992, Magistrado Ponente Eduardo Cifuentes Muñoz.

${ }^{36}$ Corte Constitucional. Sentencia C-566 de 1995, Magistrado Ponente Eduardo Cifuentes Muñoz.

${ }^{37}$ Corte Constitucional. Sentencia SU - 111 de 1997, Magistrado Ponente Eduardo Cifuentes Muñoz.
} 
alcance, al igual que la libertad, la igualdad y la realización efectiva de los derechos de los individuos que conforman la sociedad. ${ }^{38}$

El contenido humanitario es también una de las características primordiales del Estado social de derecho; es por ello, que la asistencia social debe brindarse en todo instante. El constitucionalismo ha reconocido el derecho a la vida, preocupándose no sólo por garantizar la existencia biológica, sino por elevar cada vez más el alcance de la dignidad de la persona humana, expresando de esta manera el carácter de inviolabilidad de la vida humana como derecho. ${ }^{39}$

El Estado social de derecho propugna además por el reconocimiento y respeto de la dignidad de la persona humana y el libre desarrollo de la personalidad, en la medida en que busca la protección eficaz de la persona, concebida como la razón de ser de la estructura socio-política, así como procurar el logro de los derechos que le son inherentes. En consecuencia, se imponen nuevos deberes al Estado, como el de facilitar las condiciones materiales e inmateriales para el desarrollo del proyecto de vida del individuo o cuando interactúa con otras personas apareciendo de esta forma, nuevos valores intrínsecos del ser humano. ${ }^{40}$

De igual manera, la dignificación de la persona humana, comporta para el Estado tener como prioridad mitigar las penurias económicas, sociales y las desventajas en los diferentes sectores de la población, garantizando las condiciones económicas y espirituales a través de la

\footnotetext{
${ }^{38}$ Corte Constitucional. Sentencia No. T-571 de 1992, Magistrado Ponente Jaime Sanín Greiffenstein.

${ }^{39}$ Corte Constitucional. Sentencia T-513 de 1995, Magistrado Ponente Vladimiro Naranjo Mesa.

${ }^{40}$ Corte Constitucional. Sentencia C - 288 de 2012, Magistrado Ponente Luis Ernesto Vargas Silva.
} 
protección y asistencia que requieran para la materialización y efectividad de los derechos en mención, a fin de lograr una organización política, económica y social justa ${ }^{41}$.

En síntesis, al Estado Social de Derecho irradia todo el ordenamiento jurídico así como las actuaciones administrativas del gobierno, en tanto que le interesa el mejoramiento de la calidad de vida de los ciudadanos, atendiendo de esta forma a un nuevo humanismo, a la tridivisión de poderes, la soberanía popular, la legalidad y a un poder controlado. ${ }^{42}$

4.- El Estado Social de Derecho de Colombia y la Seguridad.-

La función más antigua y específica del Estado es la defensa del territorio contra todo ataque exterior. Ésta, al igual que la protección de la comunidad, deben entenderse como fines de todo Estado, en tanto que garantizan la conservación de sí mismo y principalmente la seguridad e integridad de sus habitantes.

Como se mencionó antes, desde la Declaración de los Derechos del Hombre y del Ciudadano, se estableció que la conservación de los derechos entre los cuales se encuentra la seguridad y la propiedad, es el fin de toda asociación política.

${ }^{41}$ Corte Constitucional. Sentencia T - 426 de1992, Magistrado Ponente Eduardo Cifuentes Muñoz.

42 Corte Constitucional. Sentencia C - 566 de 1995, Magistrado Ponente Eduardo Cifuentes Muñoz. 
Así lo previó el constituyente colombiano, en la medida que en el inciso segundo del artículo segundo de la Constitución Política se dispuso que las autoridades de la República están instituidas para proteger a todas las personas residentes en Colombia, en su vida, honra, bienes, creencias, y demás derechos y libertades, y para asegurar el cumplimiento de los deberes sociales del Estado y de los particulares.

La convivencia pacífica, la protección a todas las personas en su vida, honra, bienes y demás derechos y libertades se constituyen en fundamentos del Estado Social de Derecho, en tanto que garantiza la prevalencia del interés social general como una de las características esenciales de la organización política. En este sentido, todas las actuaciones de los funcionarios del Estado deben asegurar a todos los habitantes del territorio nacional tales derechos y garantías para lo cual disponen de los recursos y los instrumentos necesarios para repeler cualquier tipo de agresión que los afecte. $^{43}$

Otro fin fundamental del Estado social de derecho es la paz, que se encuentra mencionada dentro del preámbulo de la Constitución en el que se destaca que una de las finalidades de la Carta Política es asegurar "la vida, la convivencia, el trabajo, la justicia, la igualdad, el conocimiento, la libertad y la paz"; y también se hace honor a ella en el mencionado artículo segundo, en el que se establece como uno de los fines esenciales del Estado colombiano “asegurar la convivencia pacífica y la vigencia de un orden justo. La convivencia pacífica es un fin básico del Estado y ha de ser el móvil último de las fuerzas del orden constitucional, por ello se ha reconocido que 'la paz es, además, presupuesto del proceso democrático, libre y abierto, y

${ }^{43}$ Corte Constitucional. Sentencia T-102 de 1993, Magistrado Ponente Carlos Gaviria Díaz. 
condición necesaria para el goce efectivo de los derechos fundamentales', por lo cual ocupa un lugar central en el ordenamiento constitucional ${ }^{\prime 4}$.

De otra parte, la Corte Constitucional ha expresado además que "el principio de dignidad humana y el derecho a la paz no sólo imponen el deber de prevenir la guerra sino que, en caso de un conflicto inevitable, obligan al Estado a morigerar sus efectos. En este sentido, se ha reconocido que en relación con los conflictos armados, el primer deber del Estado "es prevenir su advenimiento, para lo cual debe establecer mecanismos que permitan que los diversos conflictos sociales tengan espacios sociales e institucionales para su pacífica resolución". En este sentido, la convivencia pacífica es un fin básico del Estado, por lo cual constituye el móvil último de las fuerzas del orden constitucional, un presupuesto del proceso democrático, libre y abierto, y una condición necesaria para el goce efectivo de los derechos fundamentales" ${ }^{45}$.

\footnotetext{
${ }^{44}$ Corte Constitucional. Sentencia C - 579 de 2013, Magistrado Ponente Jorge Ignacio Pretelt Chaljub.

${ }^{45}$ Corte Constitucional. Ibíd.
} 


\section{CAPÍTULO II}

\section{FUNCIONES SOCIALES}

\section{UN MARCO TEÓRICO PARA EL ANÁLISIS}

\section{DE LAS POLÍTICAS PÚBLICAS}

Elaborar un marco teórico relativo a los principios y fundamentos del análisis funcional es el propósito de este capítulo ${ }^{46}$. El análisis funcional comprende una forma de entendimiento científico relativo a los fenómenos que estudia, es decir, constituye un modo de generalización. Las explicaciones funcionales son consideradas como una especie de análisis teleológico, por ende, de un tipo particular de revisión que no posee como objeto el estudio de las causas que producen los fenómenos, sino la observación de los fines que han sido propuestos y de las consecuencias sociales (funciones) que determinan su curso final. Exponer las bases teóricas necesarias para cumplir con el cometido anterior será el plan de este capítulo ${ }^{47}$.

\footnotetext{
${ }^{46}$ Para los no conocedores, vale la pena aclarar que este marco teórico no pertenece al ámbito de la filosofía del derecho, sino a la sociología jurídica. En consecuencia, se trata de construir un marco teórico que ilustre el análisis de una política pública, integrada por el Derecho público, esto es, por el Derecho constitucional y el administrativo, cual es la política de seguridad.

${ }^{47}$ Para el efecto, en términos generales, este capítulo estará basado en la obra de Germán Silva García. Criminología. Teoría sociológica del delito, Bogotá, ILAE, 2011, pp. 89 a 95, que por sus aportaciones teóricas originales constituye una fuente primaria. Sin embargo, se han consultado los principales autores, todos ellos fuentes primarias, que han hecho contribuciones a la materia. Ello no obsta, para que en algunas materias se hayan introducido sugerencias propias y, en otras, se hayan criticado posiciones de Silva García.
} 


\section{Conceptos de Fin y Función Social.-}

La construcción de un marco teórico relativo a las funciones sociales, que sea útil a efectos de realizar un análisis funcional de las políticas de seguridad en Colombia, debe comenzar por precisar los conceptos de fin y función y, en particular, aclarar las confusiones bastante frecuentes, tanto en el Derecho como en la sociología de estas dos categorías.

Los fines son los objetivos, propósitos, metas o finalidades perseguidas por las actuaciones, las políticas, las medidas, las normas o las instituciones. Los fines pertenecen al ámbito del deber ser, por cuanto condensan pretensiones, ideales buscados o, si se quiere, intenciones ${ }^{48}$. Están fundados en juicios de valor que se traducen en decisiones que adoptan las personas. Por tanto, los fines no son intrínsecamente ni falsos ni verdaderos, es decir, no pueden ser sometidos a procesos de verificación empírica o falsación, por lo que no pueden ser refutados en términos de las reglas de la experiencia para arribar a la conclusión de que son falsos. En cambio, puede estarse de acuerdo o en desacuerdo con ellos, lo que significa que esos fines u objetivos pueden o no ser compartidos o aceptados por otros. Y es que las decisiones no son empíricamente espurias o ciertas, solamente convocan aprobación o desaprobación. Pero aún en ese caso, pese a que no son susceptibles de verificación, podrá discutirse la estructura lógica que soporta la definición de esos fines o controvertirse los argumentos o razones en los que se apoyan. Todo lo cual, finalmente, traduce que los fines, su determinación y adopción, son una cuestión puramente subjetiva. En las condiciones descritas, es factible afirmar que los fines, al menos aquellos con alguna trascendencia, pertenecen a los campos de la filosofía y del Derecho.

\footnotetext{
${ }^{48}$ La noción básica de fin utilizada pertenece a Robert K. Merton. Teoría y estructura sociales, 3ํㅗㄹ. ed., México D.F., 1992, p. 97.
} 
Por ejemplo, la política de seguridad del presidente Juan Manuel Santos, que comprende como una de sus estrategias más importantes las negociaciones para lograr la paz con la guerrilla de las FARC-EP, ha sido discutida y rechazada por su antecesor en la presidencia, Álvaro Uribe Vélez. El expresidente alega que los crímenes cometidos por los miembros del grupo rebelde no deben quedar impunes, que no se puede negociar con delincuentes nada distinto a su sometimiento, que los delitos contra el Derecho Internacional Humanitario no pueden ser anmistiados ni indultados, etc. La meta de alcanzar la paz es una finalidad de la política de seguridad del presidente Santos, expresa un deber ser, que no puede ser sometido a un proceso de validación para determinar si es falso o verdadero. Porque perseguir la paz mediante una negociación no es algo falso ni verdadero, ni es posible adelantar una investigación empírica para demostrar que un propósito puede serlo, es una cosa con la cual se puede estar de acuerdo o en desacuerdo. Las alegaciones de Uribe Vélez, a su vez, expresan apreciaciones subjetivas y juicios de valor que exponen una disidencia, pero no demuestran empíricamente que la finalidad de la política no sea cierta. Lo que podría discutirse es la estructura lógica de la argumentación utilizada para obtener apoyo a la meta planteada.

Si hipotéticamente alguien, por ejemplo, afirmara que deben apoyarse las negociaciones de paz porque un acuerdo acarrearía el desvío de la mayor parte de los recursos gastados hoy en defensa a la atención de necesidades de salud y educación, su razonamiento carecería de una estructura lógica que lo soportara. Sucede que el presupuesto anual de defensa es de 27 billones de pesos, pero el pasivo pensional de las Fuerzas Armadas asciende a 240 billones, luego el presupuesto por años deberá destinarse a pagar los costos ya causados de la guerra. Con todo, si hipotéticamente alguien declarara que las negociaciones aparecen fundadas en el objetivo de 
contener el crecimiento del gasto de defensa, para evitar que el "hueco" financiero de la deuda pública arruine al país a mediano plazo, las mismas cifras le proveerían una base lógica a la motovación expuesta.

Las funciones sociales, de modo muy distinto, son las consecuencias sociales, los resultados, las secuelas, valga decir, las repercusiones materiales que ocasionan la ejecución o aplicación de las actuaciones, las políticas, las medidas, las normas o las instituciones. Las funciones sociales incumben al ámbito del ser, puesto que son un reflejo de los efectos que provocan en la realidad social. Aparecen fundadas en hechos sociales, esto es, en acciones sociales que son siempre las que activan los distintos canales a través de los cuales se derivan las funciones. Por ende, las funciones pueden estas sujetas a procesos mediante los cuales se constata empíricamente si son falsas o verdaderas, motivo por el que es viable falsearlas, o sea, refutarlas de conformidad con las reglas de la experiencia. Cuestiones mencionadas las cuales implican que las funciones sociales hacen parte de la dimensión objetiva de la vida social, es decir, no son subjetivas. En pocas palabras tienen que ver con hechos, no con decisiones o elecciones. Bajo los parámetros anteriores es procedente afirmar que las funciones, aquellas con cierta trascendencia, corresponden al campo de la sociología ${ }^{49}$.

La noción de función social también puede ser ilustrada por medio de un ejemplo: las ofensivas militares durante el Gobierno del presidente Álvaro Uribe Vélez, que como acciones sociales constituyen los hechos de los que se deprenden o infieren las funciones sociales, habrían tenido consecuencias materiales o cumplido funciones sociales como las de justificar el aumento de los impuestos dirigidos a sufragar la inversión en gastos de defensa, de configurar la alta

${ }^{49}$ El concepto de función social adoptado proviene de Silva García. Criminología. Teoría, cit., p. 90. 
popularidad del presidente Uribe Vélez, de transmitir entre la población un imaginario sobre la derrota militar de las FARC-EP. Varias encuestas de la época, de conocimiento común, acreditarían las funciones sociales expuestas.

Distinguir entre fines y funciones cuando se va a adelantar una descripción y un análisis que versa sobre políticas, medidas, normas o instituciones, no sólo es procedente, sino que constituye un auténtico imperativo. No es un asunto de poca importancia, se trata de diferenciar entre aquello que es planteado como un objetivo y, por otra parte, lo que sucede a la postre en la realidad social. En otras palabras, es discernir entre el "dicho" y el "hecho" o, en un plano epistemológico, son las variaciones entre el mundo del deber ser y el que corresponde al ser ${ }^{50}$. Ahora bien, esto es particularmente importante cuando se analizan políticas públicas o normas jurídicas, desde las perspectivas de la sociología política o la sociología jurídica, ya que con harta frecuencia hay una diferencia considerable entre las metas o finalidades postuladas y los resultados reales que las anteriores acarrean como efecto de la tentativa de aplicarlas o ponerlas en práctica $^{51}$.

Por ejemplo, dentro de las políticas de seguridad asumidas durante el Gobierno del presidente Andrés Pastrana Arango (1998-2002), fue creada una “zona de distensión”, cuya finalidad era generar un espacio que pudiera servir para ambientar y resguardar las negociaciones con el grupo guerrillero de las llamadas Fuerzas Armadas Revolucionarias de Colombia FARCEP. El fin planteado por el Gobierno era el de llegar a un acuerdo de paz que acabara el conflicto

${ }^{50}$ Al respecto, Silva García. Criminología. Teoría, cit., p. 94.

51 "Además, no es necesario suponer que las razones expresadas por la gente para su conducta ('actuamos por razones personales') son la misma cosa que las consecuencias de esas normas de conducta. La disposición subjetiva puede coincidir con la consecuencia objetiva, pero también puede no coincidir. Las dos varían independientemente", Merton. Teoría y estructura, cit., p. 98. 
armado interno. Sin embargo, la "zona de distensión" se convirtió en una zona de "retaguardia" segura para las FARC, que la aprovecharon para reentrenar a sus combatientes y recibir instructores extranjeros expertos en determinadas pericias militares, curar o sanar a sus heridos o enfermos, incrementar actividades ilícitas como el tráfico de drogas o el abigeato para elevar los ingresos financieros, recibir embarques de contrabando de armas y preservar sus depósitos, acumular efectivos para lanzar ataques contra objetivos fuera de la zona, hacer propaganda con impacto nacional e internacional, mantener detenidos a personas secuestradas, poner a salvo columnas o comandos guerrilleros que se retiraban luego de algún operativo fuera de la zona, etc. La función social verificada significó obtener una ventaja estratégica para incrementar el conflicto armado, lo que agravó la guerra, un fenómeno inversamente opuesto al que representaba las aspiraciones gubernamentales.

De manera adicional, tal como lo precisa Germán Silva García, es indispensable aclarar que no toda consecuencia o resultado que se produce en el mundo físico, derivado de la implementación de una actuación, una política, una medida, una norma o una institución traduce automáticamente la ocurrencia de una función social. Debe tratarse de una consecuencia social, lo que implica que debería tener un sentido significativo para otras personas, es decir, afectar a otros. Así mismo, para que pueda hablarse de la comparecencia de una función social, las acciones o los hechos o las consecuencias sociales respectivas deben representar una abstracción teórica. En verdad, las funciones sociales son abstracciones teóricas, por tanto con alguna capacidad de generalización, derivadas de los hechos materiales o acciones detectadas ${ }^{52}$.

${ }^{52}$ Silva García. Criminología. Teoría, cit., p. 90. 
Por ejemplo, frente a los asesinatos de decenas de ciudadanos civiles por parte de miembros de las Fuerzas Armadas, dentro de la problemática que ha sido conocida como los "falsos positivos", aunque las muertes de esos individuos constituyen sin duda acciones o consecuencias con implicaciones sociales, no puede aseverarse que la función social verificada ha sido la muerte de fulano o zutano, ni la pérdida de la vida de tantas personas, pues esos son hechos más no funciones sociales. Al contrario, una función social consistiría, al menos una planteada como un ejercicio hipotético, en señalar algo así como que: la Política de Seguridad Democrática del Gobierno del Presidente Álvaro Uribe Vélez (2002-2006 y 2006-2010), entre otros efectos, cumplió la función social de contribuir a exacerbar las infracciones a los Derechos Humanos, comprendidas dentro de una versión distorsionada de la eficiencia militar y el acicate de motivos francamente baladíes (varios casos sucedieron para obtener un permiso de fin de semana u otras recompensas similares). La conclusión anterior sobrepasa los meros sucesos o consecuencias, de las que representan mucho más que un mero reflejo o una figura calcada, para erigirse en una abstracción teórica, entendida como la identificación conceptual de una propiedad atribuida a un determinado objeto. Por ello se advirtió que las funciones sociales se fundan en acciones o hechos sociales, pero no son su réplica mecánica, sino una conclusión teórica que trasciende sobre ellos.

Asunto importante, en particular desde la perspectiva seguida en este trabajo, aunque desde luego contrariando otras visiones, radica en que las funciones sociales no son positivas ni negativas. Semejante clase de valoraciones son subjetivas y relativas. Las funciones, tal como ha sido señalado, se fundan en datos empíricos, no en juicios de valor. Lo que para un actor puede ser positivo, por ejemplo la esclavitud para los hacendados del algodón en el sur de los Estados 
Unidos en el siglo XIX, que así obtenían mano de obra, puede ser negativo para otros actores, como para los negros que han sido esclavizados.

Para Robert K. Merton, de un modo que envuelve variaciones importantes con la categoría antes expuesta, la función social "son las consecuencias observadas que favorecen la adaptación o ajuste de un sistema dado",53. De esa idea se comparte el elemento descriptivo que contiene, es decir, su referencia, a que se trata de "consecuencias observadas", pero no la misión que le adjudica a las funciones de favorecer "la adaptación o ajuste de un sistema dado", que sólo es entendible bajo los postulados sistémicos de la teoría sociológica estructural funcionalista que es cuestionada al final del capítulo. Al respecto, puede adelantarse que la sociedad como una realidad empírica no es un sistema, y que de acuerdo al concepto de función social adoptado ella, al menos no necesariamente, tampoco ha de contribuir a provocar adaptaciones o ajustes en la sociedad para que sea reconocida como $\operatorname{tal}^{54}$.

Vincenzo Ferrari, por su parte, señala que por "función de un elemento que opera en (o sobre) un sistema entendemos, por tanto, la tarea o el conjunto de tareas, no incompatibles entre sí, que son atribuidas con carácter primario a aquel elemento por el sujeto que actúa mediante ellos en el sistema"55. En este caso, aun cuando Ferrari rechaza la perspectiva teórica del estructural funcionalismo, de la que se aparta radicalmente, en este punto en particular se sitúa en un lugar bastante cercano a esa corriente de pensamiento. Incluso, en buena parte, aunque emplea el término tarea que difiere del utilizado por la sociología estructural funcionalista, en

\footnotetext{
${ }^{53}$ Merton. Teoría, cit., p. 126.

${ }^{54}$ Considerado que un sistema está armónicamente compuesto por varias partes, las cuales cumplen sus propias tareas, que a la vez desarrollan entre sí relaciones de cooperación para alcanzar unos objetivos comunes.

${ }^{55}$ Vincenzo Ferrari. Funciones del derecho, Madrid, Debate, 1989, p. 53.
} 
todo caso el concepto que enuncia parece enmarcarse dentro de la concepción de unidad funcional de la sociedad, noción criticada más adelante, que posee una clara raigambre estructural funcionalista.

Por lo anterior se suscribe íntegramente la tesis de Germán Silva García al criticar la postura de Ferrari cuando advierte: “Ocurre, en primer lugar, que la referencia de la función al sistema implica la adopción de las creencias del estructural funcionalismo que recién han sido cuestionadas, lo cual se reafirma de pleno en la idea de que la función es una "tarea", afirmación que tiene ese tono comentado de "utilidad" predicado respecto del sistema. En segundo lugar, sucede que el término "tarea" tiene una connotación de "misión”, lo que significaría que, en realidad, se trata de un fin y no de una función, lo cual desnaturaliza el concepto; conclusión que resulta corroborada cuando en la misma noción Ferrari insiste en que esas tareas son “atribuibles”, lo cual implica que son subjetivas, al igual que los fines. Críticas en definitiva refrendadas cuando Ferrari en otro pasaje declara que las funciones del derecho son 'entendidas como objetivos primarios asignados por los actores sociales'." ${ }^{, 56}$ Este segundo aspecto, también había sido criticado por Iván F. Pacheco, para quien la idea de "tareas” introducida por Ferrari tiene un cariz teleológico, que termina por asimilar a las funciones con fines, a lo que además agrega que es incorrecto plantear que esas tareas no pueden ser "incompatibles entre sí", puesto que el derecho, por ejemplo, puede tener funciones con direcciones muy diferentes ${ }^{57}$.

Sin embargo, ha de decirse a favor de Ferrari que pese a que de la referencia al "sistema" pareciera desprenderse que abraza la visión sistémica de la sociedad propugnada por el

\footnotetext{
${ }^{56}$ Silva García. Criminología. Teoría, cit., pp. 93 y 94.

57 Iván F. Pacheco. "El método de análisis funcional en la criminología", en Carlos Elbert (Coord.), La criminología del siglo XXI en América Latina, Buenos Aires, Rubinzal -Culzoni, 1999, p. 299.
} 
estructural funcionalismo, que también será cuestionada más adelante, lo cual conduciría a una estrecha identificación con sus postulados y principios, ello en realidad no es así, porque la interpretación de Ferrari sobre el concepto de sistema es muy distinta a la del estructural funcionalismo, según se desprende otra de sus obras ${ }^{58}$. Ese desigual entendimiento de lo que es un sistema, separa del todo a Ferrari de la filosofía social que constituye el núcleo central de la doctrina del estructural funcionalismo. La salvedad última, que al tiempo no oculta la proximidad de Ferrari a la teoría estructural funcionalista en sede del análisis funcional, en todo caso debe morigerar la crítica de Silva García, quien en su escrito no contempló las repercusiones que acarreaba el uso de un concepto diferencial de sistema por parte de Ferrari.

Norberto Bobbio, quien se interesó en forma considerable en el análisis funcional del Derecho, de manera bastante notoria recayó en el error común de confundir fines y funciones sociales. Por ello, en su discurso, al tratar del Derecho, las funciones son presupuestas o preordenadas y, así mismo, las funciones sociales son algo atribuido al Derecho, razones por las cuales puede sostener que el Derecho cumple una función promocional (en realidad un fin), basada su apreciación únicamente en normas que contienen tales propósitos u objetivos promocionales, sin referencia alguna a datos empíricos ${ }^{59}$.

Para Iván F. Pacheco la función social es “una consecuencia real con una significación social”, desprendida de unos hechos, “que en razón a su impacto y/o constancia pueden ser

\footnotetext{
${ }^{58}$ Adopta el concepto de sistema de L. von Bertalanffy (1969), según el cual el sistema es simplemente un "conjunto de elementos en interacción", Vincenzo Ferrari. Derecho y sociedad. Elementos de sociología del derecho, Bogotá, Universidad Externado de Colombia, 2006, p. 25.

${ }^{59}$ Norberto Bobbio. Contribución a la teoría del derecho, Madrid, Debate, 1990, p. 261 y 379.
} 
elevados a una categoría de abstracción teórica general". ${ }^{60}$ Versión similar a la adoptada en este trabajo, por ende, alejada de las interpretaciones sistémicas, de supuestos papeles benéficos, útiles o intencionalmente perseguidos por las funciones.

Entonces, para Vincenzo Ferrari la función generada por un evento tiene un impacto o consecuencia respecto del sistema, es decir, es funcional al sistema, lo que hasta aquí coincide con el planteo del estructural funcionalismo, sólo que la noción de sistema es sustancialmente diferente a la del estructural funcionalismo, por lo que puede concluirse, sin que ello contenga una incoherencia, que la posición de Ferrari es próxima al estructural funcionalismo y, a la par, se separa radicalmente de éste. Con mayor exactitud, Ferrari habla de "tareas" respecto del sistema, con un cierto sentido neutro, mientras que Robert K. Merton, uno de los más importantes postores del estructural funcionalismo, trata del papel de propiciar la "adaptación" o "ajuste" del sistema, que imbrica un compromiso total con el discurso estructural funcionalista. En cambio, a Germán Silva García e Iván F. Pacheco los tiene sin cuidado el "sistema”, sólo les interesa la comparecencia de consecuencias sociales de las que puede derivarse una abstracción teórica general que, como tal, supone una significación social.

De otra parte, Robert K. Merton indica que las cosas a las que se atribuyen funciones deben ser estandarizadas, por tanto reiterativas ${ }^{61}$. Empero, aunque el carácter repetido del fenómeno puede contribuir con mayor eficacia a la verificación de funciones, puesto que es más probable que puedan emerger generalizaciones teóricas, un hecho único y aislado, no reiterativo,

\footnotetext{
${ }^{60}$ Pacheco. "El método de análisis, cit., p. 303.

${ }^{61}$ Merton. Teoría, cit., p. 125.
} 
aunque posiblemente de trascendencia significativa, puede contener la potencialidad para provocar consecuencias sociales que permitan generalizaciones teóricas.

Robert K. Merton anticipó con claridad y precisión la distinción teórica entre fin y función, al igual que su importancia teórica. Con un norte análogo, Luigi Ferrajoli insistió en la trascendencia de entender las desigualdades de sentido y alcance entre los dos conceptos, lo que equivalía a comprender las diferencias entre la dimensión prescriptiva (fines) y la dimensión descriptiva (funciones) de la sociedad ${ }^{62}$. Germán Silva García aprovechó la diferenciación teórica entre fin y función expuesta por Merton y Ferrajoli para sobre ella edificar una noción alternativa de la categoría función social, ya bastante alejada del estructural funcionalismo. Iván F. Pacheco, igualmente, se apega a la distinción entre fin y función introducida por Merton. Roger Cotterrell considera clave la diferencia entre fin (purpose) y función (function), y cuestiona la tendencia a confundirlos ${ }^{63}$. Vincenzo Ferrari, a pesar de su valiosa contribución al estudio de las funciones sociales en el campo del derecho, cae en el error de confundir las dos categorías teóricas. También Norberto Bobbio mezcla los dos conceptos. En los dos últimos casos el fallo radica en no advertir la relevancia de poder compararlos y contrastarlos.

Pese a que las diferencias entre los conceptos de fin y función social son diáfanas, tal como ha sido acreditado en la anterior exposición, en el terreno específico del Derecho es usual su confusión. El ordenamiento jurídico colombiano hace alusión a supuestas funciones, que predica de determinadas instituciones, cuando en verdad está refiriéndose a fines que busca e intenta materializar el Estado, muchas veces sin éxito real. Sea que lo anterior acaezca en virtud

62 Luigi Ferrajoli. "El derecho penal mínimo", en Prevención y teoría de la pena, Santiago de Chile, Jurídica Cono Sur, 1995, pp. 26

${ }^{63}$ Roger Cotterrell. Introducción a la sociología del derecho, Barcelona, Ariel, 1991, p. 72. 
al desconocimiento por parte del legislador del alcance del concepto de función social, que se repite pertenece a la sociología y a la antropología social, o que con un afán "voluntarista" haya querido idealizar la eficacia del Derecho, presumiendo que una institución jurídica por la simple circunstancia de haber sido incorporada al ordenamiento normativo ya alcanza eficacia material, lo cierto es que reviste de una importancia considerable disponer de los elementos teóricos, esto es, conceptuales, para diferenciar entre lo que el legislador ha planteado como su aspiración, y aquello que sobreviene en el mundo real de la sociedad.

Precisamente, uno de los aspectos de mayor relevancia de las contribuciones de la sociología jurídica radica en los estudios sobre la eficacia del Derecho e instituciones estatales, como por ejemplo, la administración de justicia. De manera genérica la sociología jurídica se dedica a estudiar las relaciones entre Derecho y sociedad ${ }^{64}$. También se ha dicho que la sociología jurídica es la especialidad de la sociología que estudia las estructuras sociales (instituciones) relativas al control social jurídico en su relación con las prácticas sociales (interacciones) que acaecen en la sociedad ${ }^{65}$. Y las categorías teóricas de fin y función social son fundamentales para poder acometer esa exploración teórica, ya que permiten advertir las diferencias entre el Derecho (la teoría) y la vida social (la praxis) o, lo que puede ser más preciso, entre estructuras sociales como el Derecho (la teoría) y las interacciones sociales (la práctica). Exactamente, se ha advertido que una cuestión esencial sobre la importancia de los conceptos de fin y función es que, en el análisis crítico del Derecho, permite discernir entre teoría y práctica, lo que no es un asunto inane o inocuo. Finalmente, la cuestión que envuelve el contraste entre teoría y práctica de las figuras jurídicas es la eficacia del Derecho, que como

\footnotetext{
${ }^{64}$ Renato Treves. Introducción a la sociología del derecho, Madrid, Taurus, 1985, p. 21.

${ }^{65}$ Silva García. Criminología. Teoría, cit., p. 24.
} 
señalamos al comienzo es una de las facetas más importante del objeto de estudio de la sociología jurídica. Y también, sin duda, hace parte de la problemática relativa a la teoría del derecho.

Entre los ejemplos clásicos que son citados de normas jurídicas que incurren en el yerro de confundir los conceptos de fin y función, citadas a efectos de ilustrar la explicación, se encuentran los mandatos sobre la "función" social de la propiedad y las "funciones" de las sanciones penales.

La Constitución Política de Colombia en su artículo 58 establece que "la propiedad es una función social que implica obligaciones". La norma ni siquiera señala que la propiedad tiene o cumple una función social, sino que directamente es una función social, lo que agrava el desacierto. Empero, lo que en verdad plantea la norma apunta a que la propiedad tiene un fin social, lo cual expresa un deber ser, un propósito político propio del Estado social de derecho. Puede que ese fin u objetivo, por medio de la práctica del Derecho, se haya transformado en una realidad, en cuyo caso sí cumpliría una función social. No obstante, para arribar a la última conclusión resultaría indispensable reunir datos empíricos que le dieran soporte probatorio. Si se tomara la aplicación de Ley 200 de 1936, que supuestamente materializaba la reforma constitucional del mismo año en que había sido introducida la regla sobre la finalidad social de la propiedad, tendría que decirse que dicha norma no sólo no cumplió una función social, sino que al contrario, en razón a su manipulación y a otras variables, sirvió para incrementar la acumulación de la propiedad y consolidar el modelo económico de la hacienda, dedicada a la ganadería extensiva. Desde la época de La Violencia, acaecida entre 1946 y 1964, después sobre 
todo a partir de la década de los años 80 , también el siglo XX, en razón del narcotráfico y del paramilitarismo, la propiedad lejos de materializar una función social, que limitara el Derecho de dominio y lograra efectos como la democratización de la tenencia de la tierra y un desarrollo agrario equilibrado y justo, tuvo efectos en la legalización de una creciente acumulación de la tierra en pocas manos y de los despojos violentos e ilegítimos.

El Código Penal colombiano establece en su artículo 12 que la pena tiene "funciones" sociales de resocialización, prevención, retribución y protección. Sin embargo, sin duda se trata de fines, entendidos como metas que representan una mera aspiración. Como ha sido ampliamente demostrado por diversas investigaciones empíricas la pena, en particular la de prisión, cumple en Colombia funciones sociales que distan de manera abismal de esas pretensiones. Situación que, además, se repite de manera crónica en otros países. En el mismo artículo 12 citado, en cambio, el legislador fue bastante más acertado al referirse a las medidas de seguridad cuando señaló que "persiguen fines de curación, tutela y rehabilitación”. Ya aquí el legislador hace referencia específica a "fines", pese a que el título del artículo alude a "funciones", lo que evidencia la confusión conceptual y, en forma adicional, utiliza el verbo perseguir, lo que pone de presente con contundencia que se trata de finalidades u objetivos que son buscados.

En cambio, la prisión con el concurso directo de la finalidad de la resocialización, en la medida que introduce un sistema de recompensas y castigos para regular el comportamieno de los reclusos a través de la institución del "sistema progresivo penitenciario", por ejemplo, realiza la función social de procurar el mantenimiento de la disciplina de los reos, evitando los motínes, 
el desórden o la desobediencia. La prisión, en general, contribuye a la reproducción de la criminalidad, cuando quiera que la cárcel se convierte en la "universidad del delito". Es decir la prisión cumple la función social de socializar al prisionero en nuevas técnicas y estrategias para la comisión de delitos, suministrándole los conocimientos necesarios mediante el intercambio de saberes con otros reclusos. La prisión, igualmente, ejecuta la función social de procrear subculturas carcelarias, con valores y normas sociales de obligatorio acatamiento, que se imponen por encima de los reglamentos penitenciarios.

El error relativo a las supuestas "funciones" de la pena es común y tiene antecedentes entre autores clásicos. Edwin Sutherland, por ejemplo, refería las funciones a propósitos de las sanciones penales como la expiación o la disuasión ${ }^{66}$. Empero, como se ha dicho y conviene refirmarlo: "la expresión función social se refiere a consecuencias objetivas observables, y no a disposiciones subjetivas (propósitos, motivos, finalidades). Y el no distinguir entre las consecuencias sociológicas objetivas y las disposiciones subjetivas lleva inevitablemente a confusión en el análisis funcional”, ${ }^{\text {. }}$.

2.- Clases de Funciones Sociales.-

La clasificación de los distintos tipos de funciones sociales que pueden verificarse enriquece las herramientas conceptuales para adentrarse en el método de análisis funcional.

${ }_{66}^{66}$ Edwin H. Sutherland. Principles of Criminology, $3^{\mathrm{a}}$ ed., Philadelphia, J.B. Lippincott, 1939, p. 349.
${ }^{67}$ Merton. Teoría, cit., p. 97. 
Robert K. Merton hizo referencia a las funciones manifiestas y latentes. Las primeras corresponden a aquellas que coinciden o se identifican con los fines postulados. Es decir, la actuación, medida, norma, política o institución tiene un determinado fin u objetivo el cual, previa constatación empírica, aparece realizado o alcanzado como consecuencia de la operación o despliegue en la praxis de la actuación, política, medida, norma o institución respectiva. De modo del todo diverso, las funciones sociales latentes están referidas a aquellas consecuencias sociales que difieren de los fines planteados o perseguidos. En otras palabras, la actuación, medida, norma, política o institución tiene un determinado fin u objetivo que, de acuerdo con la información empírica recaudada, no ha tenido ejecución alguna como resultado de la puesta en práctica de la actuación, política, medida, norma o institución correspondiente ${ }^{68}$. Esto es harto frecuente en materia de políticas y de normas jurídicas.

Germán Silva García, acogió la clasificación de Merton, que sumaría a las funciones sociales simbólicas postuladas por Joseph R. Gusfield que se verán enseguida, pero en concordancia con lo antes expuesto rechazó las alusiones de Merton al papel de tales tipos de función respecto de la adaptación o ajuste al sistema ${ }^{69}$. En efecto, Merton, a tono con su vocación estructural funcionalista, consideraba que las funciones sociales manifiestas eran consecuencias objetivas que contribuían al ajuste o adaptación del sistema y que eran buscadas por los participantes, mientras que las latentes no serían consecuencias buscadas ni reconocidas y, por ende en sana lógica, no podían contribuir a la adaptación o ajuste del sistema, sino que serían inocuas o contrarias a esos procesos adaptativos. Con todo, asunto sobre el que se retorna al final del capítulo, la filosofía social estructural funcionalista no es compartida, ni la adaptación

\footnotetext{
${ }^{68}$ Merton. Ibíd., p. 126.

${ }^{69}$ Silva García. Criminología. Teoría, cit., p. 91.
} 
es el foco de atención. Incluso una política o una norma, por ejemplo, pueden cumplir una función social manifiesta en tanto y en cuanto coinciden con la finalidad perseguida, sin que ninguna de las dos tenga nada que ver con la adaptación o el ajuste sistémicos.

Interesan de sobre manera las categorías de funciones manifiestas y latentes, puesto que son los conceptos que permiten desarrollar un juego de paradojas, al marcar los grandes contrastes entre aquello que se pretende y lo que ocurre en realidad. Como lo declara Robert K. Merton "la distinción entre funciones manifiestas y latentes fue ideada para evitar la inadvertida confusión, que se encuentra con mucha frecuencia en la literatura sociológica, entre motivaciones conscientes para la conducta social y sus consecuencias objetivas. ${ }^{, 70}$ Dos cosas que, por su naturaleza y alcance, son muy dispares. En la misma dirección, no interesa si la función latente, además de no anticipada o imprevista, pueda resultar o no indeseada. Lo relevante es que sea distinta a la motivación o finalidad planteada.

El ejemplo, ya expuesto, sobre las negociaciones de paz y la creación de la zona de distensión, durante el Gobierno del presidente Andrés Pastrana Arango, que proveyó una zona de retaguardia segura a las FARC-EP y desempeñó la función social de agudizar la guerra es, sin duda, un caso de función social latente.

Debe tenerse en cuenta que un mismo hecho puede provocar, en forma simultánea, funciones sociales manifiestas y latentes. Las negociaciones de paz con el Ejército Popular de Liberación EPL, en el transcurso del Gobierno del presidente Virgilio Barco, conllevo la función social manifiesta de producir un acuerdo de paz, que condujo al desarme y la desmovilización de

${ }^{70}$ Merton. Teoría, cit., p. 136. 
los guerrilleros del EPL. Pero al tiempo, consumó con funciones sociales latentes. Entre ellas, engendró la función social latente de facilitar el dominio de las FARC-EP sobre el importante territorio de Urabá, por cuanto los guerrilleros desmovilizados del EPL fueron desplazados y sustituidos por guerrilleros de las FARC-EP, que además realizaron múltiples ataques contra campesinos simpatizantes del EPL y militantes del nuevo grupo político emergente Esperanza Paz y Libertad, todo ello dado que las Fuerzas Armadas no tuvieron la capacidad para asegurar el territorio que cedía el EPL. El anterior, desde luego, no era el fin perseguido por el Estado en su negociación o acuerdo con el EPL.

En el evento de las funciones sociales simbólicas no comparece una consecuencia social que tenga una traducción material, es decir, no hay un hecho social cierto y verificable a partir del cual se deriva la ocurrencia de la función social. Lo que concurre es un sensación o apariencia de haberse verificado el hecho o consecuencia, y sobre ellas de edifica la función social. Si se quiere, para ganar mayor claridad, las funciones sociales simbólicas se distinguirían de las instrumentales, en donde el hecho sí ha sucedido ${ }^{71}$.

A modo de ejemplo, cabe recordar que durante el Gobierno del presidente Virgilio Barco (1986-1990), en momentos en los que se enfrentaba una guerra narcoterrorista que parecía desbordada, sin que el Estado mostrara mayores posibilidades de contrarrestarla, son expedidos varios decretos de Estado de Sitio con medidas bastante severas. Uno de ello fue el Decreto 2490 de 1988, expedido con fundamento en el Decreto 1038 de 1984 que había implantado el Estado de Sitio, en virtud del cual fue erigida la pena de cadena perpetua para el delito de homicidio con

${ }^{71}$ Joseph R. Gusfield. Contested Meanings: the Construction of Alcohol Problems, Madison, Wisconsin University, 1996, pp. 171 y ss. 
fines terroristas cometido por miembros de grupos armados ilegales. La función social producida, de tipo simbólica, fue la de generar la sensación de que el Gobierno obraba con drasticidad y eficacia para garantizar la seguridad y neutralizar a los narcoterroristas, aun cuando dicha función no se fundaba en ningún evento fáctico, pues la norma nunca llego si quiera a intentar aplicarse, no sólo por su corta vida, sino sobre todo porque el problema era que las autoridades ni siquiera aprendían a los autores de tales homicidios, luego mucho menos estaban en condiciones de procesarlos e imponerles la prisión perpetua.

También, por ejemplo, en época reciente en la que la guerrilla de las FARC-EP ejercía una capacidad de interferencia importante en arterias de la red de carreteras, el Gobierno hizo presencia militar y procuró neutralizar las intervenciones de los insurrectos. Empero, en muchas vías que, en realidad, no estaban afectadas por problemas de seguridad, las Fuerzas Armadas hacían una presencia mínima y, a la par, colocaban figuras en cartón de tamaño natural y a color con la imagen de un policía con una señal de alto. En ese caso, no había acaecido hecho alguno que significara un incremento del patrullaje por parte de las fuerzas de seguridad del Estado, es decir, el suceso o evento no se había verificado, pero no obstante cumplía la función social de elevar el sentimiento de seguridad, a partir de la simple apariencia de una mayor presencia de efectivos policiales en esas vías.

Emiro Sandoval Huertas hablaba de funciones declaradas y no declaradas, para referirse a las penas. El desarrollo de su trabajo es interesante. Sin embargo, los conceptos que utiliza como fundamento son erróneos y confusos. Las “funciones declaradas” están referidas a aquellos objetivos que son anunciados o planteados, mientras que las "funciones no declaradas" o no 
reconocidas son "aquellas situaciones que resultan directa o indirectamente" de la aplicación de la institución ${ }^{72}$. Las llamadas "funciones" declaradas son confundidas con los fines. Las denominadas funciones no declaradas, que sí son funciones, equivalen a las funciones latentes. Además, como lo explica Germán Silva García, no sólo no todos los fines son declarados sino que, incluso, esos fines no declarados podrían dar lugar tanto a funciones sociales manifiestas como latentes. Podría haber fines que no se enunciaron, otros que se ocultaron, reservaron o falsearon de manera deliberada, aunque en todos estos casos pueden llegar a ser deducidos ${ }^{73}$.

Con relación a los fines comparecen numerosas variables que, aun cuando no afectan el marco teórico que ha sido expuesto, deben ser tenidas en cuenta. Determinados dispositivos, por ejemplo, un estatuto jurídico o una política pública pueden tener simultáneamente varios fines con orientaciones diferentes. Muchas veces en los procesos de creación de las normas legales o de construcción de las políticas públicas, dado que negocian actores con variadas ideologías e intereses, se logra un acuerdo convencional mediante un tipo de fórmula abierta a distintas interpretaciones, donde cada partido interviniente cree que la formula transaccional concreta y refleja su punto de vista. También esos mismos dispositivos pueden haber sido elaborados en una época pasada con unos determinados fines y, años después, dentro de un contexto social transformado, les son asignados finalidades muy disímiles. Si esos últimos objetivos son los que impulsan las nuevas aplicaciones o implementaciones deberán ser los tenidos en cuenta para el análisis funcional. Los fines no son inmutables y el análisis funcional puede adaptarse a esos cambios e, igual, realizar sus cometidos. Ya se señaló que los fines puede ser desconocidos, pero es posible indagar cuáles serían esas metas observando los medios que se despliegan, pues los

72 Emiro Sandoval Huertas. Penología. Parte especial, Bogotá, Universidad Externado de Colombia, 1984, pp. 249 y 251.

${ }^{73}$ Silva García. Criminología. Teoría, cit., p. 94. 
mismos deben ser idóneos o racionales para alcanzar unos ciertos resultados, esto es, la incógnita que se pretende identificar.

Puede haber casos en los que las finalidades auténticas no son declaradas, para en reemplazo de ellas presentar otras falsificadas. Desde luego, aquí el problema comparece para el investigador que debe contar con información que le permita descubrir la estratagema. En ese caso los conceptos de fines declarados y no declarados serán útiles. El examen de la clase de funciones que se realizan se surtirá respecto de los fines no declarados.

3.- La Metodología de Análisis Funcional y otras Categorías-

Al comienzo del capítulo se hizo alusión al análisis funcional. La referencia es importante, puesto que debe distinguirse entre el análisis funcional como un método dirigido a la investigación, estudio y examen crítico de los fenómenos sociales y, por otra parte, la teoría sociológica o la filosofía social funcionalista. Como de manera parcial se ha visto en razón a la orientación y trayectoria de varios de los autores que han sido citados, y como volverá a insistirse ahora, en buen parte los principales conceptos teóricos utilizados tienen su origen en la teoría sociológica estructural funcionalista. A dicha tradición teórica pertenece Robert K. Merton, cuyas contribuciones teóricas fueron fundamento principal del marco teórico que ha sido construido en este capítulo. Esto significa que el análisis funcional, en cuanto método de trabajo, tiene que ver estrechamente con aspectos de la teoría sociológica estructural funcionalista, que toma como una de sus fuentes principales, pero definitivamente son dos cosas distintas, tal como 
se verá enseguida. Y, es más, este trabajo no puede considerarse ni de manera remota un desarrollo de la teoría sociológica estructural funcionalista, dado que no comparte sus premisas doctrinales, sino que corresponde a una tentativa de edificar las bases indispensables para aplicar el método de análisis funcional.

Precisamente, Vincenzo Ferrari distinguió con claridad diáfana entre la teoría estructural funcionalista y el método de análisis funcional. Ferrari apoyado en el trabajo del sociólogo estadunidense Kingsley Davis, el primero en sostener que podía diferenciarse entre la teoría y el método relacionados con el funcionalismo, advirtió que: "respecto del funcionalismo se produce una actitud dubitativa. Por un lado no se quiere adherir a una concepción que a menudo parece decantarse en una justificación de lo existente; por otro, no se quiere renunciar a una aproximación metodológica bastante fértil, la única que quizá permite a las ciencias sociales intentar 'explicaciones' sin caer en apriorismos cognoscitivos. ${ }^{, 74}$ Mientras que en forma paralela Roger Cotterrell sostuvo que, pese a los defectos imputados a la escuela estructural funcionalista, “el método funcionalista es un instrumento básico y probablemente indispensable para la interpretación sociológica del Derecho, de ahí su utilización en los estudios inspirados en los más variados ideales políticos, incluyendo algunas formas de la teoría marxista., ${ }^{, 5}$

Aquí cabe recordar que la teoría estructural funcionalista, que para muchos no es una teoría sociológica, sino una especie de filosofía social, supone que la sociedad constituye un sistema integrado por subsistemas sociales, los cuales desarrollan relaciones armónicas de cooperación, que generan estabilidad social, lo que a priori implica una visión idílica de la

\footnotetext{
${ }^{74}$ Ferrari. Funciones, cit., p. 34.

${ }^{75}$ Cotterrell. Introducción, cit., p. 88.
} 
sociedad como un ente caracterizado por el equilibrio y la armonía, que ensalza el statu quo ${ }^{76}$. Es la misma concepción funcional relacionada con la biología, que supone que las funciones tienen que ver con "procesos vitales u orgánicos y que contribuyen al sostenimiento del organismo". 77 Pero creer que los dispositivos cumplen funciones sociales que favorecen la adaptación o ajuste del sistema social, tal como lo planteaba Robert K. Merton, no tiene ningún fundamento empírico que permita probarlo.

En lo que concierne a la última cuestión, George Ritzer es contundente en su crítica. Ritzer apuntaba: "De acuerdo con Merton, las funciones se definían como 'las consecuencias observadas que favorecen la adaptación o ajuste de un sistema dado'. No obstante, hay un claro sesgo ideológico cuando uno se centra exclusivamente en la adaptación o el ajuste, porque invariablemente se trata de consecuencias positivas. Es importante señalar que un hecho social puede tener consecuencias negativas para otro hecho social.." ${ }^{, 78}$ Entonces no sólo la referencia de todo el análisis funcional a un sistema social, que no tiene existencia real, es bastante discutible, sino atribuirle a las funciones, para que sean tales, la misión positiva de aportar a la adaptación. En efecto, de modo distinto, tendríamos funciones sociales verificadas siempre que concurra una consecuencia material con una significación social que permita una generalización teórica, aunque se trate de funciones que nada tengan que ver con el ajuste o la adaptación a la vida social.

\footnotetext{
${ }^{76}$ Tal es la visión de Talcott Parsons. El sistema social, $2^{\underline{a}}$ ed., Madrid, Alianza Universidad, 1984, pp. 238 y ss.

${ }^{77}$ Ludwig von Bertalanffy. Modern Theories of Development, New York, Oxford University, 1933, pág. 9 y SS.

${ }^{78}$ George Ritzer. Teoría sociológica contemporánea, 3ª ed., Madrid, McGraw Hill, 1993, p. 129.
} 
Entonces, en abierto contraste con la doctrina estructural funcionalista, la sociedad es entendida como una acumulación de grupos contrarios y dinámicos en equilibrio oscilante, que se forman, disuelven y reconstituyen, con el propósito de realizar sus intereses o imponer sus ideologías, de los que se derivan relaciones de cooperación y/o conflicto, lo que produce cierto orden social y, también, algún desorden ${ }^{79}$. De allí que autores citados, como Vincenzo Ferrari, Norberto Bobbio, Iván F. Pacheco y Germán Silva García opten por utilizar el método de análisis funcional, a la par que se alejan del estructural funcionalismo como doctrina de la filosofía social (aun cuando con diferencias de grado), lo que constituye la línea adoptada en este trabajo. Finalmente, el estudio de las funciones sociales no tiene una razón por la cual deba estar encaminado a examinar su papel en la supuesta integración de la sociedad. Las funciones sociales pueden tener efectos sobre la producción de órdenes o de desórdenes, en la gestación de relaciones de cooperación o de conflicto, en la realización de los objetivos que han motivado las acciones sociales y, así mismo, en la configuración o disolución de grupos sociales. Simplemente se trata de identificar cuáles son las funciones, ellas de muy variadas clases, producidas respecto de la sociedad.

De allí que, por una parte, entre las perspectivas sociológicas que hacen énfasis en la integración y, por otra, las que ponen el acento en la conflictividad social, se prefiera la segunda opción, a la par que nos alejamos de la primera alternativa, con la cual se identifica el estructural funcionalismo. Visiones equilibradas sobre el conflicto y la cooperación, pese a sus tendencias conflictualistas, como las expuestas por Germán Silva García y Vincenzo Ferrari, que no ven la problemática de la cooperación y el conflicto como cuestiones bipolares, sino como aspectos

${ }^{79}$ Silva García. Criminología. Teoría, cit., p. 196. 
dialécticos que se entrelazan para influirse mutuamente, parecería tener mucho más sentido y, sobre todo, correspondencia con la realidad social ${ }^{80}$.

Es claro que Robert K. Merton tendió las bases fundamentales, en especial en el nivel conceptual, sobre los que se ha edificado el método de análisis funcional. En sentido, George Ritzer ilustra el proceso: "Mientras Talcott Parsons es el teórico estructural funcional más notable, fue su discipulo Robert Merton quien desarrolló algunos de los enuncidos más importantes del funcionalismo estructural en sociología. Merton criticó algunos de los aspectos extremos e indefendibles del funcionalismo estructural. Pero al mismo tiempo desarrollo una perspectiva conceptual que contribuyó a perpetuar la validez del funcionalismo estructural. ${ }^{\wedge 1}$ En este texto, de modo general, se han aprovechado los desarrollos conceptuales de Merton en el campo del método de análisis funcional, como igualmente se tomaron sus críticas a las facetas más debatibles del discurso estructural funcionalista relacionadas con el análisis funcional, pero también han sido descartados los elementos con los que Merton todavía vinculaba el análisis funcional con los ejes de la teoría estructural funcionalista. Sobre los pilares que acaban de exponerse relativos al legado de Merton, enseguida, son planteados cuatro puntos aclaratorios sobre el análisis funcional.

No sobra señalar en primera instancia que, como método, el análisis funcional es una herramienta útil para examinar fenómenos sociales como las políticas de seguridad. Lo anterior, puesto que marca un sendero por el cual deben marchar las indagaciones. Es decir, en aplicación

\footnotetext{
${ }^{80}$ Al respecto, Silva García. Criminología. Teoría, cit., pp. 193 a 209. Vincenzo Ferrari. Acción jurídica y sistema normativo. Introducción a la sociología del derecho, Madrid, Universidad Carlos III de Madrid y Dykinson, 2000, pp. 137 a 146.

${ }^{81}$ Ritzer. Teoría sociológica, cit., p. 128.
} 
del método de análisis funcional se deben establecer cuáles son los fines de las políticas, si ellos son declarados o no declarados y, a continuación, identificar cuáles son las funciones sociales que se han verificado, como también si ellas son manifiestas, latentes o simbólicas. La comparación entre fines y funciones será provechosa para avanzar en la interpretación de la problemática que constituya el objeto específico de estudio.

En segunda instancia, la explicación previa permite comprender la no utilización del concepto de disfunción social, introducido por la escuela sociológica del estructural funcionalismo, intensamente conectado a sus planteamientos de filosofía social. Las disfunciones serían para Robert K. Merton "las consecuencias observadas que aminoran la adaptación o ajuste al sistema" ${ }^{\text {} 22}$. La noción es un reflejo, obviamente con un significado inverso, del concepto de función social de Merton, por lo que igualmente le caben todas las críticas que en su momento se plantearon. Pero, además, aunque no se haga explícito, es evidente que la categoría de disfunción tiene un alcance de consecuencia "negativa", diferente al de las funciones que serían "positivas", cuando ello depende "del cristal con el que se miren" esas consecuencias. Lo que para unos será funcional, para otros vendría a ser disfuncional. Por ende, es una cuestión relativa y subjetiva. Son juicios de valor que no hacen parte del ejercicio de la sociología, lo que no significa que sean inválidos, pueden ser legítimos e incluso convenientes, pero debe entenderse que cuando se hacen esa clase valoraciones el analista se adentra en el terreno de la filosofía social o política. De otra parte, para Merton las funciones sociales latentes, que eran consecuencias inesperadas o no previstas, en todo caso también contribuían a la adaptación o ajuste del sistema social, pues si no tenían ese efecto serían "no funciones" y si el impacto resultante era contrario a la adaptación o ajuste del sistema se trataría de disfunciones.

${ }^{82}$ Merton. Teoría, cit., p. 126. 
En este escrito no habría "no funciones", pues ellas no tienen que buscar la adaptación o ajuste al sistema para que sean tales, luego siempre que existan consecuencia de las cuales pueda hacerse una abstracción teórica con una significación social, esto es, para la sociedad, habrá una función social. Las funciones sociales latentes lo serán en razón de su contrariedad o diferencia respecto de los fines, sintener en cuenta si juegan o no a favor de la integración social. En las condiciones anteriores no habrá de hacerse uso de la categoría de disfunción, y si son introducidos juicios de legitimidad sobre las funciones no se hará una falsificación de la sociología para presentarlos como partes de ella. Es más, como las funciones son consecuencias sociales, en tanto tales son neutras, ni positivas ni negativas, por lo cual con independencia de nuestro gusto, parecer o conveniencia, siempre serán funciones a secas.

En tercera instancia, resulta necesario aclarar que el concepto de "unidad funcional de la sociedad" no es acogido. El mismo es utilizado para referirse a una institución, hecho o acción social particular que tiene un efecto favorable a la totalidad de la sociedad o a otros de sus aspectos. En esos términos, de manera análoga, se suele decir que una determinada cosa "es funcional" a otra o, por ejemplo, que una cierta práctica social, como el eficaz cumplimiento de los mandatos religiosos, resulta "funcional" a la totalidad del sistema social, porque coadyuva a la preservación de la moralidad pública. La noción comentada en forma implícita le atribuye un significado positivo a la unidad funcional lo cual, por una parte, es bastante relativo porque depende de las distintas posiciones, intereses e ideologías de los actores, para los cuales una cosa según "como le vaya" podrá ser "funcional" o no y, por otra parte, la valoración envuelta es subjetiva al envolver un juicio de valor, y la sociología debe trabajar con categorías objetivas. 
Igualmente, el concepto de unidad funcional tiende a ver a la sociedad como un sistema, donde la actividad de uno de sus subsistemas despliega consecuencias benéficas sobre otros subsistemas, lo que contribuye a generar estabilidad y orden. Esta visión sistémica de la sociedad no es compartida. Es una de las creencias propias de la sociología estructural funcionalista. No obstante, la sociedad no puede ser vista en el ámbito sociológico como un sistema, sino apenas en un plano del deber ser. Un fenómeno social puede tener consecuencias sobre otros componentes de la sociedad, en algunas situaciones, y en ese sentido, y sólo en dicho sentido, decirse que algo resultó funcional para otro de tales componentes, pero no siempre es así, y en ningún caso ello puede ser percibido como algo favorable o positivo.

El mismo Robert K. Merton fue bastante crítico de la noción de unidad funcional: "No hay que ir muy lejos para demostrar que el supuesto de la unidad funcional completa de la sociedad humana es con frecuencia contrario a la realidad". También sostuvo que debía señalarse para qué o quiénes resultaba funcional, y que no podía hablarse de la funcionalidad como algo universal o necesario ${ }^{83}$. Por lo demás ya fue expuesta la crítica a las ideas de estabilidad, cooperación y orden del estructural funcionalismo.

En cuarta instancia la acepción "exigencias funcionales", que sería la contrapartida del papel funcional o unidad funcional, ya que involucra las necesidades o requisitos previos de los cuales debe disponer el sistema para que el evento pueda ser "funcional" a sus propósitos, no es compartida ni utilizada ${ }^{84}$. La razón es que utiliza los mismos supuestos del concepto de unidad funcional, que ya fueron cuestionados. La noción de exigencias funcionales supone que hay unas

\footnotetext{
${ }^{83}$ Merton Teoría, cit., pp. 100 a 110.

${ }^{84}$ Merton. Ibíd., p. 127.
} 
condiciones que son indispensables para la sobrevivencia del sistema, lo que no tiene asidero empírico. El propio Merton, dudaba de la posibilidad de constatar empíricamente la existencia de las mencionadas exigencias funcionales y advertía: "Incrustada en todo análisis funcional hay alguna concepción, tácita o expresa, de las exigencias funcionales del sistema estudiado. Como se advierte en otro lugar, éste sigue siendo uno de los más nebulosos y empíricamente más discutibles conceptos de la teoría funcional. Utilizado por los sociólogos, el concepto de exigencia funcional tiende a ser tautológico". 85 En consecuencia, las categorías teóricas utilizadas no han sido deliberadamente preparadas con relación a algún parámetro de supervivencia o ajuste.

Sobre la última cuestión, también George Ritzer apuntaba para ganar mayor claridad teórica: "En tercer lugar el postulado de la indispensabilidad, que sostiene que todos los aspectos estandarizados de la sociedad no sólo cumplen funciones positivas, sino que representan también partes indispensables para el funcionamiento del todo. Este postulado conduce a la idea de que todas las funciones y estructuras son funcionalmente indispensables para la sociedad. Ninguna otra estructura o función podría funcionar mejor que la que de hecho se encuentra en cada sociedad. La crítica de Merton, de acuerdo con Parsons, era que al menos debíamos admitir que existían diversas alternativas funcionales y estructurales que podían adecuarse a la sociedad." 86

Vicenzo Ferrari acompaña a otros autores en su tentativa de establecer, para el caso singular del Derecho, una funciones sociales universales, que conviene revisar con el propósito de definir algunas pautas del trabajo con el método de análisis funcional. Entre tales funciones

\footnotetext{
${ }^{85}$ Merton. Ibíd., p. 127.

${ }^{86}$ Ritzer. Teoría sociológica, cit., p. 129.
} 
sociales universales se encuentran: 1. La orientación social; 2. El tratamiento de conflictos; C. La legitimación del poder. Sobre esta materia es necesario hacer varias declaraciones ${ }^{87}$. La primera de ellas es que, en todo caso, la verificación de las funciones sociales debe ser acreditada empíricamente ${ }^{88}$. Por tanto no es de recibo, la categoría de funciones sociales universales, puesto que la cualidad de universal quiere indicar que son constantes en todo momento o lugar, lo que no es cierto ni comprobable. De manera adicional, cuando se trata de generalizaciones mayores como las que propone Ferrari, es decir, de unas funciones sociales bastante globales, lo más probable es que ellas se realicen durante ciertos periodos y/o con relación a determinados dispositivos, como ciertas instituciones, pero no respecto de todas, como tampoco estarían en condiciones de operar frente a todos los grupos sociales. Los problemas indicados obedecen, muy posiblemente, a que Ferrari mezcla las nociones de fin y función social. La situación, tal vez, sería distinta si se pretendiera hablar de fines universales del Derecho.

Al tiempo, la idea de funciones universales está conectada a la de funciones positivas, noción ya bastante cuestionada. En ese sentido, agrega George Ritzer, comentando las críticas de Rober K. Merton a esa premisa teórica: "El funcionalismo universal constituye el segundo postulado, que presupone que todas las formas y estructuras sociales y culturales estandarizadas cumplen funciones positivas. Merton señalaba que este postulado contradecía lo que ocurría en el mundo real. Era evidente que no toda estructura, costumbre, idea, creencia, etcétera, cumplía funciones positivas." ${ }^{, 89}$

\footnotetext{
${ }^{87}$ Ferrari. Funciones, cit., p. 111.

${ }^{88}$ Lo que puede hacerse dirctamente emprendiendo una investigación empírica o recurriendo a fuentes secundarias que, a su vez, incorporen datos empíricos.

${ }^{89}$ Ritzer. Teoría sociológica, cit, p. 28.
} 
Sin embargo, ninguna de las advertencias y limitaciones anteriores obsta para que las funciones sociales generales, con un alto grado de recurrencia, puedan ser utilizadas como modelos ideales, para que mediante la aplicación de un método comparativo puedan ilustrar el análisis de nuevas situaciones sociales.

Cabe recordar que los modelos o tipos ideales, que dieron lugar a la sociología comprensiva, que pretende entender los fenómenos sociales que estudia, en vez de buscar sus causas, supone la construcción de esos modelos ideales a partir de la investigación empírica ${ }^{90}$. Estos modelos son ideales, en la medida en que reúnen las características que hipotéticamente representan mejor sus rasgos, en una forma "pura" que pocas veces se reproduce en la vida práctica, puesto que en la realidad las tipologías aparecen representados de manera impura, o sea, mezclando elementos de distintos modelos. Luego los modelos son empleados para orientar nuevas investigaciones, ya que guían al investigador en torno a lo que debe buscar y a las preguntas que se debe plantear. Para el efecto, el investigador compara los datos del modelo ideal con los que provienen de las observaciones de la realidad social. Todo lo cual puede empleado en el análisis de las funciones sociales, aparezcan ellas referidas al Derecho, como en el caso de Ferrari, o a las políticas públicas, como en el caso de este escrito.

De la exposición anterior, considerando sus distintos aspectos, debería haber quedado claro que el modelo de análisis funcional constituye una alternativa teórica y, sobre todo, metodológica, que se opone a la escuela del estructural/funcionalismo. El modelo de análisis funcional al que ha sido dedicado todo el apartado tercero de este capítulo constituye, ante todo,

90 Se trata de contribuciones, como la referida a la sociología comprensiva y a los modelos o tipos ideales, desarrolladas, sobre todo, por Max Weber. Economía y sociedad, $2^{\mathrm{a}}$ ed., México D.F., Fondo de Cultura Económica, 1992, pp. 172 y ss. 
una herramienta metodológica útil para el estudio de los fenómenos sociales. El modelo de análisis funcional, tal como se explicó al iniciar el apartado tercero de este capítulo, no comparte la visión acerca de la sociedad que ha sido incorporada por el estructural/funcional, que para dicha escuela es una premisa a partir de la cual se fundamenta todo su sistema teórico. Aun cuando las diferencias y similitudes entre el estructural/funcionalismo y el modelo de análisis funcional han sido expuestas en las páginas anteriores, a continuación puede hacerse un resumen de sus líneas principales ${ }^{91}$ :

En cuanto a similitudes:

1. El estructural/funcionalismo y el modelo de análisis funcional elegido parten de los mismos conceptos básicos de fin y función originados en la primera (Merton), si bien la noción de función social ha sido precisada en el modelo de análisis funcional (Silva García).

2. La clasificación de las funciones sociales introducida por el estructural/funcionalismo (Merton), que refiere las funciones manifiestas y latentes, es adoptada por el modelo de análisis funcional.

3. El estructural/funcionalismo (Merton) y el modelo de análisis funcional seguido (Ferrajoli, Silva García, Cotterrell y Pacheco) comparten el interés y la preocupación teórica por distinguir entre los fines, que hacen parte del deber ser, y los hechos, que forman parten del ser.

\footnotetext{
${ }^{91}$ Aunque en seguida se van a mencionar a los autores que han definido los puntos principales, en tanto ellos fueron debidamente mencionados párrafos atrás, no se considera necesario volver a iterar las citas respectivas.
} 
Respecto de las diferencias:

1. La diferencia más importante radica en que para el estructural/funcionalismo las funciones cumplen un papel para preservar la estabilidad y la integración social (Parsons, Merton), mientras que en el modelo de análisis funcional eso es un sesgo ideológico, ya que las funciones pueden contribuir a acentuar la conflictividad social y la desintegración.

2. Para el estructural/funcionalismo las funciones sociales son positivas o negativas o, dicho en otras palabras, contribuyen a la adaptación del sistema (Merton), lo cual es reprobado de plano por el modelo de análisis funcional acogido.

3. El modelo de análisis funcional aceptado incluye en su clasificación de las funciones a las simbólicas (Gusfield, Silva García), que no son consideradas por el estructural/funcionalismo.

4. El estructural/funcionalismo utiliza la categoría de disfunción, que dada su subjetividad y sesgo es rechazada por el modelo de análisis funcional seguido.

5. El estructural/funcionalismo emplea el concepto de "exigencias funcionales", mientras que el modelo de análisis funcional lo rechaza.

6. Para el estructural/funcionalismo es necesario que un hecho sea reiterativo para que pueda hablarse de una función social, mientras que para el modelo de análisis funcional adoptado puede ser un hecho único, probablemente significativo, y generar funciones sociales.

7. El estructural/funcionalismo es una escuela o teoría de la sociología, el modelo de análisis funcional es un método de estudio que puede ser aplicado por distintas escuelas o corrientes de la sociología, sea que utilicen herramientas cuantitativas o cualitativas lo que no marca ninguna diferencia. 
8. La teoría estructural/funcionalista utiliza la noción de "no funciones", la cual no es admitida en el modelo de análisis funcional seguido aquí.

Los pros y contras, las ventajas y desventajas del estructural/funcionalismo y del modelo de análisis funcional se derivan lógicamente de lo planteado a lo largo y ancho de las páginas precedentes. No obstante, a modo de corolario, puede indicarse que el modelo de análisis funcional constituye un método útil para orientar el estudio de los fenómenos sociales, en este caso de las políticas de seguridad que han sido definidas desde el ámbito del derecho público, sin los sesgos y distorsiones que conlleva la perspectiva del estructural/funcionalismo. El análisis sociológico, en este caso sociojurídico del Derecho público, debe basarse en hechos constatables o verificables, no partir de juicios de valor que representan preconceptos, no demostrados empíricamente, pues ellos deforman el análisis e interpretación de los acontecimientos con fundamentos en los cuales son valoradas las políticas públicas.

Tal como se dijo el modelo de análisis funcional puede ser adoptado por distintas corrientes de la sociología y, por ende, de la sociología jurídica, pero es claro que varios de los autores considerados en este capítulo siguen la orientación propia de la teoría sociológica conflictualista (Silva García, Ferrari, Pacheco). Se ha adherido a dicha corriente páginas atrás, aun cuando el modelo de análisis funcional ha sido de interés como una herramienta metodológica para orientar o ilustrar el estudio de las políticas de seguridad fundas en el derecho público. 
En las décadas de los años 60 y 70 del siglo XX, cuando existía una notoria polarización en materia de ideologías políticas, la teoría estructural funcionalista, dado el evidente acento conservador que tenía, fue rechazada de plano por quienes eran partidarios de posiciones opuestas. Con un cierto tono dogmático, el estructural funcionalismo era rechazado de plano, en su totalidad, sin matices ni contemplaciones. Esto, probablemente, porque el mundo era percibido en blanco y negro. El correr de los años, sin duda una maduración política, pero también teórica, termino por erosionar las posiciones sectarias. Esto abrió las compuertas para que pudieran aprovecharse muchos de los elementos teóricos del estructural funcionalismo, en especial de la obra de Robert K. Merton, luego de despejarlos de los lastres representados en las creencias ideológicas que arrastraba consigo. Ello permitió que autores como Vincenzo Ferrari aprovecharan muchas de sus herramientas teóricas para la sociología jurídica, al subrayar la distinción entre la doctrina del estructural funcionalismo y el método de análisis funcional. Luego, la labor fue profundizada por Germán Silva García en la mayoría de sus trabajos teóricos y empíricos. Y, ahora, este texto procura sacar el mayor partido del análisis funcional para lograr las metas que se han propuesto.

Es además interesante que, precisamente, uno de los trabajos que no logró todo el éxito que merecía, dados los dogmatismos y el sectarismo que dominaban la época de su publicación, fue el de Lewis Coser acerca de las funciones del conflicto social. Rechazado por los estructural funcionalistas en razón al acento que le daba al conflicto social, denostado por los conflictualistas en vista de la importancia que le adjudicaba al estudio de las funciones sociales. Ahora, en cambio, libres de los prejuicios ideológicos señalados, la obra de Lewis Coser es la constatación de la viabilidad y utilidad de emplear el análisis funcional como método para 
adelantar un estudio de las políticas con las que ha pretendido enfrentarse en los últimos años el conflicto social $^{92}$.

El conflicto social en Colombia, en particular el conflicto armado interno, ha cumplido importantes funciones sociales, la gran mayoría de ellas latentes. Por ejemplo, el conflicto armado interno, como una constante histórica desde las guerras civiles del siglo XIX, pasando por el periodo de La Violencia, hasta el conflicto contemporáneo, ha contribuido al desarrollo de procesos de despojo y acumulación de la propiedad rural, aumentando la concentración de la tierra y generando inequidad social. También el conflicto armado interno ha cumplido la función social latente de contribuir a la agudización de las infracciones a los derechos humanos, so pretexto de erradicar la amenaza comunista. Ahora, los dos ejemplos anteriores, entre muchos que podrían ser expuestos, tienen el propósito de indicar que las funciones sociales del conflicto armado interno poseen también una alta relevancia, por cuanto las políticas públicas en materia de seguridad deberían buscar afectar o incidir y, en no pocos casos, neutralizar, esas funciones sociales.

Las políticas públicas pueden ser entendidas como los planes de intervención con los que el Estado o un gobierno, en forma pretendidamente organizada, esperan actuar para darle respuesta o atención a las problemáticas sociales, será el objeto al cual se aplicará el método de análisis funcional. Debe tenerse claro que las políticas pueden ser públicas o privadas, y que además hay tantas clases de políticas como escenarios sociales existen, por lo que se tienen políticas en educación, justicia, empleo, patrimonio cultural, medio ambiente, seguridad, etc. En

92 Lewis Coser. Las funciones del conflicto social, México D.F., Fondo de Cultura Económica, 1961, pp. 153 y ss. 
este escrito será únicamente materia de análisis la política de seguridad, además no en términos genéricos, sino sólo como política pública. Precisamente, en este campo específico, uno de los aspectos de mayor tensión y conflicto comparece con referencia a las políticas privadas de seguridad y las acciones con las que han intentado materializar sus objetivos.

Este capítulo ha hecho múltiples referencias a las funciones sociales relacionadas con el Derecho. Ello ha sucedido porque el tipo de análisis que pretende desarrollarse no sólo está vinculado a una cuestión propia de la ciencia política como son las políticas públicas. Ha ocurrido, sobre todo, por el interés particular que existe en el Derecho que, por una parte, en el articulado de la Constitución Política establece el marco jurídico general y fundamental que debe orientar la definición y ejecución de las políticas públicas y, por otra parte, en razón a que el Derecho con el concurso de sus normas reglamentarias materializa las concepciones y hace factibles las acciones que informan las políticas públicas. Es decir, el Derecho resulta indispensable para la ejecución de las políticas públicas, aun cuando ciertamente no todos los instrumentos de políticas públicas son de orden legal. 


\section{CAPÍTULO III}

\section{POLÍTICAS PÚBLICAS EN SEGURIDAD}

\section{Y ANÁLISIS FUNCIONAL}

Este capítulo abarca dos ejes fundamentales. El primero de ellos se refiere al conflicto armado interno, una variable que incide de manera directa sobre la definición y papel de las políticas públicas en seguridad. El segundo eje comprende una descripción de las principales políticas estatales en materia de seguridad que, en los últimos años, han sido ejecutadas. Esto incluye una revisión de las regulaciones jurídicas, habida cuenta que el Derecho es uno de los instrumentos más importantes para la materialización política de la acción pública en un campo. Tarea que, además, estará acompañada de un análisis funcional de las políticas estatales en seguridad.

1.- El Conflicto Armado y la Crisis de Seguridad.-

La caracterización del fenómeno de la violencia política y del estado de inseguridad que padece Colombia, desde hace más de cincuenta años, es una cuestión de alta relevancia. Finalmente, esa caracterización, es decir, la interpretación asumida sobre la naturaleza de la 
problemática que se va a enfrentar, resultaría definitiva para configurar las políticas públicas de seguridad. Dicho en otras palabras, determinar cómo se entiende el fenómeno de violencia es decisivo, pues esa comprensión va a marcar el tipo de respuesta o reacción que se va a proponer, o sea, las políticas públicas que se van a postular.

En el ámbito anterior, desde el mismo título del apartado se ha adoptado una posición, pues se ha hecho referencia a un "conflicto armado", lo que en todo caso le demanda al texto introducir algunas explicaciones. Esto descarta definiciones como la más tradicional que hace referencia a situaciones de "bandolerismo" u otras, más recientes, que aluden a una "amenaza terrorista”. En seguida se harán las explicaciones indispensables.

El substrato envuelto en el debate en torno a las tres caracterizaciones anteriores: bandolerismo, amenaza terrorista y conflicto armado, es el rechazo o el reconocimiento de la índole política de la problemática de violencia estudiada. Esto está directamente relacionado con la noción decimonónica del delito político, engendrada durante las revoluciones liberales de los siglos XVIII y XIX, en las que la rebelión o la sedición tenían una connotación de altruismo y nobleza, que envolvía la idea de la utilización de la violencia como medio para el logro del progreso y la transformación social. De allí proviene también la idea, ampliamente difundida y defendida por los teóricos del liberalismo, en cuanto a que la rebelión contra la tiranía es un derecho.

Sin embargo, la anterior constituye una visión idealista en torno al delito político, no compartida por este texto. Semejante asociación entre delito político y, por otra parte, nobleza y 
altruismo, entendidos como la acción motivada por buenos sentimientos y el último como una actitud de hacer el bien a otros aún a costa del sacrificio propio, ambas desinteresadas y solidarias, comporta un juicio de valor que, por tanto, tiene dos cualidades: es algo subjetivo y es relativo. La subjetividad y relatividad del concepto de delito político comentado, esto es de la concepción idealista citada, implica que no necesariamente lo que para unos es algo noble o altruista lo será para otros. En realidad, todo depende de la posición ideológica de quien define la acción como noble o altruista o la reprueba ${ }^{93}$.

La anterior, que constituye una mirada tradicional sobre el delito político, es inverificable en términos empíricos, además de irrelevante ${ }^{94}$. No puede ser constatada en forma empírica puesto que se trata de una finalidad u objetivo, es decir, la nobleza o el altruismo no son ni falsos ni verdaderos en cuanto metas, pese a que pueden ser bastante discutibles. Es irrelevante, precisamente, dada su enorme carga de subjetividad y relatividad.

Al contrario, se pensaría que un delito es político en tanto que se encuentra motivado u orientado a subvertir o lesionar el orden político existente. Motivación que, además, puede ser identificada mediante un análisis de la racionalidad de las acciones, valga decir, de la idoneidad que posean para alcanzar el propósito de afectar o derribar el sistema político o el gobierno ${ }^{95}$. En ese sentido, Max Weber explica que las acciones sociales son racionales e irracionales, y las

93 Germán Silva García. "Delito político y narcotráfico", en La problemática de las drogas. Mitos y realidades, Bogotá, Universidad Externado de Colombia y Programa "Enlace" del Ministerio de Comunicaciones, 1998, p. 67.

${ }_{94}$ Compartida por la mayoría de los autores, esa visión tradicional puede ser constatada, por ejemplo, en Denis Szabo. Criminología y política en materia criminal, México D.F., Siglo XXI, 1980, p. 176.

${ }^{95}$ Del concepto anterior, Silva García. "Delito político, cit., pp. 68 y ss. 
racionales se entienden como aquellas orientadas por fines, pero donde son desplegadas actuaciones que deben ser idóneas para alcanzar esas finalidades ${ }^{96}$.

La idea de bandolerismo con la que de manera generalizada se pretendía identificar a los miembros de guerrillas en Colombia, sobre todo, a partir de los años 50 del siglo XX, respondía a intereses políticos, fundamentalmente propagandísticos. Se trataba de desacreditar a esas guerrillas, tildándolas a sus miembros de bandoleros, para asociarlos a la delincuencia común. Se intentaba, desde el punto de vista del entendimiento tradicional sobre el delito político, que las cualidades de altruismo y nobleza no pudieran ser reconocidas o atribuidas a tales insurrectos.

A lo anterior se sumaba, así mismo, una consideración de orden práctico. El objetivo era poder aplicar a los convictos, de manera simultánea, las penas contempladas para distintos delitos comunes, como el homicidio, el secuestro, el porte ilegal de armas, el daño a bien ajeno, etc., las cuales no podían imputarse a los reos de los delitos de rebelión. Lo antes explicado, en razón a que el tipo penal de rebelión consignado en el Código Penal de 1980 subsumía cualquier otra vulneración a intereses jurídicos distintos, ya que esos otros delitos se convertían en medios para la realización de la rebelión. Cuestión a la que se agregaba el hecho de que el delito de rebelión tenía una pena bastante baja. Esto, al menos, hasta que la Corte Constitucional se pronunció sobre la inconstitucionalidad del artículo 127 del Código Penal, argumentando al respecto que la subsunción amplia de todas las infracciones penales dentro del tipo de rebelión conducía a la impunidad $^{97}$.

\footnotetext{
${ }^{96}$ Weber. Economía, cit., p. 5 y ss.

97 La Corte Constitucional. Sentencia C-456 de 1997, Magistrados Ponentes Jorge Arango Mejía y Eduardo Cifuentes Muñoz, señaló: "El artículo $2^{\circ}$ de la Constitución consagra como uno de los fines esenciales del Estado el asegurar la "convivencia pacífica y la vigencia de un orden justo". Es contraria a la primera de estas dos finalidades una norma que permite la comisión de toda clase de delitos y asegura su impunidad, o mejor, que convierte el delito (todos los delitos) en arma política. Y no contribuye a la vigencia de un orden justo, la norma que impide que se investiguen los delitos y se
} 
En el periodo de La Violencia (1946-1964), sin duda, concurrieron expresiones de violencia que respondían a la idea de bandolerismo. Numerosos grupos de bandoleros operaron en el país, pues actuaban sin el propósito de transformar el orden político, sino motivados por intereses particulares, como la venganza o el lucro personal, incluso, aun cuando también echaran mano de una retórica de sectarismo político ${ }^{98}$. A su vez, la índole de los asaltos o ataques que cometían concordaban, no con propósitos políticos, sino con las pretensiones antes indicadas. Empero, al tiempo, en la misma época de La Violencia, igualmente, operaron grupos de guerrilla liberales y comunistas que obraban guiadas por motivaciones políticas. En los mismos términos, los movimientos guerrilleros contemporáneos, como las FARC-EP o el denominado Ejército de Liberación Nacional -ELN-, han actuado por móviles políticos. El hecho de que eventualmente los grupos guerrilleros recurran a prácticas propias del bandolerismo o, si se quiere, de la delincuencia común, como el robo para provecho personal, las "sociedades" con bandas de secuestradores comunes o el narcotráfico, no desdice de la naturaleza política de sus estructuras.

En consecuencia, las alusiones a "cuadrillas de bandoleros" u otras similares, tan comunes en el discurso militar sobre la subversión en Colombia, tienen fines propagandísticos que apuntan a desacreditar a las guerrillas, pero no corresponden a la realidad empírica del fenómeno que se enfrenta.

castigue a los delincuentes. Las normas que se examinan establecen un privilegio inaceptable para quienes, por su propia voluntad, incurren en los delitos de rebelión o sedición: el violar impunemente todas las normas penales."

${ }_{98}$ Germán Guzmán, Orlando Fals Borda y Eduardo Umaña Luna. La Violencia en Colombia, 2ª ed., T. I, Bogotá, Tercer Mundo, 1963, pp. 143 y ss. 
El concepto de amenaza terrorista, más contemporáneo, ha tenido casi siempre, también en este caso, usos puramente propagandísticos. El calificativo de terrorista posee una considerable carga negativa. Dado que, además, la acción terrorista, al lado de los actos de crueldad o barbarie, en general se ha considerado ajena a los delitos políticos, incluso los actos terroristas suelen ser excluidos de beneficios como amnistías o indultos, pues usar la expresión apunta a negar el carácter político de las infracciones cometidas con propósitos de ese tipo. También, la noción de terrorismo es incompatible con los elementos que definen el concepto tradicional de delito político, o sea con la nobleza y el altruismo, luego de nuevo las acciones de los infractores estarían despojadas de todo sentido político.

Si adoptamos algún tipo de concepto sociológico sobre el terrorismo, se tendría por tal las acciones orientadas a generar pánico y zozobra dentro de la población, como resultado de la utilización indiscriminada de la violencia. En concordancia con la acepción anterior, no puede afirmarse que las FARC-EP o el ELN son organizaciones terroristas. Es posible que, de manera ocasional, hayan ejecutado acciones terroristas, pero el conjunto de sus operaciones no encajan dentro de la definición de terrorismo expuesta. Así mismo, también cabe agregar que el terrorismo acostumbra a tener fines políticos, por ende, correspondería a un tipo singular de delito político. Con lo que no comulga el terrorismo, como modalidad de acción política, es con la noción tradicional del delito político, pues probablemente éste no tiene nada que ver con la nobleza y el altruismo, aunque eso depende del "cristal con que se mire".

El terrorismo es, en realidad, una táctica. Como cuando los grupos paramilitares de las AUC llegaban a una zona y ejecutaban varios asesinatos, de manera indiscriminada y, además, 
con particular crueldad o sevicia. En esos casos el objetivo era generar un estado de miedo generalizado en la población a efectos de dejar a la guerrilla sin apoyo y, de modo paralelo, asegurarse de obtener la obediencia incondicional para sus directrices. Otro tanto ocurre con llamadas "Bacrim" que actúan hoy en Buenaventura y recurren a una violencia despiadada, en virtud de la cual los cuerpos son descuartizados, todo con el objeto de atemorizar a los pobladores para imponer la "ley del silencio", es decir, para conseguir que las gentes no colaboren con la policía y, por otra parte, también para que acaten sus órdenes, como las relativas al pago de extorsiones, etc. La diferencia entre el accionar de unos y otros radica en la motivación política de los primeros, dentro de una concepción de guerra antinsurgente, mientras que los segundos carecen de todo objetivo político.

Las guerrillas de las FARC-EP y del ELN son organizaciones de filiación comunista, la primera más ortodoxa, la segunda con un marcado acento castrista. En ambos casos, con ligeras variantes, a la larga no sustanciales, buscan imponer un nuevo régimen político y constitucional con la instauración de un Estado socialista, al estilo de las naciones de Europa o de Cuba, es decir, con los rasgos de un régimen stalinista. Por tanto, es claro que poseen y actúan guiadas por un proyecto político que supone derribar el orden constitucional y legal vigentes para, en su reemplazo, imponer un Estado totalitario con los rasgos del llamado "socialismo real", el cual pretenden realizar, luego de alcanzar el poder político mediante las acciones propias de la guerra insurgente.

Una cuestión práctica derivada de la caracterización de la problemática confrontada tiene que ver con la naturaleza de los medios que se le oponen. Si se trata de un conflicto armado 
interno la utilización del Derecho Internacional Humanitario -DIH-, dada la índole bélica del conflicto, sería la más apropiada. Con todo, en estos casos, en ocasiones se utiliza el DIH, en otros el Derecho penal y en algunos más son combinados ambos. El uso del Derecho penal se entiende bajo el supuesto de que se trata de una problemática interna, lo cual lleva a los agentes del Estado, por regla general, a tratar a los rebeldes o subversivos como delincuentes. Pero el DIH goza de un ámbito de aplicación que cubre tanto los conflictos externos, esto es, las guerras clásicas regulares entre Estados, como los conflictos armados internos. La situación plantea varios problemas a considerar.

Se ha discutido si el Derecho penal debe ser utilizado para enfrentar a los insurrectos partícipes de un conflicto armado interno. Por una parte, si el conflicto es un tipo particular de guerra, la preguntaría sería ¿si resulta racional, valga decir, si puede considerarse idóneo, emplear medios penales para alcanzar los fines perseguidos o, al contrario, no sería más apropiado recurrir al Derecho de la guerra, es decir, al DIH? Si se enfrenta una situación de guerra, de la que el conflicto armado interno es una variante, pues entonces lo lógico sería usar el DIH, al menos de manera prioritaria y preponderante, para enfrentar el fenómeno. El quid del asunto, como ha sido recordado por Luigi Ferrajoli, es que el Derecho penal es un instrumento para luchar contra "criminales", no para combatir "enemigos", razón por la cual el Derecho penal termina distorsionado cuando se le impone un papel que no le corresponde ${ }^{99}$.

De otra parte, se ha advertido que la utilización del Derecho penal para confrontar a los rebeldes o insurrectos termina por pervertir al Derecho penal. Ya que el mismo no es un instrumento apropiado para neutralizar la subversión, a la postre termina siendo deformado, con

${ }^{99}$ Luigi Ferrajoli. Derecho y razón, $2^{\text {a }}$ ed., Madrid, Trotta, 1997, pp. 832 y ss. 
la aspiración de convertirlo en una herramienta represiva eficaz. Esto perjudica a la mayoría de la población y afecta sus derechos fundamentales, en tanto el Derecho penal está contemplado para regular las relaciones sociales entre los ciudadanos de un Estado.

Sin embargo, aunque en buena parte resulte irracional, el Derecho penal ha sido tradicionalmente utilizado para intentar la destrucción de los grupos alzados en armas. Por ello mismo, la política penal o política criminal ha intervenido en forma activa, en el ámbito de las políticas públicas, con el objeto de concebir o diseñar herramientas para atacar la rebelión o insurrección. De allí que las medidas de política penal sean examinadas en este texto, pese a que en estricto sentido son las políticas públicas en seguridad las que constituyen su campo de conocimiento.

Por su parte, las políticas de seguridad encuentran un mejor canal de realización en las normas del DIH. El DIH no fue instituido para acabar o para reducir la guerra, sino para hacerla mejor. Si la guerra es la continuación de la política por otros medios, como lo indicara Karl Von Clausewitz, teórico clásico de la guerra, pues el DIH tiene como propósito central que los objetivos políticos que se persigan puedan ser logrados dentro de las mejores condiciones ${ }^{100}$. Una faceta de ello consiste en restringir, eliminar o amortiguar los daños ocasionados por la guerra, lo que equivale a cumplir con una finalidad humanitaria.

La guerra, al igual que la política, aspira a conseguir que el bando ganador se apropie del poder. Ya de un modo específico, en la guerra moderna se busca eliminar el mando político y militar del ejército rival, la interrupción de sus líneas de comunicación y la destrucción o

${ }^{100}$ Karl von Clausewitz. De la guerra, Barcelona, Mateu, 1972, p. 58. 
conquista de sus fuentes de recursos, como pasos necesarios para alcanzar el triunfo final.

Ocasionar sufrimiento, lesionar la vida o la integridad física de la población civil o provocar la destrucción generalizada e indiscriminada de bienes no son objetivos racionales de la guerra. Empero, la lucha ocasiona daños en los adversarios, a veces excesivos e innecesarios desde el punto de vista de los objetivos políticos principales que se intentan alcanzar, sin contar aquellos producidos en la población civil, que tienen aún menos justificación plausible. Entonces, a fin de limitar esos daños, compareció primero el Derecho de gentes y luego, después de la Segunda Guerra Mundial, paralelo a la creación de la Organización de Naciones Unidas, los Derechos Humanos y el Derecho Internacional Humanitario ${ }^{101}$.

El DIH tiene su origen en dos fuentes: el Derecho de Ginebra que se consolidó con la aprobación de los protocolos I y II, el cual tiene como empeño distinguir entre combatientes y no combatientes, asistir a las víctimas y a la población civil afligida; y la segunda el Derecho de La Haya que regula la conducción de las hostilidades y delimita la utilización de los métodos de guerra $^{102}$. Para la época de la Segunda Guerra Mundial existían ya varios instrumentos, pero el Derecho internacional ha procreado en forma constante otros instrumentos relativos al trato a la población civil, la tipificación de delitos de lesa humanidad, el trato a combatientes prisioneros, el establecimiento de jurisdicciones internacionales para el juzgamiento de los crímenes de guerra, la prohibición de torturas o tratos crueles, la veda a la utilización de determinadas armas que ocasionan graves y excesivos daños físicos, etc.

101 Jorge Enrique Carvajal Martínez. La Seguridad Dentro del Estado de Garantías, Bogotá, ILSA, 2008, pp. 31.32 y 56. En esa dirección, se encuentran el Convenio de Ginebra para aliviar la suerte que corren los heridos, los enfermos y los náufragos de la fuerzas armadas en el mar (Convenio II); el Convenio de Ginebra relativo al trato debido a los prisioneros de guerra (Convenio III) y el Convenio de Ginebra relativo a la protección debida, a las personas civiles en tiempo de guerra (Convenio IV).

102 Alejandro Valencia Villa. La humanización de la guerra, Bogotá, Tercer Mundo y Uniandes, 1992, pp. 23 y ss. 
Un principio fundamental del DIH apunta a que las partes involucradas en un conflicto deben en todo tiempo diferenciar entre civiles y combatientes, siendo que los primeros no pueden contar entre los objetivos militares, lo que corresponde al principio de "Distinción". Así el Derecho Internacional Público está destinado a proteger la vida de las personas y a la humanización de las confrontaciones bélicas ${ }^{103}$.

Cuando concurren conflictos armados internos, con harta frecuencia en razón a los riesgos "naturales" que envuelve el conflicto, se vulnera el DIH, transformándose a la población civil en objetivo militar, víctima de coacciones, desplazamiento, homicidio, abuso sexual y despojo de sus bienes. Debido al cuadro anterior, los poderes estatales han aprobado instrumentos de orden policivo o de carácter excepcional, con el objetivo de enfrentar el conflicto entre Estados o la confrontación interna, para garantizar la seguridad y restablecer el monopolio de la autoridad legítima dentro de su territorio, a través de las instituciones encargadas del control del orden público ${ }^{104}$.

De manera paralela, las medidas extraordinarias y las adaptaciones legislativas continuas y permanentes configuran un nuevo orden jurídico que esconde un novedoso paradigma de gobierno o de Estado, denominado por Giorgio Agamben "Estados de Excepción." ${ }^{105}$ En el

${ }^{103}$ El Derecho Internacional de los Derechos Humanos se agrupa en tres categorías: los derechos humanos, el Derecho internacional humanitario y el Derecho penal internacional.

${ }^{104}$ Para el caso colombiano desde el primer gobierno de Alvaro Uribe Vélez 2002-2006, dentro de la estrategia de la Política de Defensa y Seguridad Democrática, se propuso la creación de una red de informantes que, a cambio de recompensas, otorgaría información a los organismos de seguridad del Estado para enfrentar los grupos armados ilegales, Carvajal Martínez. La Seguridad, cit., p. 84.

${ }^{105}$ Giorgio Agamben. Estado de Excepción, Buenos Aires, Adriana Hidalgo, 2003, pp. 17 y ss. 
ámbito del derecho público las medidas de excepción han sido consideradas de orden meramente político.

En los conflictos armados internos la sociedad invoca el DIH, por cuanto esta normatividad reglamenta circunstancias como las referidas al uso de armas, el trato que debe dispensarse a los combatientes. El pacto internacional de derechos civiles y políticos permite a los Estados miembros desarrollar medidas para superar estados de peligro, pero consagra los siguientes límites: el deber de proteger el derecho a la vida; la obligación de que nadie puede ser sometido a torturas, ni a tratos crueles, inhumanos o degradantes; el principio de legalidad supone que nadie será condenado por actos u omisiones que en el momento de cometerse no fueran delictivos según el derecho nacional o internacional y, por último, la protección a la libertad de pensamiento.

Existen derechos que admiten restricciones, particularmente en situaciones de alteración del orden público o de afectación de la seguridad nacional como la libertad de expresión, la de asociación, de reunión y de circulación. En tales eventos, resulta imprescindible recurrir a los principios de legalidad y necesidad, a fin de moderar las intervenciones y contener los riesgos de abuso $^{106}$. También existen derechos absolutos que no admiten limitación alguna, como es el caso del derecho a la vida, la prohibición de la esclavitud y el acceso a la justicia.

${ }^{106}$ El principio de legalidad obliga al Estado a señalar por medio de la Ley las conductas que se restringen. El principio de necesidad exige que se constate una situación real antes de declarar las medidas extraordinarias, es decir, la excepción debe estar justificada en hechos que pongan en riesgo el régimen constitucional, Carvajal Martínez. La Seguridad, cit., pp. 54 a 58. 
Las normas del DIH contemplan un marco jurídico que regulará y, a la vez, establecerá una restricción política a las intervenciones que hipotéticamente pueden desarrollarse en razón de la concepción y aplicación de las políticas de seguridad. Constituyen una barrera para definir las medidas y acciones de las políticas de seguridad. En conclusión, las normas del DIH deben ser punto de referencia obligado al determinar las políticas de seguridad.

Con todo, agentes del Estado colombiano con alguna repetición, a veces en formas que no podía responder más que a verdaderas políticas institucionales, y con bastante frecuencia las organizaciones guerrilleras, han transgredido el DIH. En negociaciones previas a las desarrolladas durante el Gobierno del presidente Juan Manuel Santos (2010-2014), las organizaciones guerrilleras se han negado a aplicar el DIH. El Estado, no obstante, tiene la obligación de definir sus políticas de seguridad en concordancia con el DIH e, inclusive, debería tomar medidas preventivas y proactivas para evitar los riesgos de infracciones al DIH.

El actual movimiento guerrillero es un producto directo del periodo de La Violencia, en una época donde las dinámicas del conflicto hacían absoluto caso omiso de las normas del DIH que, en parte, estaba aún en construcción. La Violencia se había iniciado por motivos de sectarismo político, alentada desde los gobiernos conservadores de Mariano Ospina Pérez (19461950) y Laureano Gómez (1950-1953), que procuraron salvar su posición minoritaria con el empleo generalizado de la persecución y la violencia política, además de clausurar instituciones democráticas y alterar o manipular otras ${ }^{107}$. Lo anterior, aun cuando la violencia sería utilizada

107 Daniel Pecaut. Orden y violencia: Colombia 1930-1954, Vol. II, Bogotà, CEREC y Siglo XXI, 1987, pp. 525 y ss. 
como una estrategia para apoderarse de las tierras de los rivales políticos, constituyéndose en la principal motivación del conflicto ${ }^{108}$.

En 1946 Mariano Ospina Pérez accedió a la presidencia aprovechando que el Partido Liberal había arribado dividido a las elecciones, entre el candidato de la corriente de derecha Gabriel Turbay y el candidato de la tendencia de izquierda Jorge Eliecer Gaitán. Luego, de manera temprana, se iniciaron en la mayor parte del país los actos de violencia y persecución contra los liberales, aupados en la complicidad del Gobierno. En 1948 el asesinato del dirigente liberal Jorge Eliécer Gaitán agrava aún más la situación, tanto por la agudización de las persecuciones conservadoras, como por el alzamiento armado de grupos liberales en varias regiones, como los Llanos, Santander y Tolima. En 1950 se instaura la dictadura civil de Ospina Pérez, cuando ordena la clausura del Congreso de la República, al temer que la mayoría parlamentaria liberal lo enjuicie políticamente. Ese mismo año es elegido Laureano Gómez, siendo candidato único a la presidencia de la República, habida cuenta que el candidato liberal renuncia por falta de garantías, luego de varios asesinatos de dirigentes liberales. Del modo descrito, la dictadura se prolonga.

En esos años, bandas armadas conocidas como “pájaros” son alistadas como grupos paramilitares para activar las persecuciones violentas, realizadas con intervención de las Fuerzas Armadas ${ }^{109}$. El Ejército era de inclinación conservadora, mientras que la policía fue purgada para expulsar a los liberales, y a la vez reforzada con "chulavitas", fanáticos conservadores, que se empeñaron a fondo como cómplices de la violencia ejecutada. El golpe militar contra el

\footnotetext{
108 Daniel Pecaut. "Reflexiones sobre el fenómeno de La Violencia", en Once ensayos sobre La Violencia, Bogotá, CEREC y Centro Gaitán, 1985, pp. 183 y ss.

${ }^{109}$ Guzmán, Falsa Borda y Umaña Luna. La Violencia, cit., pp. 165 y ss.
} 
presidente designado Roberto Urdaneta en 1953, por parte del general conservador Gustavo Rojas Pinilla, si bien genera un breve periodo de paz motivado por las expectativas de pacificación y por la amnistía a los militantes de las guerrillas, no deja de tornarse en una falsa ilusión ${ }^{110}$. Varios de los jefes guerrilleros desmovilizados son asesinados.

La situación política descrita alentó, sobre todo desde 1948, la formación de guerrillas liberales y comunistas que, esencialmente, se conforman como autodefensas campesinas para asegurar la sobrevivencia frente a las persecuciones oficiales. Protegidas por las autodefensas los campesinos desplazados se refugian en zonas de colonización. Durante el periodo de La Violencia se calculan alrededor de 300 mil muertes. Sólo con la instauración del Frente Nacional, que condensa el acuerdo político de los partidos liberal y conservador para alternarse en el poder durante 16 años, se alcanza una pacificación relativa, pese a la cual subsisten en zonas remotas, algunas autodefensas comunistas, las cuales no juegan un papel militar activo. Estas autodefensas no se habían desmovilizado del todo, pues durante la dictadura de Gustavo Rojas Pinilla la población que protegían había sido blanco de ataques, como el sucedido en Villarica (Tolima), lo que las hacía desconfiar del Estado. Después, en el transcurso del Gobierno conservador de Guillermo León Valencia (1962-1966), como resultado de la instigación del dirigente conservador Álvaro Gómez Hurtado se produce la Operación Marquetalia.

El ataque de Marquetalia provoca el repliegue de la autodefensa guerrillera a antiguas regiones de influencia comunista, durante la época de La Violencia. Esto dará origen a la conformación de las FARC-EP. El éxito de las FARC para sostenerse e, incluso, avanzar con

${ }^{110}$ Sobre la amnistía de 1954, Alfredo Molano. Amnistía y violencia, Bogotá, CINEP, 1978, pp. 14 y ss. 
ventaja sobre las Fuerzas Armadas en algunos periodos, recae en los conocimientos y pericia que adquirieron durante la época de La Violencia sobre las estrategias y tácticas de la guerra de guerrillas, junto a las bases de apoyo popular que se habían formado en ese mismo periodo, cuando como resultado de las persecuciones había una fuerte resistencia y animadversión contra las Fuerzas Armadas. Estas circunstancias marcan una gran diferencia con otros movimientos guerrilleros de tipo foquista, los cuales inspirados en Ernesto "Che" Guevara, fracasaron estrepitosamente en otros países latinoamericanos, como la propia aventura del mismo "Che" Guevara en Bolivia. De manera adicional, la región del Sumapaz, una zona de alto valor estratégico, pues constituye un nudo montañoso desde el cual se puede acceder a varios departamentos e, incluso, a los arrabales de la ciudad de Bogotá, había parte de los territorios de influencia comunista durante la época de La Violencia. Con posterioridad, la región del Sumapaz jugaría un papel clave en el éxito de las operaciones de la guerrilla.

Como se afirmó con anterioridad, durante el Frente Nacional se fraguó una pacificación relativa. Sin embargo, la misma comprendía a liberales y conservadores, no a otros sectores, que además fueron excluidos del pacto. Algunos rezagos de guerrillas o grupos bandoleros que no se habían desmovilizado, aislados del apoyo de la población civil, fueron aniquilados ${ }^{111}$. Las guerrillas comunistas, constituidas en autodefensas, en cambio se mantuvieron, aunque su papel estaba limitado a la defensa de los campesinos en las zonas de colonización, en la frontera agrícola, donde se localizaban. Tales autodefensas no ocupan zonas estratégicas en términos económicos, sociales o políticos. De allí que la mencionada Operación Marquetalia hubiese sido un error clave, pues esas autodefensas no constituían un problema serio. Probablemente con una

111 Gonzalo Sánchez y Donny Meertens. Bandoleros, gamonales y campesinos, $3^{a}$ ed., Bogotá, El Áncora, 1985, pp. 62 y ss. 
campaña pacífica de inversión social y acciones económicas para integrar esos territorios al mercado agrícola, junto a medidas jurídicas y sociales para asegurar la titulación de las tierras a los campesinos, se habría podido neutralizar el problema. En cambio, la Operación Marquetalia, que fue un fracaso militar, representó un desastre político, pues se convirtió en el detonante que dio origen a las FARC-EP y a 50 años de guerra de guerrillas, con todos los daños asociados.

Con posterioridad, aunque las FARC-EP crecieron y ampliaron su influencia, conservaron su papel de fuerza de autodefensa. Realmente, en términos políticos y militares constituían un movimiento político y armado que protegía los derechos de pequeños propietarios rurales $^{112}$. Sólo hasta 1982, cuando celebra la VII Conferencia, decide abandonar ese rol al diseñar un plan realista para tomarse el poder.

El plan de acción de las FARC-EP para tomarse el poder comprendía tres etapas. Durante la primera, que se alcanzó en el Gobierno del presidente Belisario Betancur Cuartas (1982-1986), la guerrilla debía multiplicar sus frentes, a partir de los existentes, y hacer presencia en zonas económicas estratégicas. Durante la segunda etapa, la guerrilla debía lograr la capacidad para hacer grandes concentraciones coyunturales de efectivos para realizar ataques contra posiciones fijas de las Fuerzas Armadas, lo que fue logrado en el curso del Gobierno del presidente Ernesto Samper (1994-1998). La tercera etapa significaba tender las condiciones adecuadas para transformar la guerrilla en un ejército regular y tomarse el poder. Los objetivos de la etapa anterior no fueron coronados, ya que desde el Gobierno del presidente Andrés Pastrana Arango (1998-2002), lo que se profundizo desde el primer Gobierno del presidente Álvaro Uribe Vélez (2002-2010), en razón de la modernización en armamento de las Fuerzas Armadas, las mejoras

${ }^{112}$ William Ramírez Tobón. Estado, violencia y democracia, Bogotá, Tercer Mundo e IEPRI, pp. 57 y ss. 
en sus servicios de inteligencia y en la capacidad operativa, pero sobre todo debido a la utilización permanente de medios tecnológicos para la detección de los movimientos y comunicaciones de la guerrilla, se hizo imposible que la guerrilla pudiera hacer concentraciones de combatientes sin ser detectados. Esto obligó a la guerrilla a volver a tácticas que empleaba antes de la ejecución de la primera etapa, conforme a las cuales sólo podía moverse en muy pequeñas escuadras o cuadrillas ${ }^{113}$.

No obstante, lo anterior no significó la destrucción o una derrota decisiva de la guerrilla. Durante el primer Gobierno del presidente Álvaro Uribe Vélez el Estado recupera el control sobre varias carreteras de importancia fundamental, reduce sustancialmente la capacidad de perturbación de la guerrilla, y obliga a la guerrilla a replegarse a lo profundo de la selva o de aisladas regiones montañosas. Sin embargo, la guerrilla se retira ordenadamente, conservando aún la mayoría de su fuerza. El Ejército lanzó el "Plan Patriota" contra el corazón de las FARCEP en el Departamento del Caquetá, con el fin de exterminar a la guerrilla, pero los objetivos no se alcanzaron, para en cambio sufrir más de cuatro mil bajas entre las minas antipersona y los enfermos de leishmaniosis, mientras la guerrilla se retiró de manera ordenada y con pocas bajas.

El ELN estuvo a punto de ser aniquilado por el Ejército en 1973, a raíz de la Operación Anorí, cuando incursionó en una zona alejada de su territorio y bases de apoyo. Tuvo entonces grandes pérdidas y aunque el Ejército no le propinó el golpe final, quedó al borde de la desaparición. Sin embargo, la extorsión a la compañía que construía el oleoducto Caño-Limón Coveñas le otorgó los recursos con los cuales pudo renacer de la que parecía su agonía final y

\footnotetext{
${ }^{113}$ Germán Silva García. "La décima es la vencida. El nuevo proceso de paz con las FARC", en Nueva Época, No. 39, Bogotá Universidad Libre, 2012, pp. 73 y ss.
} 
recuperarse. Desde entonces, ha padecido de algunas crisis, no posee una gran cantidad de efectivos y su presencia en zonas estratégicas es bastante más limitada en comparación con las FARC-EP.

A mediados de los años 80 en Colombia podían identificarse ocho grupos guerrilleros con orientaciones ideológicas diversas. Las Fuerzas Armadas Revolucionarias de Colombia -FARCEP- de inclinación comunista ortodoxa, que durante muchos años estuvo bajo la dirección política del Partido Comunista (prosoviético), y notoria ascendencia campesina, que representaba el grupo más importante por su penetración en zonas económicas estratégicas y poderío militar; el Ejército de Liberación Nacional -ELN-, comunista, de inspiración guevarista y conformado en sus inicios por estudiantes universitarios; el Ejército Popular de Liberación -EPL- de pensamiento maoísta, integrado por disidentes del Partido Comunista; el Partido Revolucionario de los Trabajadores -PRT- que era un movimiento armado menor, centrado en los departamentos de Sucre y Bolívar; el Movimiento Indígena Guerrillero Quintín Lame conformado por indígenas, el cual operaba en el departamento del Cauca; el Movimiento 19 de abril -M19-, de izquierda y nacionalista, con presencia urbana, formado por disidentes de las FARC y antiguos miembros de la Alianza Nacional Popular -ANAPO-; un pequeño grupúsculo guerrillero denominado Autodefensa Obrera -ADO-, con presencia únicamente urbana de orientación anarco-troskista, que principalmente realizó algunos asesinatos selectivos; la Corriente de Renovación Socialista, una disidencia del ELN, con operaciones puntuales en la Costa Atlántica.

Pero la violencia provino sobre todo del narcotráfico con sus prósperas bandas y sus dirigentes involucrados en la vida social y política del país. La etapa más intensa de esta guerra 
tuvo lugar antes de las elecciones presidenciales de 1990, su momento más dramático se presentó cuando el líder Luis Carlos Galán, precandidato a la presidencia de la República fue asesinado durante una manifestación política. La situación de violencia y de incertidumbre institucional que vivió la sociedad colombiana durante el periodo electoral mencionado motivó algunas marchas estudiantiles por las principales calles de Bogotá. Más de quince mil personas reclamaron la renovación institucional a través de la creación de una nueva Constitución. De la suma de todos estos factores surgió la Asamblea Nacional Constituyente que dio lugar a la Constitución de 1991. No obstante, la promulgación de la Constitución de 1991, la violencia política continuó durante toda la década de los noventa y se acrecentó en la segunda mitad de la misma.

El primer grupo insurgente que se acogió a un proceso de desmovilización fue el M19, bajo el Gobierno de Virgilio Barco (1986-1990), proceso que culminó el 8 de marzo de 1990. Los procesos de negociación política y desmovilización con el EPL, el PRT, el Quintín Lame y la Corriente de Renovación Socialista del ELN se saldan de manera exitosa, pese a que todos ellos son víctimas de atentados y acciones que buscan sabotear los acuerdos. En la década de 1990 pudieron, entonces, materializarse acuerdos exitosos de negociación que estuvieron seguidos de una nueva Constitución, con la que se buscaba proveer un nuevo marco político social e institucional al país. Sin embargo, los actores que persistieron en la vía armada fueron los grupos guerrilleros FARC-EP y ELN, junto a los grupos paramilitares, quienes emprendieron una confrontación que conllevo a la degradación de la guerra, convirtiendo a la sociedad civil en la principal víctima del conflicto armado. 
Las FARC-EP, en especial, y el ELN no habían participado con seriedad y una efectiva voluntad de conseguir un acuerdo de paz en los procesos de negociación que antecedieron al actual, llevado adelante entre el Gobierno del presidente Juan Manuel Santos y las FARC-EP. Los procesos que fueron adelantados por los gobiernos de Belisario Betancur y Andrés Pastrana Arango son utilizados para lograr ventajas políticas y militares, cometidos éstos que se alcanzaron con notable eficacia por parte de las FARC-EP. Sin embargo, la situación militar y política, la cual ya fue descrita, que ha acompañado a las negociaciones en el transcurso del Gobierno de Juan Manuel Santos es favorable a un acuerdo de paz. Así mismo, las condiciones en las que se realizan las negociaciones de La Habana, a diferencia de lo ocurrido en otros procesos, no facilita que las conversaciones de paz puedan ser manipuladas para obtener ventajas políticas o militares a favor de las FARC-EP. Lo último en razón a que las operaciones militares contra los rebeldes no han sido suspendidas, ya que no hay un cese al fuego bilateral; también debido al sigilo al que están sometidos los temas materia de acuerdo, lo que impide hacer proselitismo político con ellos.

En el siglo XX la guerrilla, autodefensas paramilitares y narcotráfico, tienen la doble condición de ser causa de la hoguera de violencia que ha incendiado al país durante los últimos 35 años, pero también son consecuencia de procesos previos de ausencia de Estado y deterioro social. Gracias a los recursos del narcotráfico, hoy, ya no se tratan de pequeños grupos armados, sino de verdaderos ejércitos privados con unidad de mando y descentralización regional, con comunicaciones modernas, alta capacidad de fuego e intenso control político en sus zonas de influencia. Uno de los factores que profundizó la crisis de valores, la erosión de las instituciones y la prolongación del conflicto armado fue la economía de las drogas ilícitas. El tráfico de drogas 
no solo garantizó los recursos para financiar la actividad insurgente y contrainsurgente, sino que permeo amplios sectores de la sociedad dejando una escala inconmensurable de corrupción, magnicidios e impunidad.

Para los años 80 las bandas colombianas, tomadas en conjunto, se convirtieron en el primer productor mundial de cocaína. En ese escenario, se conjuraron los más diversos intereses en un juego sucio de promiscuidad entre guerrillas, autodefensas, bandas de la droga y delincuencia común. Esto, pues formaron alianzas para proteger sus cocinas en plena selva y mantener despejados los corredores estratégicos para la comercialización de los estupefacientes. Igualmente, se formaron grupos para la delincuencia común, la práctica del secuestro y de la extorsión, la compra de jueces y hasta votos en las campañas electorales. De suerte que la institucionalidad y la civilidad se ven destruidas.

Los grupos paramilitares, que llegaron a tener un piso de legalidad durante La Violencia, y luego con la legislación producida en el Gobierno de Guillermo León Valencia, se vieron alentados con los grupos de seguridad o las "Compartir" autorizadas durante el gobierno de Ernesto Samper. Los paramilitares han sido activos en las infracciones al DIH. Tuvieron un papel muy activo en el tráfico de drogas. Desmovilizados en su mayoría durante el gobierno de Álvaro Uribe Vélez, en todo caso, degeneraron en múltiples bandas dedicadas al sicariato, la extorsión y el narcotráfico.

Las FARC-EP han buscado la participación en todas las etapas productivas del negocio de las drogas, su intervención comprende la producción, cultivo y comercialización de la hoja de 
coca, cocaína y heroína, construcción y protección de pistas de aterrizaje, laboratorios, cristalizaderos propios, así como el cobro del llamado impuesto del "gramaje" sobre la negociación de base de coca. Alterno al negocio de las drogas ilícitas florecieron negocios como el tráfico de armas, municiones y explosivos y todo lo relacionado con los insumos de procesamiento y transporte de drogas ${ }^{114}$. En consecuencia, el tema del narcotráfico debe ser parte esencial de cualquier programa de políticas públicas en seguridad.

En el trasfondo de la problemática de violencia en Colombia, siempre ha permanecido latente la cuestión de la usurpación de las tierras. La violencia ha sido históricamente utilizada, desde el siglo XIX, para despojar a otros de sus tierras. Por ende, una política de seguridad con la potencialidad para ser eficaz debe tener presente la cuestión de la propiedad de la tierra.

2.- Políticas Públicas en Seguridad y Funciones Sociales.-

Las políticas públicas comprenden numerosos campos en el ámbito de lo público susceptibles de regulación, intervención y dirección por medio de acciones ejecutadas por el Estado. Los grupos sociales organizados participan en la concepción y ejecución de políticas, ya sea acompañando a las agencias del Estado o de manera autónoma. Sin embargo, las políticas públicas son patrimonio exclusivo de las autoridades estatales, pese a que pueden estar sujetas a

${ }^{114}$ José Félix Lafáurie Rivera. Posconflicto y Desarrollo, Bogotá, FEDEGAN, 2006, p. 495. 
la influencia, en distintos grados, de agentes privados ${ }^{115}$. Por tanto, los particulares pueden ser actores de políticas de seguridad, como en efecto lo han sido en Colombia, pero solamente el Estado es el protagonista de las políticas públicas en seguridad. Este texto se ocupará no de la políticas de seguridad, sino de las políticas públicas de seguridad, de manera particular las trazadas y llevadas a cabo en los últimos años.

En un sentido considerablemente amplio, la seguridad es un mecanismo que es invocado respecto de todos los ámbitos de la sociedad que pueden encontrarse bajo peligro o amenaza, y que el Estado debe proteger. La anterior noción de seguridad abarca muy disimiles campos. Con todo, en el contexto de este trabajo interesa la seguridad política, en el sentido de preservación de la paz, la institucionalidad del Estado y la estabilidad de la sociedad, mediante el concurso de la defensa o la seguridad nacionales, frente a factores de perturbación externos o internos. Ya de modo más restringido, en este trabajo importa únicamente la seguridad política interna.

La seguridad política, tiene entonces relación con la preservación del Estado y la sociedad. Cuando se trata de la seguridad política interna, ella puede verse afectada, de manera preponderante, aunque no única, por las consecuencias que acarrea un conflicto armado interno. En consecuencia, la naturaleza de las amenazas referidas a la seguridad política interna son muy distintas de las que pueden comparecer cuando se aborda la seguridad externa y, en la misma proporción, con toda probabilidad las características y atributos de la política pública en seguridad son diversas cuando se trata, según el caso, de amenazas internas o externas.

\footnotetext{
${ }^{115}$ Se entiende por política pública el "proceso integrador de decisiones, acciones, inacciones, acuerdos e instrumentos, adelantado por autoridades públicas con la participación eventual de los particulares, y encaminado a solucionar o prevenir una situación definida como problemática", Raúl Velásquez Gavilanes. "Hacia una nueva definición del concepto de 'política pública', en Desafíos, No. 20, Bogotá, 2009, p. 156.
} 
Se ha dicho antes que, con bastante frecuencia, los problemas de inseguridad y violencia han buscado contrarrestarse no sólo con el concurso de una política pública en materia de seguridad política, sino además por medio de la política penal, que muchos otros llaman política criminal. Esto significa una utilización privilegiada del Derecho penal y de las agencias de control social penal orientadas de manera principal a enfrentar y reducir la criminalidad. En ese sentido, debe tenerse en cuenta que la política penal "es el programa de acción para tratar la divergencia de interés penal y conducir el control penal, lo que comprende como medios el conjunto de concepciones, medidas y prácticas penales diseñadas y ejecutadas por el Estado o por grupos sociales organizados, en un tiempo y espacio determinados, para materializar objetivos o intereses superiores de la organización social respectiva." ${ }^{116}$

No toda modalidad delictiva es objeto de interés para las políticas se seguridad, puesto que no todas las formas de criminalidad pueden llegar a tener la suficiente envergadura como para amenazar o lesionar la paz, la institucionalidad estatal o la estabilidad social, ni requieren de la movilización de la defensa nacional. En cambio, todas las manifestaciones de divergencia social que llegan a considerarse de interés penal incumben a las políticas penales. En medio de uno y otro campo, se encuentran varias materias que pueden involucrar tanto la atención de las políticas de seguridad como de las políticas penales, como las sublevaciones políticas, el accionar de grandes bandas de narcotraficantes, las actividades de grupos delincuenciales como las llamadas "BACRIM". Las organizaciones ilegales y las actuaciones que llevan a cabo relacionadas con las materias que se acaban de indicar constituyen una zona común a las intervenciones de las políticas de seguridad y de las penales, sin que exista claridad ninguna

${ }^{116}$ Silva García. Criminología. Teoría, cit., p. 45. 
sobre lo que corresponde a cada una de las dos políticas. De hecho, las políticas de seguridad adoptan muchos dispositivos que pertenecen al ámbito de las políticas penales.

A continuación, en los análisis subsiguientes, se hará alusión a las políticas de seguridad, sin distinguir especialmente entre políticas de seguridad y políticas penales, salvo que concurra alguna novedad que lo haga forzoso. Así mismo, excepto que se requiera algún tipo de precisión singular (como en el caso de la Doctrina de Seguridad Nacional que en seguida será examinado), se estará tratando acerca de la seguridad política interna.

Desde un punto de vista histórico, conviene resaltar que durante buena parte del siglo XX en América Latina, sin que Colombia fuera una excepción, imperó en el campo la denominada Doctrina de la Seguridad Nacional. Joseph Comblin, un sacerdote y sociólogo francés, expuso las cualidades principales de dicha doctrina, la cual había sido impuesta por Estados Unidos en todo el continente. La Doctrina de la Seguridad Nacional fue un producto derivado de la Guerra Fría que tuvo comienzo luego de la Segunda Guerra Mundial, la cual enfrentaba a Estados Unidos y sus aliados en Occidente contra la Unión Soviética y los países que hacían parte del bloque socialista o de la llamada "Cortina de Hierro". Conforme a la Doctrina se consideraba que existía una amenaza externa o foránea, identificada como el peligro de invasión comunista, que actuaba en cada país por medio de infiltrados en organizaciones sociales y políticas, los cuales debían ser considerados como enemigos extranjeros. El mundo Occidental y cristiano era blanco de un ataque por parte de países de Oriente ateos, inspirados en una ideología foránea representada en el comunismo. Lo cual demandaba del desarrollo de acciones de defensa nacional con el fin de extirpar a esos enemigos, que como tales no tenían derechos ciudadanos. 
Al tratarse de enemigos externos, de un plan de invasión contra los países latinoamericanos, que buscaba hacerse al poder desde adentro por medio de la subversión política, armado o no, sin importar que concurriera bajo una apariencia de legalidad, demandaba activar la defensa militar, como pivote principal de la defensa nacional. En consecuencia, las Fuerzas Militares eran convocadas como protagonistas centrales para dirigir y ejecutar la Doctrina de la Seguridad Nacional. Esencialmente, podía señalarse que la Doctrina de la Seguridad Nacional pretendía preservar indemne la unidad del Estado, defender la soberanía nacional supuestamente amenazada por fuerzas foráneas, la integridad del territorio, garantizar la convivencia pacífica y el orden público, así como la paz social ${ }^{117}$.

A partir de 1990, después de la caída del Muro de Berlín en 1989, y definitivamente con el derrumbe de la Unión Soviética, los viejos conceptos de la Doctrina de la Seguridad Nacional se hicieron obsoletos. Esto produjo una descolocación entre los miembros de las agencias de seguridad y de las Fuerzas Armadas de América Latina aún apegados a la vieja Doctrina, que no encontraban un norte que definieran de manera estratégica la orientación de las acciones de control. Empero, particularmente, luego de los atentados del 11 de septiembre de 2001, bajo la inspiración del Gobierno de Estados Unidos, el mundo Occidental fue testigo del nacimiento de un nuevo paradigma de la seguridad, el cual identificaba al terrorismo como el blanco novedoso de las acciones de defensa y seguridad nacionales.

117 Ana María Salazar. Seguridad Nacional Hoy: el reto de las democracias, México D.F., Punto de Lectura, 2008, pp. 70 y 71. 
También, el terrorismo serviría al propósito de justificar nuevos órdenes jurídicos, lo mismo que una política internacional de intervención en otros países justificada en la necesidad de combatirlo, al lado de una globalización de control dado que se consideraba que el terrorismo debía comprometer los esfuerzos internacionales visto que éste no tenía una nacionalidad específica, y circulaba por todo el mundo sin que las fronteras pudieran detenerlo. Sobre el contexto anterior, emergió la Política de Seguridad Democrática del Gobierno del presidente Álvaro Uribe Vélez, que fijó en la derrota de la amenaza terrorista el propósito de su política, con lo cual de manera conveniente logró insertar su política como una pieza del concierto internacional que luchaba contra el terrorismo.

La política de seguridad es un medio para la realización del control social. El control social es "el conjunto de instituciones, dispositivos y prácticas destinadas a preservar o imponer un determinado orden para regular las relaciones sociales" ${ }^{\text {"118 }}$. Ese orden al que se alude no es otro que el previsto en la Constitución Política y debe corresponder a la figura del Estado social de derecho adoptado por la Carta política. Sus rasgos y características distintivas fueron señaladas en el capítulo primero de este trabajo. Ahora bien, sin duda las definiciones específicas y, sobre todo, las prácticas de las políticas de seguridad adoptadas después de la Constitución de 1991 han generado una situación de tensión con el modelo constitucional de Estado. Sin embargo, ese modelo, se repite, expuesto en el capítulo primero de este texto, debe ser el referente al momento de analizar las políticas de seguridad ${ }^{119}$.

\footnotetext{
${ }_{118}^{118}$ Silva García. Criminología. Teoría, cit., p. 138.

119 La jurisprudencia ha establecido los alcances de las políticas de seguridad, dentro del objetivo de compaginarlas con los derechos fundamentales. Al respecto, Corte Constitucional, Sentencia T-525 de 1992, magistrado ponente Ciro Angarita Barón.
} 
De conformidad con el referente antes indicado, los derechos fundamentales deben constituir el marco principal de regulación y de orientación de las políticas de seguridad. Como marco de orientación, la realización de los derechos fundamentales debe ser el propósito superior de las políticas de seguridad. Como marco de regulación, los derechos fundamentales son el límite que establece los mojones o hitos dentro de los cuales deben ser aplicadas las medidas de la política de seguridad, lo que significa que no debe exceder esos linderos.

De acuerdo con lo señalado, las políticas de seguridad no constituyen un objetivo, sino un medio para la realización de los derechos fundamentales, que representan la meta política superior de la organización social, es decir, que condensan los objetivos nacionales. Lo anterior, en términos de deber ser, es decir, se trata de un fin, respecto del cual es necesario ser conscientes que tiene un valor relativo, ya que ningún Estado puede ufanarse de obtener un nivel óptimo de seguridad. La noción de políticas de seguridad es dinámica y flexible, dado que enfrenta fenómenos cambiantes, a su vez, dotados de altos niveles de flexibilidad o variación de conformidad con las condiciones sociales, culturales, políticas y económicas de una nación en sus distintos momentos históricos. Hoy por hoy, las políticas de seguridad están intensamente afectadas por procesos de globalización, que superan los ámbitos puramente locales, lo que supone que existen organismos internacionales y países extranjeros que inciden y, a veces, determinan, el curso de las políticas de seguridad, como también es claro que los fenómenos de violencia e inseguridad obedecen también a variables de internacionalización. Las políticas de seguridad deben, en tanto correspondan a políticas públicas, ser patrimonio exclusivo del Estado, lo que no obsta para que puedan estar abiertas a procesos de participación ciudadana. Finalmente, el Estado social de derecho adoptado en Colombia es también un Estado 
participativo. Sin embargo, los actores y los procesos de participación deben ser del todo transparentes, a fin de evitar que las políticas públicas en seguridad se conviertan en un instrumento de intereses privados, ajenos al interés público.

Se deduce que la seguridad nacional debe ser un concepto indivisible a fin de asegurar la consecución de sus objetivos nacionales, lo que no obsta para ignorar que las políticas de control social, lo que comprende también, pues es una parte de ellas, a las políticas de seguridad, están profundamente fragmentadas. Esto tiene una directa relación con la fragmentación del poder político del Estado, entre distintos actores sociales y políticos, lo que representa una situación indeseable, pero también una realidad incontestable.

Las amenazas o atentados contra la seguridad, reflejados en acciones que provoquen un daño o tengan la capacidad para alterar de modo grave la paz pública, la institucionalidad definida en la Constitución y la estabilidad de la sociedad constituye el antagonismo que debe ser enfrentado mediante las políticas de seguridad. Tales amenazas a la seguridad implican la germinación de un proceso subversivo, que adopta una línea de violencia impulsada por diversas ideologías y por crisis de carácter socioeconómico que las nutren ${ }^{120}$.

Con todo, más allá de la anterior concepción general, es cada Gobierno el que desarrolla, primero, el diagnóstico sobre la tipología de problemática que habrá de enfrentar, sus rasgos y característica y, segundo, en concordancia con lo anterior, la política pública en materia de

\footnotetext{
120 Jorge Enrique Ibáñez Najar. Seguridad Nacional, seguridad del Estado y seguridad ciudadana: una aproximación jurídica, Bogotá, Universidad Sergio Arboleda, 2005, p. 53 a 57.
} 
seguridad que va a adoptar, sus objetivos, al igual que los indicadores y evidencia que deben ser contemplados a efectos de sopesar los resultados de la aplicación de sus medidas y acciones.

El Gobierno del presidente Álvaro Uribe Vélez definió y adoptó una clase de política como modelo, la que denominó Política de Seguridad Democrática. Sus propósitos generales tenían que ver con garantizar el amparo eficaz de los derechos de la población, junto al fortalecimiento de la solidaridad de la ciudadanía con el Estado de Derecho y la autoridad democrática frente a cualquier vulneración o amenaza. Esto suponía, por una parte, generar nuevas actitudes entre la población, lo que sólo podría alcanzarse si se reestablecía la confianza de los ciudadanos en las autoridades y, por otra parte, un afianzamiento sólido de la autoridad democrática, la soberanía democrática y la capacidad del Estado de hacer prevalecer el orden jurídico para toda la población.

Sobre las bases anteriores, la Política de Seguridad Democrática pretendía abrazar tres principios: 1. Protección de los derechos de todos los ciudadanos, en concordancia con el deber constitucional de defender la vida, honra y bienes de los asociados; 2. Protección de los valores e instituciones democráticas, lo que ha de traducirse en una defensa de las expresiones políticas democráticas previstas en la Constitución, ejercidas de manera directa por los ciudadanos o por sus representantes, sean opositores o afines al Gobierno; 3 . Solidaridad y cooperación de la ciudadanía en defensa de los valores e instituciones democráticas, lo que envuelve una exigencia de cumplimiento por parte de los ciudadanos de sus obligaciones y deberes constitucionales. De tal modo, la Política de Seguridad Democrática planteaba: 
I. El Gobierno trabajará en la consolidación del control estatal del territorio garantizando la presencia de la Fuerza Pública en todos los municipios, con la imputación penal de delitos de alto impacto social, ampliando y fortaleciendo la administración de justicia, el aparato estatal, y mitigando la violación de los derechos humanos.

II. Protegerá a la población a través de la disminución del secuestro, la extorsión, el homicidio, evitando el desplazamiento forzado y permitiendo la devolución de sus tierras a los desplazados, facilitando la reinserción a la vida civil de los individuos que conformen grupos al margen de la ley y la desintegración de las organizaciones terroristas.

III. Asumirá la eliminación del comercio de las drogas ilícitas erradicando los cultivos de amapola y de coca, la prohibición del tráfico de drogas por vía marítima, terrestre, fluvial y aérea, el combatimiento de las redes de narcotraficantes, la posesión por parte del Gobierno de las propiedades del narcotráfico.

IV. Buscará el mantenimiento de la capacidad disuasiva por medio de la defensa de las fronteras terrestres, marítimas y fluviales.

En este sentido el Gobierno del presidente Uribe Vélez consignó seis líneas de acción para la realización de las finalidades estratégicas definidas en su política, consistentes en: 1. Coordinación de las acciones del Estado, con la intervención directa del propio presidente de la República y del Consejo de Seguridad y Defensa Nacional, a efectos de asignar competencias, establecer responsabilidades y misiones específicas, lo mismo que para definir los mecanismos e 
instancias de supervisión de las tareas desarrolladas y los resultados alcanzados. 2. Fortalecer las instituciones del Estado y del sistema judicial, lo que suponía avanzar en la capacitación de los miembros de las Fuerzas Armadas, mejorar los sistemas de inteligencia y mejorar el armamento a disposición de las Fuerzas, lo mismo que la introducción de reformas a la justicia, particularmente a la penal, para que ella fuera pronta y eficaz; 3. Consolidar el control de todo el territorio nacional, mediante una presencia permanente y eficaz de las Fuerzas Armadas en todos los municipios del país y en las fronteras, al lado de las demás instituciones del Estado como la administración de justicia; 4. Proteger la integridad de los ciudadanos y la infraestructura, con el concurso de programas especiales de protección de personas y de la infraestructura vial y productiva de la nación; 5. Desarrollo de programas de cooperación, a fin de asegurar la participación ciudadana y el trabajo estrecho de ella con las autoridades; 6. Comunicar las políticas y acciones del Estado ${ }^{121}$.

El Gobierno del presidente Álvaro Uribe Vélez adelantó un proceso de acuerdos para conseguir la desmovilización de grupos paramilitares. Ese proceso de negociaciones y sus acuerdos hacen parte de la política de seguridad del gobierno, en la medida en que apuntaban a lograr la neutralización de actores armados y, en consecuencia, debe ser evaluado como componente de la Política de Seguridad Democrática.

En cuanto a los objetivos postulados por la Política de Seguridad Democrática que fueron expuestos antes, en lo que concierne al primero de ellos, relativo a la "la consolidación del control estatal del territorio", que corresponde también al tercer lineamiento de dicha política de

${ }^{121}$ La Política de Seguridad Democrática aparece consignada en el documento "Manifiesto Democrático" de 2002. 
seguridad, el Gobierno puso en práctica acciones como la creación de batallones de alta montaña que interceptaron las rutas de comunicación de la guerrilla. Esto se combinó con la creación de bases en algunas regiones estratégicas como la del Sumapaz. De este modo no sólo se obtuvo presencia territorial, sino aún más importante, se cortaron u obstaculizaron seriamente las comunicaciones terrestres de la guerrilla, lo que afectó un aspecto estratégico clave de la guerra interna. Así mismo, se organizaron batallones de soldados campesinos, en los que los soldados iban a permanecer en sus mismas zonas de origen, lo que aumento la presencia militar en los territorios, pero además se buscó granjearse el apoyo irrestricto de la población de esas zonas al Ejército. La policía retorno a municipios donde se había visto obligada a retirarse por los continuos ataques de la guerrilla y, a la vez, se construyeron cuarteles de policía para lograr un cubrimiento territorial del $100 \%$ en los municipios del país. De este modo la política de seguridad cumplió una función social manifiesta de aseguramiento sustancial, pero desde luego relativo, puesto que esto nunca podría alcanzarse en términos absolutos, del control territorial.

Sobre la segunda finalidad de la Política de Seguridad atinente a la protección de la “población a través de la disminución del secuestro" y otros delitos, los resultados fueron dispares. Ciertamente se obtuvo una disminución notable del secuestro y la extorsión, en lo que el cese de las llamadas "pescas milagrosas" o secuestros masivos derivado del control de las carreteras fue importante ${ }^{122}$. Sin embargo, los resultados en otras modalidades de divergencia social reputadas como delictivas, como en el homicidio y en el narcotráfico, al igual que en el desplazamiento, pese a que en ocasiones se cambiaron los parámetros de medición para buscar mejores resultados estadísticos (como en el homicidio), el éxito fue bastante relativo.

\footnotetext{
${ }^{122}$ Al respecto, los datos del Centro Nacional de Memoria Histórica. ¡Basta ya! Colombia: memorias de guerra y dignidad, Bogotá, Centro Nacional de Memoria Histórica y República de Colombia DPS, 2013, pp. 64 y ss.
} 
La meta de eliminación del tráfico de drogas ilícitas no fue llevada a cabo. En cambio, se conoce que el proceso de desmovilización y entrega de los paramilitares fue utilizado como mampara para legalizar la situación de varios traficantes de drogas, que no tenían que ver con la lucha antisubversiva que se planteaban las autodefensas de las AUC y otros grupos análogos. De esta manera, en forma parcial, el proceso de negociación con los paramilitares, como parte de la Política de Seguridad Democrática cumplió con la función social latente de servir para la consecución de un estado de impunidad a favor de narcotraficantes.

En lo referente a la segunda línea, que sostenía el plan de "Fortalecer las instituciones del Estado y del sistema judicial", lo mismo que las Fuerzas Armadas, es necesario escindir los dos temas. Las Fuerzas Armadas fueron fortalecidas, lo que en realidad venía sucediendo de modo notable desde el Gobierno del presidente Andrés Pastrana Arango, con el concurso del Plan Colombia y la intervención de Estados Unidos. Empero, aquí se trata de un medio, necesario para el logro de los objetivos de la política de seguridad, el cual se cumplió, y por esa vía se contribuyó a la verificación de funciones manifiestas conectadas a los fines esenciales de la Política en materia, precisamente, de seguridad.

La situación es distinta con relación a la justicia. La reforma a la justicia que el Gobierno de Uribe Vélez proyectó, pero finalmente decidió no someter al Congreso, no buscaba la mejora de la administración de justicia, sino asegurar el control político sobre la justicia. Las denuncias sobre interceptaciones y espionaje a la Corte Suprema de Justicia por parte de agencias del Gobierno, ilustra el nulo marco democrático de las relaciones entre el poder ejecutivo y el 
judicial. El aumento generalizado de penas no cumplió ningún papel disuasivo, poniendo en evidencia la pobreza y falta de creatividad de la política penal. La profundización del sistema penal de tendencia acusatoria, dada la crisis generalizada en la que se encuentra, es expresión irrebatible del fracaso de las políticas penales y de sus resultados en la generación de un grave estado de impunidad. En cambio, se dio continuidad a un conjunto de vicios y malas prácticas históricas, que apuntan a la deformación y distorsión de las funciones jurisdiccionales y del papel del derecho penal en la sociedad, en unos términos que además no son compatibles con el estado social de derecho.

En el último sentido, es bastante contundente el informe del grupo de Nacional de Memoria Histórica, cuando afirma: "Nuestra justicia, y en particular nuestra justicia penal, como se expone en el capítulo 3, es incomprensible sin la guerra, pues la primera, a pesar de su relativa independencia y credibilidad entre las instituciones del Estado, ha sido parcialmente configurada tanto por cuenta de actores armados específicos que en determinados momentos han optado por vincular el sistema de justicia a sus estrategias armadas — por la vía de la captura, la instrumentalización, la victimización o la limitación violenta de su funcionamiento—o por cuenta de la dinámica compleja del conflicto armado colombiano, que indujo la creación de diseños institucionales, algunos perversos, para enfrentar lo que en cada momento fue considerado como la más grave amenaza." Problemas que en los últimos años se han agravado, dada la pérdida creciente de independencia de la administración de justicia y de politización de la misma. 
Por ello el diagnóstico del Centro Nacional de Memoria Histórica agrega: "Señala con particular énfasis los terribles costos que para la democracia significó la legalización de formas de justicia privada, la instrumentalización del sistema judicial con fines bélicos y la injerencia de organismos militares tanto en procesos judiciales adelantados contra civiles como en el juzgamiento de graves violaciones presuntamente cometidas por miembros de la Fuerza Pública." 123

De conformidad con lo anterior, las intervenciones en el campo judicial y penal, anejas a la Política de seguridad democrática, cumplieron la función social latente de contribuir a la perversión de las instituciones judiciales y penales.

En el desarrollo de la Política de Seguridad Democrática, especialmente en los primeros años que corresponden a la primera de las administraciones del presidente Uribe Vélez, esto es durante el 2003 y el 2004, se adelantó un plan de capturas masivas de civiles, acusados de hacer parte integrante de organizaciones guerrilleras. A partir del 2004 hasta el 2006, el plan fue ajustado para transformarlo en una campaña de detenciones selectivas, dirigidas sobre todo a integrantes y activistas de los movimientos y organizaciones sociales. La inmensa mayoría de los detenidos fueron luego puestos en libertad ante la carencia de pruebas ${ }^{124}$.

En este evento los fines de la Política de Seguridad no se materializaron, habida cuenta que los capturados no fueron procesados y condenados. En cambio, la campaña de capturas,

${ }^{123}$ Centro Nacional de Memoria Histórica. ;Basta ya! Colombia, cit., p. 23.

${ }^{124}$ Sobre la afectación generalizada del derecho a la libertad, que significó en 2002 un total de 2.972 detenidos, en 2003 una cifra de 2.598 detenciones, en 2004 una suma de 927, en 2005 una cantidad de 371 y para 2006 un total de 266 detenidos, con una alta afectación de la población de los departamento de Arauca y Antioquia, Carvajal Martínez. La seguridad, cit., pp. 110 a 112. 
tanto la indiscriminada como la selectiva, cumplieron la función social latente de afectar injustificadamente el derecho fundamental a la libertad, lo mismo que el derecho fundamental a la presunción de inocencia, en tanto las Fuerzas de seguridad obraban basados en sospechas y perjuicios, no con base en evidencias.

Otro de los problemas, indirectamente relacionado con la salvaguarda de los derechos fundamentales de la población, era el relativo a la protección de los defensores de los derechos humanos, puesto que ellos desempeñan un rol esencial en la promoción y defensa de esos derechos, por lo que su amparo eficiente debía ser considerado un requisito clave para consolidar una política de seguridad acorde con el Estado social de derecho.

Empero, durante el Gobierno de Uribe Vélez se incrementaron de modo notable los ataques en los discursos oficiales contra los defensores de derechos humanos, que constantemente eran catalogados como agentes solapados de los grupos subversivos. Las acciones del Estado, que no tenían efecto alguno respecto de los fines postulados por la Política de Seguridad Democrática, ni eran idóneas a efectos de alcanzarlos, cumplieron la función social de desprestigiar y deslegitimar la labor de los defensores de derechos humanos. Si a ello se suma un incremento considerable de los asesinatos dirigidos contra defensores de derechos humanos, como resultado combinado de los dos hechos comentados, se tiene que: el activismo en pro de los derechos humanos se volvió peligroso, mientras que la estigmatización de la promoción de los derechos humanos redujo los márgenes de maniobra del trabajo de los defensores. De allí, que pueda concluirse que una función social latente de la política de Estado, aunada a la 
actuación ilegal de los perseguidores que cegaban la vida de los defensores, consistió en una reducción notoria de las labores de protección de los derechos humanos en el país.

Durante la segunda administración del presidente Uribe Vélez, especialmente, se produjeron una serie de ejecuciones extrajudiciales, valga decir asesinatos, de personas a las que las autoridades militares hicieron pasar por guerrilleros dados de baja, los que fueron conocidos con el mote de "falsos positivos". Aunque no puede decirse que tales homicidios respondían a una política de Estado, pese a que muchas veces fueron consentidos, tolerados o animados por oficiales con mando superior sobre las tropas, esta situación tiene una inocultable relación con los estímulos con los que se premiaban o reconocían las acciones militares y, por otra parte, con el control sobre la eficiencia operativa de las Fuerzas Armadas que de manera intensa era ejercido por el mando militar e, inclusive, por el propio presidente Uribe Vélez que lo ejecutaba de manera personal y directa. En otras palabras, las consecuencias sociales verificadas tienen una relación directa con el primero de los lineamientos antes expuestos para la Política de Seguridad Democrática. La gravedad de los hechos anteriores en términos cualitativos es patente, puesto que afectaba el derecho fundamental a la vida; mientras que en un plano cuantitativo la gravedad también era mayúscula, puesto que más de tres mil militares están siendo o han sido investigados y procesados por los falsos positivos.

En este caso, la Política de Seguridad Democrática cumplió con varias funciones sociales latentes. Entre ellas se cuenta la de haber impulsado o propiciado una lesión relevante al derecho fundamental a la vida; igualmente, la de haber provocado una banalización del derecho fundamental a la vida, con una pérdida evidente de los más elementales referentes éticos. Lo 
anterior, puesto que los premios o reconocimientos que obtenían los militares que reclamaban los supuestos éxitos militares eran, en realidad, absolutamente banales en comparación con el derecho fundamental que destruían, ya que se trataba de ventajas tales como la obtención de un permiso de trabajo por un fin de semana. Se agrega la función de haber generado una deslegitimación de las Fuerzas Armadas, un elemento clave, al tenor de la misma Política de Seguridad Democrática, pues del mismo depende la cooperación de la población civil.

Aun cuando uno de los aspectos fundamentales del legado político que había dejado el presidente Álvaro Uribe Vélez era su Política de Seguridad Democrática, que públicamente había sido aceptado por su sucesor, el presidente Juan Manuel Santos, quien así se comprometía a darle continuidad, en la práctica se planteó una nueva política, la cual, sin duda, conservaba no pocos aspectos de la anterior, pero también era dueña de sus propios matices. La misma fue llamada Política Integral de Seguridad y Defensa para la Prosperidad, la cual fue perfilada por el presidente Santos en asocio con el Ministerio de Defensa.

La Política Integral de Seguridad y Defensa para la Prosperidad tenía como objetivos: 1. La disminución del impacto del tráfico ilícito de drogas, lo que marchaba asociado a la eliminación de las BACRIM; 2. La desarticulación de las organizaciones armadas ilegales; 3. La provisión de seguridad a todo el territorio nacional con el fin de facilitar el desarrollo de relaciones de convivencias, lo que implica reducir los índices de criminalidad en todos los campos; 4. Desarrollar acciones que puedan ser eficaces para disuadir las amenazas de transgresión a la ley; 5. Disponer de planes para la atención de desastres y emergencias 
humanitarias; 6. Proveer mejoras en el sistema de seguridad social y jurídica, lo mismo que el bienestar del sector defensa.

El primero de los objetivos antes citados no se ha realizado en modo alguno.

Probablemente la única fórmula eficiente, planteada por el presidente Santos, pero de difícil materialización sería la legalización de las drogas. El segundo objetivo no se ha cumplido, aunque se han propinado golpes importantes a altos dirigentes de las FARC-EP y existirían posibilidades de lograr esa desarticulación, pero a través de las negociaciones de paz. El cuarto objetivo tampoco se ha cumplido, pese a que la estrategia preferida de las reformas penales ha sido la de incrementar las penas, lo que no produce los efectos deseados de desanimar el delito. En este terreno, así mismo, la reforma a la justicia postulada por el Gobierno Santos terminó en una debacle, sin contar que la misma era inoficiosa desde el punto de vista de la meta de mejorar el funcionamiento de la justicia. El quinto objetivo se verificó, al menos en los que significó la atención eficiente de los desastres ocasionados por la ola invernal. El sexto objetivo no puede decirse que haya sido logrado a satisfacción: la reforma a la justicia penal militar fue declarada inconstitucional, el pasivo pensional de los servidores de las Fuerzas Armadas expone un fututo oscuro y preocupante para la estabilidad de las finanzas públicas, pero en todo caso de manera tradicional los integrantes de las Fuerzas Armadas gozan de un número considerable de prebendas especiales. El funcionamiento del sistema de defensa jurídica de los integrantes de las Fuerzas Armadas, que en todo caso es una privada ha tenido escándalos y no tiene una imagen significativa de eficiencia. 
Así mismo, la Política Integral de Seguridad y Defensa para la Prosperidad ha definido un conjunto de tareas estratégicas, como parte de su estructura, lo que comprende: A. Perfeccionamiento de los servicios de inteligencia y de su capacidad operacional; B. Fortalecimiento del mando militar y de las funciones de control derivadas del mismo; C. Incremento de los niveles de coordinación entre las Armas y entre las distintas unidades de cada Fuerza; D. Defensa de la población civil; E. Incremento de la capacidad operativa para neutralizar los grupos al margen y las BACRIM; F. Respeto incondicional de la ley, de los derechos humanos, el DIH y la ética. ${ }^{125}$

Aunque no fue inicialmente previsto al comenzar el Gobierno del presidente Juan Manuel Santos y, desde luego el tema no hizo parte específica y directa de sus propuestas de gobierno cuando se desarrollaba la campaña presidencial, las negociaciones de paz adelantadas con las FARC-EP, sin duda, hacen parte integrante de la política de seguridad del Gobierno Santos. Dichas negociaciones no contradicen las estrategias, principios y plan de acciones de la Política Integral de Seguridad y Defensa para la Prosperidad, sino que se integran perfectamente con sus enunciados. A ello se suma el inicio, desde enero de 2014, de las conversaciones con el ELN para definir los términos y condiciones de una negociación, que también harían parte de la política de seguridad gubernamental.

Parte de la estrategia de seguridad del Gobierno del presidente Juan Manuel Santos apunta a la atención y reparación de las víctimas del conflicto. Esto marcó un giro radical respecto del Gobierno anterior, que en modo alguno se preocupó por la reivindicación y la

125 Documento "Libertad y Orden", consultado en marzo de 2014 en la página Web www.mindefensa.gov.co. 
reparación a la población civil víctima de la conflagración. La Unidad para las Víctimas ha manejado un total de 2.128.045 solicitudes de atención humanitaria de emergencia, a lo que se suma el pago de indemnizaciones a 253.316 víctimas de hechos diferentes al desplazamiento armado. Sin embargo, la enorme cantidad de víctimas del conflicto armado interno durante los últimos años, pese a los esfuerzos, permanece sin atención por el programa. Sólo en materia de desplazamiento interno las víctimas ascienden a 5.5 millones de personas, desde 1985, de acuerdo con la oficina gubernamental de Unidad de Víctimas. Ciertamente, la indemnización de todas las víctimas, además de una manera que resulte eficaz y satisfactoria bajo cánones de equidad y justicia, es financieramente un reto casi imposible.

La Política Integral de Seguridad y Defensa para la Prosperidad ha cumplido con la función social simbólica de proveer la apariencia de que las víctimas del conflicto armado interno son reparadas, aun cuando los esfuerzos en la materia están lejos de una materialización efectiva, acorde con los fines trazados por la política gubernamental. Dicha función social es importante, puesto que le resta presión política a la ejecución de las políticas de seguridad que, así, tal vez pueda realizar de modo más eficiente y real otras de sus metas.

La Política Integral de Seguridad y Defensa para la Prosperidad se ha ocupado de la problemática del despojo y de la restitución de tierras. Al igual que en el caso anterior, esto también representa un giro trascendental respecto de la política de seguridad del Gobierno de Uribe Vélez, que se opuso de manera sospechosa e injustificable a la Ley de restitución de tierras. Como se recordará, páginas atrás se indicó que el tema constituía la cuestión central de los fenómenos recurrentes de violencia y conflictividad en la historia del país, desde el siglo 
XIX $^{126}$. La ley 1448 de 2011 es el instrumento jurídico principal de los programas de restitución de tierras. Dicha Ley creó la Unidad Administrativa Especial de Gestión de Tierras Despojadas, que posee oficinas descentralizadas en todo el país. Hasta 2014 se habían recibido 41.830 peticiones para el Registro de Tierras Despojadas y Abandonadas Forzosamente, lo que corresponde a 2.8 millones de hectáreas, a la par que se inician los procesos judiciales que deben desembocar el efectivo decreto de las restituciones. Con todo, ha sido frecuente el asesinato impune de líderes campesinos que encabezan las acciones de restitución, además de las amenazas a muchos más. La infiltración de agentes de narcotraficantes, exmiembros de grupos paramilitares y de BACRIM en agencias del Estado relacionadas con la restitución, denunciadas de manera profusa, constituye otra amenaza real al proceso.

Todavía es prematuro emitir un juicio sobre los resultados de la política de seguridad en sede de restitución de tierras. La no protección efectiva de los dirigentes campesinos involucrados en el proceso, y la impunidad que reina sobre los asesinatos cometidos es una señal de alarma sobre el futuro de la política. En verdad, este es un punto donde el Estado no debería ahorrar ni recursos ni medios. No obstante, puede acotarse que la política ha cumplido la función social manifiesta de transmitir la idea de un compromiso del Estado con la restitución.

Las negociaciones de paz con las FARC-EP se encuentran en curso. Por ende, es imposible valorar las consecuencias sociales de un eventual acuerdo. Sin embargo, la manera como fueron estructuradas las conversaciones de paz tenían la finalidad de evitar que el movimiento guerrillero, como había ocurrido en procesos previos, pudiera obtener ventajas militares y políticas de la negociación. Esta finalidad descansaba sobre varios elementos de las condiciones de negociación: 1. Obligaciones de confidencialidad sobre las conversaciones, a fin

${ }^{126}$ En ese mismo sentido, Centro Nacional de Memoria Histórica. ;Basta ya! Colombia, cit., p. 21. 
de evitar que los temas sirvieran para hacer proselitismo; 2. Diálogos sin cese al fuego, para evitar que una tregua pudiera ser utilizada como una ventaja militar para soportar o escudarse de las ofensivas de las Fuerzas Armadas; 3. Conversaciones en el exterior, con el objetivo de evitar la constitución de zonas de retaguardia seguras para la guerrilla en el territorio nacional, y para reducir los riesgos de que el escenario de las negociaciones se convirtiera en una plataforma para hacer propaganda política a favor de la guerrilla.

El incremento notable y sostenido del gasto militar, durante los gobiernos de los presidentes Andrés Pastrana Arango, Álvaro Uribe Vélez y Juan Manuel Santos, que para 2013 llegaba a la cuota de 27 billones de pesos, ha terminado por afectar la estabilidad financiera del país. Gasto que se ha concentrado, sobre todo, en lograr mejoras en las labores de inteligencia, adquisición, mantenimiento y repotenciación de armamento militar, profesionalización de los combatientes de las Fuerzas Armadas y financiamiento de su operatividad. Entre 1998 y 2013 el $50 \%$ del presupuesto militar provino de impuestos especialmente aprobados para financiar el gasto de las Fuerzas Armadas, lo cual habla además de las dificultades envueltas en el sostenimiento continuo de los ritmos del gasto militar, particularmente cuando no se avizora que la dinámica de la guerra demande menos recursos. Se agrega la existencia de demandas contra la nación por la cifra de 214 billones de pesos, lo que en buena parte está asociado al sector defensa (en especial, relacionados con el problema pensional), ya que a 2013 el 51\% de las sumas pagadas por tales demandas correspondían a ese $\operatorname{sector}^{127}$.

\footnotetext{
${ }^{127}$ Fuente: Contraloría General de la República. "Un balance de la sostenibilidad de mediano plazo de la política de consolidación de paz, seguridad para la prosperidad y reparación de víctimas", Bogotá, documento no publicado, 2014.
} 
Los altos niveles del gasto militar han cumplido la función social manifiesta de recuperar unas condiciones básicas o esenciales de seguridad que se habían perdido, cuando quiera que derechos como el de la libertad, de movilidad y el derecho al trabajo, alcanzaron cotas considerables de perturbación o lesión. Empero, los muy altos niveles del gasto militar también han verificado la función social latente de distraer recursos indispensables para el desarrollo social y la reducción de las altas tasas de desigualdad que padece el país, además de tener un impacto directo en los fondos en manos de la población, que vía reformas tributarias fueron captados para el Estado, que en buena parte iban tener como destino la inversión en servicios y actividades productivas, irrigando la economía y generando empleo. 


\section{CONCLUSIONES}

Colombia tiene un Estado Social y Democrático de Derecho, el cual, otorga un papel preponderante a la participación ciudadana y a la democracia propiamente dicha.

Los principios, fundamentos y fines esenciales del Estado Social y Democrático de Derecho, solo es posible materializarlos o hacerlos efectivos en un Estado que garantice la Seguridad.

El concepto de fin puede ser entendido como los objetivos, metas, finalidades, propósitos planteados en las políticas, actuaciones, medidas, normas o instituciones, pertenece al mundo del deber ser.

En tanto la función social tiene que ver con las consecuencias sociales, los resultados, las secuelas, las repercusiones materiales que se ocasionan de la ejecución, aplicación, o la praxis de las actuaciones, políticas, medidas, normas o instituciones, pertenecen al ámbito del ser.

A partir de estas diferencias Germán Silva García e Iván F. Pacheco edifican un nuevo concepto de función social, el cual, es acogido en el presente trabajo y es entendido como "la comparecencia de consecuencias sociales de las que se puede derivar una abstracción teórica general que supone una significación social.”

Las funciones sociales se clasifican en manifiestan, latentes y simbólicas. 
En este trabajo se utilizó el método de Análisis Funcional, pues permite realizar el análisis de las Políticas Públicas de Seguridad del Estado, significa que admite determinar cuáles fueron los fines planteados, si fueron declarados o no declarados, y cuáles fueron las funciones sociales que se verificaron, es decir, si son manifiestas, latentes o simbólicas.

Como se ha puesto de presente, en particular a lo largo del último capítulo, las políticas de seguridad desarrolladas en los dos últimos gobiernos, de acuerdo con los lineamientos y el marco teórico del análisis funcional, han cumplido con varias funciones sociales.

Son tanto funciones sociales manifiestas, como latentes y simbólicas. De tal modo, es evidente que los fines de las políticas de seguridad de los dos últimos gobiernos, si bien se realizaron de manera eficaz en varios casos que aparecen representados en la constatación de las funciones manifiestas detectadas, en otros muchos casos plantearon una ruptura problemática respecto de las funciones sociales constatadas en sede de las políticas analizadas.

Así mismo, pese a los canales que permitieron una cierta continuidad entre la Política de Seguridad Democrática instaurada por el presidente Álvaro Uribe Vélez y la Política Integral de Seguridad y Defensa para la Prosperidad del presidente Juan Manuel Santos, sin duda, ha quedado demostrado que las funciones sociales verificadas son diferentes. 
Igualmente, se ha encontrado que muchas de las funciones sociales verificadas no sólo no son compatibles con el Estado Social y Democrático de derecho, sino que además contradicen o vulneran sus principios.

La contribución de este trabajo al desarrollo del conocimiento, es decir, aquello que en todo caso con modestia puede ser llamado "la tesis", conforme a lo expuesto en el capítulo final, previa construcción de un marco teórico en los dos primeros capítulos, ha radicado en la identificación y análisis de las funciones sociales que se han desprendido, como consecuencias sociales, de las políticas públicas en materia de seguridad de los dos últimos gobiernos.

Al lograr el cometido anterior, el método de análisis funcional ha demostrado su valor, es decir, su utilidad como mecanismo de análisis socio jurídico, en este caso, del derecho y de las políticas públicas.

A la luz de la lectura crítica derivada del análisis funcional de las políticas de seguridad las mismas deben ser replanteadas, de tal manera que por una parte coincidan con los principios del Estado Social y Democrático de Derecho y, por otro, logren una equivalencia con las finalidades declaradas para esas políticas. 


\section{BIBLIOGRAFÍA}

Agamben, Giorgio. Estado de Excepción, Buenos Aires, Adriana Hidalgo, 2003.

Aragón Reyes, Manuel. Constitución y Democracia, Madrid, Tecnos, 1989.

Bertalanffy, Ludwig von. Modern Theories of Development, New York, Oxford University, 1933.

Bobbio, Norberto. Contribución a la teoría del derecho, Madrid, Debate, 1990.

Bodin, Jean. Los seis libros de la república, México D.F., Fondo de Cultura Económica, 1986.

Carbonell, Miguel. Neoconstitucionalismo y derechos fundamentales, Quito, Cevallos. 2010.

Carvajal Martínez, Jorge Enrique. La Seguridad Dentro del Estado de Garantías, Bogotá, ILSA, 2008.

Centro Nacional de Memoria Histórica. ;Basta ya! Colombia: memorias de guerra y dignidad, Bogotá, Centro Nacional de Memoria Histórica y República de Colombia DPS, 2013.

Clausewitz, Karl von. De la guerra, Barcelona, Mateu, 1972. 
Corte Constitucional, Sentencia T-525 de 1992, Magistrado Ponente Ciro Angarita Barón.

Corte Constitucional. Sentencia C - 449 de 1992, Magistrado Ponente Alejandro Martínez Caballero.

Corte Constitucional. Sentencia T - 406 de 1992, Magistrado Ponente Ciro Angarita Barón.

Corte Constitucional. Sentencia No. T-571 de 1992, Magistrado Ponente Jaime Sanín Greiffenstein.

Corte Constitucional. Sentencia T-505 de 1992, Magistrado Ponente Eduardo Cifuentes Muñoz.

Corte Constitucional. Sentencia T - 426 de 1992, Magistrado Ponente Eduardo Cifuentes Muñoz.

Corte Constitucional. Sentencia T-102 de 1993, Magistrado Ponente Carlos Gaviria Díaz.

Corte Constitucional. Sentencia C - 566 de 1995, Magistrado Ponente Eduardo Cifuentes Muñoz.

Corte Constitucional. Sentencia T-513 de 1995, Magistrado Ponente Vladimiro Naranjo Mesa.

Corte Constitucional. Sentencia C-456 de 1997, Magistrados Ponentes Jorge Arango Mejía y Eduardo Cifuentes Muñoz. 
Corte Constitucional. Sentencia SU - 111 de 1997, Magistrado Ponente Eduardo Cifuentes Muñoz.

Corte Constitucional. Sentencia C- 1064 de 2001, Magistrado Ponente Manuel José Cepeda Espinosa y Jaime Córdoba Triviño.

Corte Constitucional. Sentencia C - 107 de 2001, Magistrada Ponente Clara Inés Vargas Hernández.

Corte Constitucional. Sentencia C- 1064 de 2002, Magistrado Ponente Manuel José Cepeda Espinosa y Jaime Córdoba Triviño.

Corte Constitucional. Sentencia SU - 636 de 2003. Magistrado Ponente Jaime Araujo Rentería.

Corte Constitucional. Sentencia C - 579 de 2013, Magistrado Ponente Jorge Ignacio Pretelt Chaljub.

Coser, Lewis. Las funciones del conflicto social, México D.F., Fondo de Cultura Económica, 1961.

Cotterrell, Roger. Introducción a la sociología del derecho, Barcelona, Ariel, 1991. 
Ferrajoli, Luigi. "El derecho penal mínimo", en Prevención y teoría de la pena, Santiago de Chile, Jurídica Cono Sur, 1995.

Ferrajoli, Luigi. Derecho y razón, $2^{a}$ ed., Madrid, Trotta, 1997.

Ferrajoli, Luigi. Poderes Salvajes. La crisis de la democracia constitucional, Madrid, Trotta 2011.

Ferrari, Vincenzo. Funciones del derecho, Madrid, Debate, 1989.

Ferrari, Vincenzo. Acción jurídica y sistema normativo. Introducción a la sociología del derecho, Madrid, Universidad Carlos III de Madrid y Dykinson, 2000.

Ferrari, Vincenzo. Derecho y sociedad. Elementos de sociología del derecho, Bogotá, Universidad Externado de Colombia, 2006.

Gusfield, Joseph R. Contested Meanings: the Construction of Alcohol Problems, Madison, Wisconsin University, 1996.

Guzmán, Germán, Orlando Fals Borda y Eduardo Umaña Luna. La Violencia en Colombia, $2^{\mathrm{a}}$ ed., T. I, Bogotá, Tercer Mundo, 1963.

Hernández Becerra, Augusto. Las ideas políticas en la historia, Bogotá, Universidad Externado de Colombia, 1997. 
Ibáñez Najar, Jorge Enrique. Seguridad Nacional, seguridad del Estado y seguridad ciudadana: una aproximación jurídica, Bogotá, Universidad Sergio Arboleda, 2005.

Lafáurie Rivera, José Félix. Posconflicto y Desarrollo, Bogotá, FEDEGAN, 2006.

Merton Robert K. Teoría y estructura sociales, $3^{\mathrm{a}}$ ed., México D.F., Fondo de Cultura Económica, 1992.

Molano, Alfredo. Amnistía y violencia, Bogotá, CINEP, 1978.

Pacheco, Iván F. "El método de análisis funcional en la criminología”, en Carlos Elbert (Coord.), La criminología del siglo XXI en América Latina, Buenos Aires, Rubinzal -Culzoni, 1999.

Parsons, Talcott. El sistema social, $2^{\mathrm{a}}$ ed., Madrid, Alianza Universidad, 1984.

Pecaut, Daniel. "Reflexiones sobre el fenómeno de La Violencia", en Once ensayos sobre La Violencia, Bogotá, CEREC y Centro Gaitán, 1985.

Pecaut, Daniel. Orden y violencia: Colombia 1930-1954, Vol. II, Bogotá, CEREC y Siglo XXI, 1987.

Pérez Escobar, Jacobo. Derecho constitucional colombiano, 5ª ed., Bogotá, Temis, 1997. 
Pérez Royo, Javier. Curso de derecho constitucional, $2^{\mathrm{a}}$ ed., Madrid, Marcial Pons, 1995.

Pisarello, Gerardo. La ofensiva oligárquica y la lucha por la constitución democrática. Un largo termidor. La ofensiva del constitucionalismo antidemocrático, Madrid, Trotta, 2011.

Ramírez Tobón, William. Estado, violencia y democracia, Bogotá, Tercer Mundo e IEPRI.

Ritzer, George. Teoría sociológica contemporánea, $3^{\text {a }}$ ed., Madrid, McGraw Hill, 1993.

Rozo Acuña, Eduardo. Introducción a las instituciones políticas. Bogotá, Gustavo Ibáñez, Sexta edición, 1998.

Sáchica, Luis Carlos. Derecho Constitucional General, Bogotá, Temis, 1999.

Salazar, Ana María. Seguridad Nacional Hoy: el reto de las democracias, México D.F., Punto de Lectura, 2008.

Sánchez, Gonzalo y Donny Meertens. Bandoleros, gamonales y campesinos, $3^{\text {a }}$ ed., Bogotá, El Áncora, 1985.

Sánchez Ferriz, Remedios. Introducción al Estado Constitucional, Barcelona, Ariel, 1993. 
Sandoval Huertas, Emiro. Penología. Parte especial, Bogotá, Universidad Externado de Colombia, 1984.

Silva García, Germán. "Delito político y narcotráfico”, en La problemática de las drogas. Mitos y realidades, Bogotá, Universidad Externado de Colombia y Programa "Enlace” del Ministerio de Comunicaciones, 1998.

Silva García, Germán. Criminología. Teoría sociológica del delito, Bogotá, ILAE, 2011.

Silva García, Germán. "La décima es la vencida. El nuevo proceso de paz con las FARC”, en Nueva Época, No. 39, Bogotá Universidad Libre, 2012.

Sutherland, Edwin H. Principles of Criminology, $3^{\mathrm{a}}$ ed., Philadelphia, J.B. Lippincott, 1939.

Szabo, Denis. Criminología y política en materia criminal, México D.F., Siglo XXI, 1980.

Treves, Renato. Introducción a la sociología del derecho, Madrid, Taurus, 1985.

Valencia Villa, Alejandro. La humanización de la guerra, Bogotá, Tercer Mundo y Uniandes, 1992.

Velásquez Gavilanes, Raúl. "Hacia una nueva definición del concepto de "política pública”, en Desafíos, No. 20, Bogotá, 2009. 
Velásquez Turbay, Camilo. Derecho constitucional, Bogotá, Universidad Externado de Colombia, 1998.

Verdú, Paolo Lucas. Estado Liberal Derecho y Estado Social de Derecho. T. II, Universidad de Salamanca, 1955.

Verdú, Pablo Lucas. Curso de derecho político. Madrid, Tecnos, 1984.

Weber, Max. Economía y sociedad, 2ª ed., México D.F., Fondo de Cultura Económica, 1992.

Zagrebelsky, Gustavo, El derecho dúctil, Madrid, Trotta. 1995. 


\section{DOCUMENTOS:}

Contraloría General de la República. "Un balance de la sostenibilidad de mediano plazo de la política de consolidación de paz, seguridad para la prosperidad y reparación de víctimas", Bogotá, documento no publicado, 2014.

“Libertad y Orden”, consultado en marzo de 2014 en la página Web www.mindefensa.gov.co.

“Manifiesto Democrático” de 2002. 